Florida International University

FIU Digital Commons

$11-16-2017$

\title{
Paleoenvironments, origin, and relative maturity of organic matter in Barremian-Aptian limestones of the eastern Prada Quarry, Organyà Basin, NE Spain
}

Jose R. Llaguno

Florida International University, jllag003@fiu.edu

Follow this and additional works at: https://digitalcommons.fiu.edu/etd

Part of the Physical Sciences and Mathematics Commons

\section{Recommended Citation}

Llaguno, Jose R., "Paleoenvironments, origin, and relative maturity of organic matter in Barremian-Aptian limestones of the eastern Prada Quarry, Organyà Basin, NE Spain" (2017). FIU Electronic Theses and Dissertations. 3510.

https://digitalcommons.fiu.edu/etd/3510

This work is brought to you for free and open access by the University Graduate School at FIU Digital Commons. It has been accepted for inclusion in FIU Electronic Theses and Dissertations by an authorized administrator of FIU Digital Commons. For more information, please contact dcc@fiu.edu. 


\title{
FLORIDA INTERNATIONAL UNIVERSITY
}

Miami, Florida

\section{PALEOENVIRONMENTS, ORIGIN, AND RELATIVE MATURITY OF ORGANIC MATTER IN BARREMIAN-APTIAN LIMESTONES OF THE EASTERN PRADA QUARRY, ORGANYÀ BASIN, NE SPAIN}

\author{
A thesis submitted in partial fulfillment of \\ the requirements for the degree of \\ MASTER OF SCIENCE \\ in \\ GEOSCIENCES \\ by \\ Jose Raul Llaguno \\ 2017
}


To: Dean Michael R. Heithaus

College of Arts, Sciences, and Education

This thesis, written by Jose Raul Llaguno, and entitled Paleoenvironments,

Origin, and Relative Maturity of Organic Matter in Barremian-Aptian

Limestones of the Eastern Prada Quarry, Organyà Basin, NE Spain,

having been approved in respect to style and intellectual content, is referred

to you for judgment.

We have read this thesis and recommend that it be approved.

Laurel Collins

Grenville Draper

Florentin Maurrasse, Major Professor

Date of Defense: November 16, 2017

The thesis of Jose Raul Llaguno is approved.

Dean Michael R. Heithaus

College of Arts, Sciences and Education

Andrés G. Gil

Vice President for Research and Economic Development and Dean of the University Graduate School

Florida International University, 2017 


\section{DEDICATION}

To Yarina, my dear wife, whose dedication for me and our children made it possible for me to complete this work, and to our three children, Kevin, Kirsten, and Karen, who are the most precious gifts from above. To Mimi, for being my rock, and for always believing in me. 


\section{ACKNOWLEDGEMENTS}

I would like to express my heartfelt gratitude to my advisor Dr. Florentin J-M. R. Maurrasse for his unwavering intellectual, moral, and financial support through these past years. Not only did I benefit immensely from his teachings in geosciences and recommended readings with his contagious scientific enthusiasm, but his forthright approach to life has indelibly made an everlasting positive impact in many areas of my life. It is privilege to be associated with you Dr. Maurrasse.

I am very thankful to Dr. Laurel Collins and Dr. Grenville Draper, my committee members, for their invaluable observations, corrections, and suggestions whilst developing this work and for allowing me to use their laboratories. I am very grateful to Dr. Tatiana Trejos and Dr. Sarah Jantzi for their training in LA-ICPMS processes and data integration for trace element analyses. My kind thanks to Dr. Cesar Ramirez for his contribution on producing chromatographs for biomarker analyses. Many thanks to Dr. Peter Swart from the Rosenstiel School of Marine and Atmospheric Science (RSMAS), University of Miami laboratory for stable isotope analyses. In addition, I would like to recognize my fellow student Jander Socorro for his genuine and unconditional support both as a friend and as colleague. My special thanks to Diane Pirie for her help and efficiency in keeping the laboratory facilities in working order; to Thomas Beasley for always making himself available for SEM with EDS microscopy analysis for us. 


\begin{abstract}
OF THE THESIS
PALEOENVIRONMENTS, ORIGIN, AND RELATIVE MATURITY OF ORGANIC

MATTER IN BARREMIAN-APTIAN LIMESTONES OF THE EASTERN PRADA

QUARRY, ORGANYÀ BASIN, NE SPAIN
\end{abstract}

by

Jose Raul Llaguno

Florida International University, 2017

Miami, Florida

Professor Florentin Maurrasse, Major Professor

This study is a multi-proxy analysis of a 30-m section of a Barremian-Aptian succession of interbedded, grayish black (N2) and black (N1) limestones from a quarry of the Sierra de Prada. Index taxa include planktic foraminifera Globigerinelloides blowi and Hedbergella sigali, which combined with $\delta^{13} \mathrm{C}$ data from Cresmina and Gorgo a Cerbara sections indicate a late Barremian to early Aptian age. The rocks are organic-rich with 0.67 - $3.10 \mathrm{wt} \%$ total organic carbon (TOC). A marlstone interval $(\sim 1 \mathrm{~m})$ at $2.24 \mathrm{~m}$ has a low bioturbation index (1), TOC $\sim 6.66 \mathrm{wt} \%$, framboidal pyrite, and enrichment spikes of major, biolimiting, and redox-sensitive trace elements ( $\mathrm{Al}, \mathrm{Si}, \mathrm{Ti}, \mathrm{P}, \mathrm{Fe}$, and $\mathrm{Mo}, \mathrm{Cr}, \mathrm{Cu}, \mathrm{V}, \mathrm{Th}$ ), indicating an anoxic episode. Biomarker analyses show a predominance of $n$-alkanes $(\leq \mathrm{nC} 20)$ at this level, suggesting an in situ origin of organic matter from phytoplankton. Pr/Phy ratios below 2 imply that organic matter did not reach overmaturity. 


\section{TABLE OF CONTENTS}

CHAPTER $\quad$ PAGE

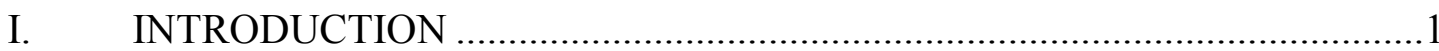

Mid-Cretaceous Global Conditions ....................................................1

Project Objectives and Hypothesis .....................................................2

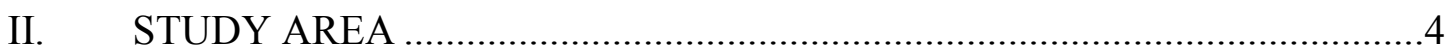

Geographic Location.....................................................................

Prada Formation.............................................................................

Regional Lithostratigraphy ...........................................................

Outcrop Description..............................................................................

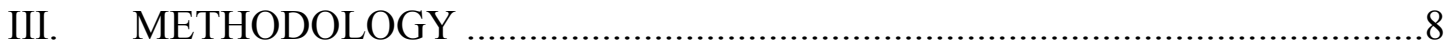

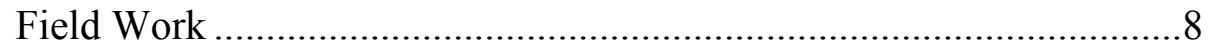

Petrographic Analysis ...............................................................

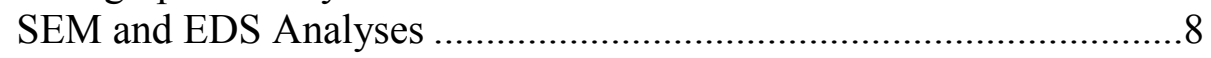

Total Carbon/Carbonate-TC, TOC, TIC ..............................................9

Biomarker Analysis ...........................................................................11

Redox Sensitive Trace Elements .....................................................12

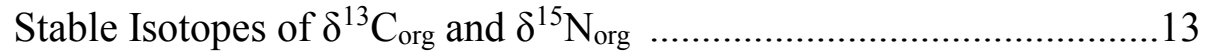

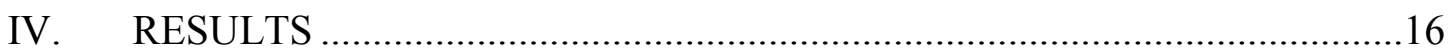

Petrographic Analysis ....................................................................16

SEM and EDS Analyses ...............................................................17

Total Carbon/Carbonate-TC, TOC, TIC .............................................18

Biomarker Analysis ………………………….............................18

Redox Sensitive Trace Elements .....................................................19

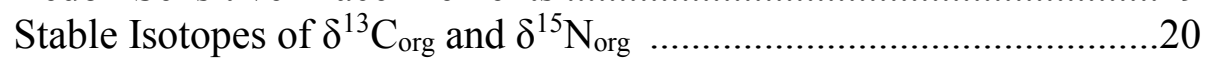

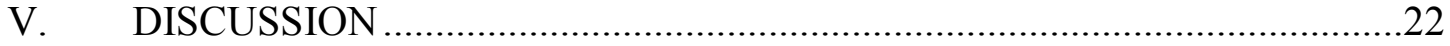

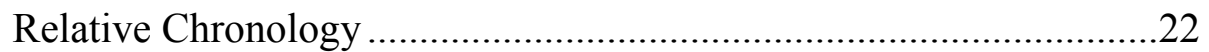

Paleoenvironments / Lithofacies.......................................................24

Chemostratigraphy / Elemental Content ..............................................25

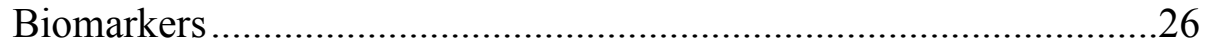

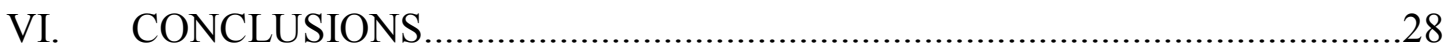

Recommendations for Future Research ...........................................29

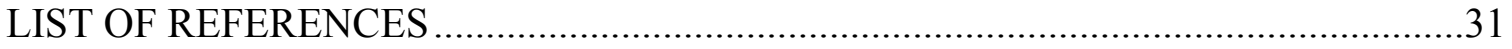

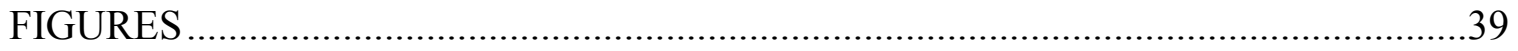




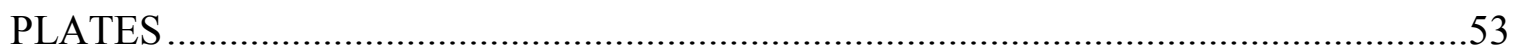

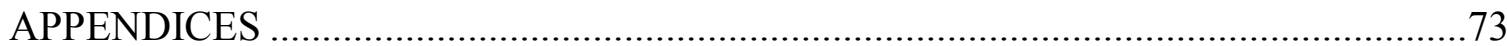




\section{LIST OF FIGURES}

FIGURE

PAGE

Figure 1. Paleogeographic reconstruction of the Tethyan realm during the midCretaceous at $\sim 115 \mathrm{Ma}$. Asterisks mark location of Cresmina, Gorgo a Cerbara, and Prada Quarry sections. Map taken from Burla et al. (2008), originally from Masse et al. (2000).

Figure 2. Geological map of the Pyrenees including location of Organyà Basin.

Modified after Vissers et al., (2016).

Figure 3. Sierra de Prada: south flank showing position of Prada Quarry. Quarry accessible off the road leading to the municipal skydiving platform (Envol Organyá) on the south flank of the Sierra de Prada overlooking the Cabó River valley. Google Earth images dated 31 Dec. 2008.

Figure 4. A) Field view of the upper $15 \mathrm{~m}$ of the eastern Prada Quarry section showing the beds dipping southward which allowed to easily follow the superposition of the succession along the quarry cut. B) View of sampling interval marked by orange tape shows nature of beds within lower $1 \mathrm{~m}$ (sediment thickness)

Figure 5. A) Stratigraphic column of the lower Cretaceous of the Organyà Basin (modified from García-Senz, 2002), as proposed by Sanchez-Hernandez and Maurrasse, (2014). B) Chronostratigraphic column of the $30 \mathrm{~m}$ studied at the Prada Quarry with lithologic characterization. Facies studied in the Prada Quarry section correspond to the mudstone classification of Dunham (1962).

Figure 6. Image of a silicified lens observed at the $16.45 \mathrm{~m}$ level stratigraphic level of the Prada Quarry section (CC-15-45). Hammer for scale (blue handle length $15 \mathrm{~cm})$.

Figure 7. SEM images of two different specimens of Hedbergella sigali Moullade 1966 obtained from sample CC-15-18. Scale bar 100 microns where not specified..

Figure 8. SEM images obtained from thin section of sample CC-15-05 illustrate a significant contribution of disaggregated nannoconids fragments to the matrix 
Figure 9. SEM/EDS elemental diagrams of analyses performed on thin sections of the Prada Quarry section showing qualitative composition of red square areas of samples: (A) Sample CC-15-04. (B) Sample CC-15-05. (C) Sample CC-15-12 (D) Sample CC-15-18. The texture of the fine matrix and the isotropic distribution of grains are seen in micrographs on backscattered electron mode (BSE)

Figure 10. Chemostratigraphy of the Prada Quarry section showing temporal variations in: TIC, TOC, Carbon and Nitrogen isotope values. Light grey bands indicate positive correlation between TOC, Carbon and Nitrogen isotopes versus TIC. Red dashed lines representing background values are plotted for reference

Figure 11. Lithostratigraphy of the Prada Quarry section and chromatographs of molecular biomarkers $n$-alkane distribution measured in 3 samples corresponding to different levels. Compounds exhibiting carbon chain lengths $>20$ indicate OM from terrestrial origin incorporated to the basin. Compounds with lengths $<20$ indicate in situ origin of OM from phytoplankton.

Figure 12. Chemostratigraphic diagram including, major and biolimiting Elements of the Prada Quarry section and their concentrations in ppm ( $\mathrm{Si}$ in parts per thousand). Red dashed lines included show background levels...

Figure 13. Chemostratigraphic diagram including, redox-sensitive trace elements of the Prada Quarry section and their concentrations in ppm. Red dashed lines are plotted to indicate background levels.

Figure 14. Carbon isotope correlation based on data for three sections. From left to right Cresmina section from the North Atlantic (Burla et al., 2003); Prada Quarry section from the Organyà Basin (Tethys) (this study); and, Gorgo a Cerbara section (Tethys) (Stein et al., 2011). Asterisks (3) show common data points at positive shifts in the $\delta^{13} \mathrm{C}$ curves used for correlation. Segment boundaries (red dashed lines) are established by inflection patterns and/or changing gradients of the carbon isotope curve that show distinct trends allowing approximate correlation 


\section{LIST OF PLATES}

PLATE

PAGE

Plate 1. Microphotographs of facies of the Prada Quarry section corresponding to different stratigraphic levels.

Plate 2. Microphotographs of slides CC-15-09 and CC-15-38.

Plate 3. SEM images of benthic and planktic foraminifera obtained from sample CC-15-18

Plate 4. SEM images of foraminifera obtained from sample CC-15-18

Plate 5. SEM images of organisms and biogenic fragments obtained from sample CC-15-18, CC-15-50, and CC-15-63

Plate 6. Microphotographs of slides CC-15-49, CC-15-63, CC-15-64, and $\mathrm{CC}-15-65$.

Plate 7. Microphotographs of slide CC-15-64

Plate 8. Microphotographs of slides CC-15-12, CC-15-33, CC-15-39, CC-15-43, and CC-15-50

Plate 9. SEM images of specimens, biogenic and non-biogenic fragments

CC-15-18, CC-15-42, CC-15-58, and CC-15-63

Plate 10. Microphotographs of slides CC-15-03, CC-15-05, and CC-15-50. 


\section{INTRODUCTION}

\section{Mid-Cretaceous Global Conditions}

The Jurassic and Cretaceous Periods recorded numerous oceanic anoxic events (OAEs) (Schlanger and Jenkyns, 1976; Jenkyns, 1980) during a time of pronounced greenhouse conditions. Major paleoceanographic and tectonic changes, including the emplacement of Large Igneous Provinces (Larson, 1991; Stinton and Duncan, 1997; Kerr, 1998; Larson and Erba, 1999) that developed in the latest Barremian - early Aptian (Ontong Java-Manihiki and Nova-Canton Trough) have been discussed as contributing factors to the strenuous conditions that preceded and prevailed during the prominent early Aptian Anoxic event 1a (OAE1a) (Erba, 2004; Li et al., 2008; Sanchez-Hernandez and Maurrasse, 2014, 2016).

During Cretaceous time a pulse of rapid sea floor spreading was accompanied by a volume increase of the mid-ocean ridge system (Hays and Pitman, 1973), leading to a major transgression of the sea over the low-lying coastal plains (Schlanger and Jenkyns, 1976). This transgression resulted in the formation of $35 \times 10^{6} \mathrm{~km}^{2}$ new epicontinental seas less than $300 \mathrm{~m}$ deep in addition to the already existing $33 \times 10^{6} \mathrm{~km}^{2}$ between the Barremian-Aptian and Cenomanian-Turonian times (Fig. 1) (Schlanger and Jenkyns, 1976). Under these climatic and hypsographic conditions, organic carbon production per year in the world oceans increased, and the amount of $\mathrm{O}_{2}$ renewal in bottom waters decreased, therefore enabling worldwide vertical and horizontal expansion of thick, widespread $\mathrm{O}_{2}$ minimum zones (Schlanger and Jenkyns, 1976).

The development of restricted epicontinental seas and reduced ocean ventilation as a result of decreased oceanic circulation led to the stagnation of deep-water masses 
(Bralower et al., 1994; Sanchez-Hernandez and Maurrasse, 2014) thus resulting in unique oxygen-depleted conditions that produced widespread distribution of organic-rich sediments.

An extensive literature exists on the early Aptian Anoxic event 1a (OAE1a) event, but the paleoenvironmental transition between prevailing conditions in the latest Barremian to the early Aptian (Mutterlose and Böckel, 1998; Godet et al., 2008; Mutterlose et al., 2009; Stein et al., 2011, 2012; Pauly et al., 2013, Sanchez-Hernandez and Maurrasse, 2014) remain to be further investigated. Hence, the mechanisms associated with this transition, including environmental and biological responses to changing conditions preceding OAE1a, are the subject of the present study.

\section{Project Objectives and Hypothesis}

Previous studies estimated the relative chronostratigraphic position of the $30 \mathrm{~m}$ section studied to be part of the Prada Formation, and falls approximately in the time interval of the latest Barremian, possibly the earliest Aptian (Berástegui et al., 1990; Caus et al., 1990; Bernaus, 1998; Garcia-Senz, 2002; Bernaus et al., 2003; Sanchez-Hernandez and Maurrasse, 2014, 2016; Socorro et al., 2017). Although that time interval does not include a known oceanic anoxic event in the Tethyan domain (Fig. 1), given the black color of the rock sequence, and based on former results from these studies (supra), I hypothesize that the semi-restricted Organyà Basin (Fig. 2) (Garcia-Senz, 2002; Sanchez-Hernandez and Maurrasse, 2014, 2016; Socorro et al., 2017) developed prevalent oxygen-deficient conditions that produced black limestones locally with enhanced organic matter (OM) production and preservation prior to the onset of Oceanic Anoxic Event 1a (OAE1a). 
The objective of this study is to use multiple proxies, including detailed petrographic analysis, total inorganic carbon (TIC), total organic carbon (TOC), stable isotopes, redox sensitive trace elements (RSTEs), and biomarkers to provide supporting evidence to characterize the sedimentological and geochemical record in the sequence at that time. The results will permit a better understanding of the temporal depositional evolution of this interval of the Organyà Basin deposits, and further shed light on the conditions preceding the Aptian Anoxic event 1a (OAE1a) in the basin. 


\section{STUDY AREA}

\section{Geographic Location}

The section studied $\left(42^{\circ} 13^{\prime} 45.00^{\prime \prime} \mathrm{N}, 1^{\circ} 19^{\prime} 38^{\prime \prime} \mathrm{E}\right)$ is located on the southern flank of the easternmost area of the Sierra de Prada (Fig. 3) which consists of sediments accumulated in the Organyà Basin (Fig. 2) that is now exposed in the uppermost unit of the Bòixols Thrust Sheet (Berástegui et al., 1990; Caus et al., 1990; Bernaus et al., 2003; García-Senz, 2002; Sanchez-Hernandez and Maurrasse, 2014, 2016).

The studied section consists of 30 m thick grayish black (N2) and black (N1) (Goddard et al., 1963) limestones, which are accessible within an abandoned limestone quarry (Fig. 4) off the road leading to the municipal skydiving platform (Envol Organyá) on the south flank of the Sierra de Prada (Fig. 3) overlooking the Cabó River valley.

\section{Prada Formation}

Mey et al. (1968) formally described the Prada Formation which they named after the Sierra de Prada, a limestone mountain ridge west of the Segre River (Fig. 3) and consists of limestones of the Organyà Basin sediments (Berástegui et al., 1990; Caus et al., 1990; García-Senz, 2002; Bernaus, et al., 2003). The Prada Formation has been assigned an

overall latest Barremian to early Aptian age, based on paleontological studies of ammonites, and benthic and planktic foraminifera (Peybernès and Souquet, 1973; Peybernès, 1976; Martínez, 1982; Caus et al., 1990; Berástegui et al., 1990; Bachmann and Willems, 1996; Bernaus et al., 2002, 2003). The Prada Formation underlies the organicrich Cabo Marls, or Cabo Formation (García-Senz, 2002), where previous studies of the El Pui section by Sanchez-Hernandez and Maurrasse, $(2014,2016)$ place the Early Aptian 
Oceanic Anoxic Event OAE1a in the sequence of sediments of the Organyà Basin (Garcia Senz, 2002; Sanchez-Hernandez and Maurrasse, 2016; Socorro et al., 2017).

Approximately $4000 \mathrm{~m}$ of Lower Cretaceous marine sediments (Fig. 5) accumulated in a semi-restricted pull-apart basin that developed in the northern part of the Iberian Peninsula (Fig. 1) during extensional processes associated with the opening of the Bay of Biscay (Berástegui et al., 1990). The basin lasted about 38 million years: Upper Kimmeridgian to Albian, and compressional movements during the latest Cretaceous to middle Miocene caused emergence of the basin in one of the series of the Pyrenean foldand-thrust belt (Muñoz, 1991; Muñoz et al., 1992; Golonka, 2004). In the present geologic setting, the internal arrangement of the sedimentary sequence deposited in the Organyà Basin (Fig. 2) consists of an E-W asymmetric syncline (Santa Fe syncline) exhibiting various differences in thickness between the two flanks. The difference in thickness between the southern and northern limb of the basin is reported as a syn-depositional asymmetry (Bernaus et al., 2003). An E-W transversal section of the basin reveals an overall geometry possibly controlled by transverse or oblique basement faults (Berástegui et al., 1990; Bernaus et al., 2003).

The Eastern Prada quarry section (Fig. 4) was selected because of its easy access, and potential to include strata between the uppermost Barremian and lower Aptian (Fig. 5).

\section{Regional Lithostratigraphy}

Previous studies of the sedimentary deposits of the Organyà Basin (Fig. 2) (Peybernès and Souquet, 1973; Peybernès, 1976; Caus et al., 1990; Berástegui et al., 1990; Garcia-Senz, 2002; Bernaus et al., 2003; Sanchez-Hernandez and Maurrasse, 2014; 2016) have shown that its stratigraphic evolution was largely controlled by the high rate of 
accumulation coincident with high rate of subsidence modulated by eustatic fluctuations in sea level (Bernaus et al., 2003), hence about $1100 \mathrm{~m}$ of limestone and marlstone accumulated in approximately $5 \mathrm{Ma}$.

The Prada sequence (Fig. 5) is reported to comprise a series of transgressive regressive carbonates (Berástegui et al., 1990; Garcia-Senz, 2002; Bernaus, et al., 2003), including two main facies associations as follows:

1) Lower packstones to bioclastic-oolitic grainstones with beige-ochre to grey color composed of ooids, bivalves, echinoids, bryozoans, gastropods, serpulids, corals, benthic foraminifers (Bernaus, et al., 2003). Common internal structures are cross-laminae and cross-stratification: Hence, it has been interpreted as a deposit of a high energy shoal environment (Berástegui et al., 1990; Garcia-Senz, 2002; Bernaus, et al., 2003).

2) Upper dark grey mudstones to packstones with bioclasts that consist of Charophytes and Orbitolinids, including few ostracods, rare small thin-walled milliolids, bivalves, echinoids, benthic foraminifers, and annelids (Caus et al., 1990; Bernaus, et al., 2003). As reported by Rosell and Llompart, 1982 three facies or packages can be noted from bottom to top: distinct beds that are rich in agglutinated foraminifera while others that are rich in charophytes, barren mudstones, and lignitiferous marls at the top (Berástegui et al. 1990). These beds have been interpreted as deposits from lagoonal and shoal environments (Bernaus et al., 2003).

\section{Outcrop Description}

The present study comprises a section of well-exposed, dark gray (N7) to grayish black (N2) and black (N1) (Goddard et al., 1963) micritic limestones and marlstone with beds varying in thickness from $\sim 3 \mathrm{~cm}$ to $80 \mathrm{~cm}$ (Fig. 4). At the field scale, a horizon with 
silicified lenses is observed at the $16.45 \mathrm{~m}$ level (Fig. 6). The homoclinal structure showing the beds dipping southward allowed to easily follow the superposition of the succession along the quarry cut approximately perpendicular to the fold axis. 


\section{METHODOLOGY}

\section{Field Work}

Field work was carried out for 6 days (24-30 November 2015) at the outcrops to systematically measure and sample different accessible beds with a sampling strategy of collecting 1 sample per $\sim 50 \mathrm{~cm}$ interval. Given the overall thickness of sediments accumulated in the basin over a duration of 38 million years the dry bulk accumulation rate would fall around $10.52 \mathrm{~cm} / \mathrm{ky}$. Thus, the sampling interval is sufficiently close to provide data that will allow to further understand sedimentary characteristics, depositional signals, and conduct a high-resolution study (Fig. 4). Sixty-seven (67) samples were collected from a 30-m segment of the section in the eastern Prada Quarry.

\section{Petrographic Analysis}

One thin section was made per sample for petrographic analysis, and eight (8) smear slides were made in less indurated beds in order to detect the presence of calcareous nannofossils in the fine matrix. Petrographic and microfacies analyses have been conducted on all samples with conventional transmitted and polarized light microscopy (Olympus BH-2 microscope).

\section{SEM and EDS Analyses}

SEM analyses were performed at Florida International University in the Florida Center for Analytical Electron Microscopy (FCAEM) using a JEOL JSM 5910LV scanning electron microscope with an EDAX energy dispersive spectroscope. Energy dispersive spectroscopy (EDS) was performed on four (4) samples to investigate the makeup of the rock matrix. 
Sample preparation for the analyses included carbon coating to (150 A) thickness, and processing in Compo mode under backscattered electron imaging detection (BSE). Areas of the slide targeted for investigation were first determined and inspected in secondary electron imaging (SEI), and later switched to backscatter (BSE) mode for qualitative elemental analysis. Specimens and bioclasts for SEM examination and imaging were coated using a Gold/Palladium target with purpose of reducing surface charging while improving conductivity.

\section{Total Carbon/Carbonate - TC, TOC, TIC}

Weight percent total inorganic and organic carbon contents (percentages) were measured in 67 samples at Florida International University (FIU) by means of loss on ignition (LOI). All LOI analyses were carried out in a Barnstead Thermolyne ${ }^{\circledR}$ muffle furnace F62700 with digital temperature display and controlled by a microprocessor with a type K Chromel/Alumel Thermocouple ${ }^{\circledR}$. Care was taken that no particles and humidity persisted in samples before weighing. Therefore, before any measurement was made empty crucibles were washed with Alconox ${ }^{\circledR}$ and rinsed with tap water, then submerged overnight in a $10 \% \mathrm{HCL}$ solution and rinsed 4 times with deionized water. Afterwards, the empty crucibles were heated in the muffle oven for $1 \mathrm{~h}$ at $560{ }^{\circ} \mathrm{C}$ and placed in a desiccator overnight. Wet sediment was oven-dried at $105^{\circ} \mathrm{C}$ overnight and all samples were cooled to room temperature and immediately placed in a desiccator.

The LOI method is based on sequential heating of the samples in a muffle furnace as proposed by Heiri et al., 1999. The powdered sediment sample $(0.3 \mathrm{~g})$ was first oven-dried for $\sim 18 \mathrm{~h}$ to constant weight at around $105{ }^{\circ} \mathrm{C}$; then organic matter was combusted in an 
initial step to ash and carbon dioxide at a temperature of $550^{\circ} \mathrm{C}$ for 2 hours. The LOI was then calculated using the following equation (1):

(1) $\quad \mathrm{LOI}_{550}=\left(\left(D W_{105}-D W_{550}\right) / D W_{105}\right) * 100$

$\mathrm{LOI}_{550}$ represents $\mathrm{LOI}$ at $550{ }^{\circ} \mathrm{C}$ (as \%), $\mathrm{DW}_{105}$ represents the dry weight $(\mathrm{g})$ of the sample before combustion and $\mathrm{DW}_{550}$ the dry weight $(\mathrm{g})$ of the sample after heating to 550 ${ }^{\circ} \mathrm{C}$. The weight loss should then be proportional to the amount of organic carbon contained in the sample (Dean, 1974).

The second step entailed exposure at $950{ }^{\circ} \mathrm{C}$ for 2 hours, where carbon dioxide diffuses from calcium carbonate, leaving calcium oxide. The LOI was calculated using equation (2) as:

\section{(2) $\quad L O I_{950}=\left(\left(D W_{550}-D W_{950}\right) / D W_{105}\right) * 100$}

where $\mathrm{LOI}_{950}$ is the $\mathrm{LOI}$ at $950{ }^{\circ} \mathrm{C}$ (as a percentage), $\mathrm{DW}_{550}$ is the dry weight of the sample after combustion of organic matter at $550{ }^{\circ} \mathrm{C}, \mathrm{DW} 950$ represents the dry weight of the sample after heating to $950^{\circ} \mathrm{C}$, and $\mathrm{DW}_{105}$ is the initial dry weight of the sample before the organic carbon combustion (all in grams).

Assuming a weight of $44 \mathrm{~g} \mathrm{~mol}^{-1}$ for carbon dioxide and $100 \mathrm{~g} \mathrm{~mol}^{-1}$ for calcium carbonate $\left(\mathrm{CaCO}_{3}\right)$ ratio $(100 / 44=2.27)$, the weight loss by LOI at $950{ }^{\circ} \mathrm{C}$ multiplied by 2.27 should then theoretically equal the weight of the calcium carbonate in the original sample (Bengtsson \& Enell, 1986).

For this study, LOI temperatures implemented were close to those proposed by Dean (1974) and Bengtsson \& Enell (1986), i.e. $550{ }^{\circ} \mathrm{C}$ for organic matter and $950{ }^{\circ} \mathrm{C}$ for calcium carbonate as proposed by Heiri et al., 1999. 
TIC/TOC are expressed as $\mathrm{CaCO}_{3}$ and $\mathrm{C}$-wt $\%$ respectively of bulk sediment. TIC values are used to assign a lithologic classification based on the nomenclature adopted in our sedimentary laboratory (Gaona-Narvaez et al., 2013a, 2013b; Sanchez-Hernandez and Maurrasse, 2014, 2016, Socorro et al., 2017). Hence, the relative percentage of total measured $\mathrm{CaCO}_{3}$ (TIC) indicates: limestone, $\leq 65 \% \mathrm{CaCO}_{3}$; marlstone, $30-60 \%$ (SanchezHernandez and Maurrasse, 2014).

\section{Biomarker Analysis}

Biomarkers ( $n$-alkanes) were analyzed from 28 samples following the analytical technique of our laboratory facility (Socorro et al., 2017), which is a modified version of the method used mainly onboard research drilling vessels of the International Ocean Discovery Program (IODP). Based on personal communications with Socorro (March 2015) great care was taken to follow strict protocol of the modified procedures. The steps involved in lipid extraction and separation included first washing all glassware with tap water and soap, and then they were washed three times with deionized water. Lastly, they were placed in a Barnstead Thermolyne ${ }^{\circledR}$ muffle furnace $\mathrm{F} 62700$ for $2 \mathrm{~h}$ at $560^{\circ} \mathrm{C}$ to ensure that all organic matter was removed.

For the analysis, approximately one cubic centimeter of sample was oven dried overnight at $50^{\circ} \mathrm{C}$, then grounded with a Bell-Art micromill to powder and homogenized later with a mortar and pestle. Five grams of homogenized powdered sample was used in a 12 dram vial that was sonicated twice for $30 \mathrm{~min}$ after including a $10 \mathrm{ml}$ mixture of (1:9) methanol $(\mathrm{MeOH}) /$ dichloromethane $(\mathrm{DCM})$. After the supernatant was removed it was allowed to rest in a 4 dram vial with activated copper that was used to remove undesired elemental sulfur. Continued step by step protocol as per Socorro et al., (2017) ensured that 
the fraction containing the hydrocarbons (n-alkanes) was made available for GC/MS analysis At FIU's Chemistry Department Laboratory by a GC (Agilent 6890) employing method 1506GE02.M. An Agilent 5973 single-quadrupole mass spectrometer was operated in positive mode for detection in a scan range from $m / z$, 42 to $m / z 500$.

\section{Redox Sensitive Trace Elements}

Laser Ablation-Inductively Coupled Plasma Mass Spectrometry (LA-ICP-MS) was used to determine concentrations of major and trace elements. ICP-MS analyses were performed at the Florida International University Forensic Center using an ELAN DRC II quadrupole (Perkin Elmer LAS, Shelton CT USA), in standard mode.

Best ablation results, previously evaluated as the best precision and accuracy for reference standards were obtained using a depth profile ablation mode with a $200 \mu \mathrm{m}$ spot size and $10 \mathrm{~Hz}$ with a $266 \mathrm{~nm} \mathrm{Nd-YAG} \mathrm{laser} \mathrm{(LSX} \mathrm{500,} \mathrm{CETAC,} \mathrm{USA)} \mathrm{(Sanchez-}$ Hernandez and Maurrasse, 2014). As reported by these authors, for control samples, two sand blanks of previously known makeup were prepared using the same methodology and conditions as for the 31 samples. Blanks and standards were included at the beginning and end of the sample queue. Glitter software was used for data processing.

Thirty-one (31) samples were analyzed for major and redox sensitive trace elements (RSTEs) using the methodology of Arroyo et al. (2009), and the procedures described in Sanchez-Hernandez and Maurrasse (2014). The samples analyzed were selected from areas of the beds with no visible evidence of weathering, and processed as described for TC preparation for this study. The present study used powdered samples weighted $1.0 \mathrm{~g}$, included with a scandium solution $\left(1000 \mathrm{ppm}\right.$ in $\left.3 \% \mathrm{HNO}_{3}\right)$ as an internal standard. They 
were dried overnight at $80^{\circ} \mathrm{C}$, homogenized with a ball-mill for $15 \mathrm{~min}$, and a manual press was used to convert the samples into pellets.

The study reports the concentrations of trace elements $\mathrm{Ni}, \mathrm{V}, \mathrm{Cr}, \mathrm{Cu}, \mathrm{Mo}, \mathrm{U}, \mathrm{Th}$, and $\mathrm{Co}$, major elements such as $\mathrm{Al}, \mathrm{Si}$ and $\mathrm{Ti}$, and biolimiting elements $\mathrm{P}$, and $\mathrm{Fe}$. Concentrations of these major, biolimiting and trace elements assist in the estimation of nutrient availability, intensity of terrestrial fluxes, and the extent of authigenic enrichment as a proxy for redox conditions (Wignall and Myers, 1988; Calvert and Pedersen, 1993; Morford and Emerson, 1999; Algeo and Maynard, 2004; Rimmer, 2004; Tribovillard et al., 2005). Relative temporal changes are compared to a background level taken as the average of all values in the studied section following the methodology of Stein et al., (2011). The terminology used to indicate relative oxygen-deficient conditions is after Tyson and Pearson (1991) as shown in the Table 1 below:

\begin{tabular}{|c|c|c|c|}
\hline $\begin{array}{l}\text { Oxygen } \\
\mathrm{ml} / \mathrm{I}\end{array}$ & $\begin{array}{l}\text { Oxygenation regime } \\
\text { Environments } \\
\text { Facies }\end{array}$ & Biofacies & $\begin{array}{l}\text { Physiological } \\
\text { regime }\end{array}$ \\
\hline $\begin{array}{l}8.0-2.0 \\
2.0-0.2 \\
2.0-1.0 \\
1.0-0.5 \\
0.5-0.2 \\
0.2-0.0\end{array}$ & $\begin{array}{l}\text { Oxic } \\
\text { Dyxoxic } \\
\text { moderate } \\
\text { severe } \\
\text { extreme } \\
\text { Suboxic }\end{array}$ & $\begin{array}{l}\text { Aerobic } \\
\text { Dysaerobic } \\
\text { Quasi-anaerobic }\end{array}$ & $\begin{array}{l}\text { Normoxic } \\
\text { Hypoxic }\end{array}$ \\
\hline $0.0\left(\mathrm{H}_{2} \mathrm{~S}\right)$ & Anoxic & Anaerobic & Anoxic \\
\hline
\end{tabular}

Table 1. Recommended terminology for low oxygen regimes and the resulting biofacies in marine environments taken from Tyson and Pearson, 1991.

\section{Stable Isotopes of $\delta^{13} C_{\text {org }}$ and $\delta^{15} N_{\text {org }}$}

Carbon and nitrogen isotope analyses on the organic fraction of 67 samples were conducted at the Rosenstiel School of Marine and Atmospheric Science (RSMAS), University of Miami laboratory, on a Finnigan-MAT 251 IRMS. The large radius 
instrument is equipped with microsample inlet, 5 fixed collectors, and an automated sample inlet and multi-port with a Fairbanks automatic carbonate device with an upgraded Apple IIE computer system.

The analytical technique uses $0.1-1.0 \mathrm{mg}$ samples of powdered dry rock. The homogenized rock samples required initial dissolution of the inorganic carbon $\left(\mathrm{CaCO}_{3}\right)$ in a $1 \mathrm{M} \mathrm{HCl}$ solution. Isotopic data are corrected using the procedures of Craig (1957) modified for a triple collector mass spectrometer. Data are quoted relative to Vienna Pee Dee Belemnite (VPDB) according to the conventional notation. The analytical error is approximately $0.1 \%$.

Carbon and nitrogen are essential elements for marine primary production (Marchitto, 2007), and during photosynthesis phytoplankton preferentially incorporates the lighter isotopes $\mathrm{C}^{12}$ and $\mathrm{N}^{14}$ by means of kinetic fractionation. Thus, increased productivity leads to $\delta^{13} \mathrm{C}$ and $\delta^{15} \mathrm{~N}$ enrichments of their original pools (either regional or local depending on whether or not the basin is restricted or open). Hence, higher values of these isotopes provide useful insight into major biogeochemical processes in the paleoenvironments of the sedimentary basin that can be correlated on a regional scale (Hou et al., 2013).

Differential fractionation between diverse photosynthesizers thus leave $\delta^{13} \mathrm{C}$ records that yield valuable understanding of temporal changes in paleoenvironmental conditions (e.g. Godet et al., 2006), the origin of organic matter (OM), the degree of primary productivity, and extent of organic carbon maturity. Because nitrogen is one of the limiting nutrients in the open ocean, $\delta^{15} \mathrm{~N}$ records are used in determining the degree of 
nitrate $\left(\mathrm{NO}_{3}\right)$ utilization, which is employed as a paleoproductivity indicator (Altabet and Francois, 1994; Marchitto, 2007).

In the present study, the chemostratigraphic record of stable carbon isotopes aids in establishing an approximate chronological position for my section by correlating with other Tethyan sections where the chemostratigraphic data is generally accepted (e.g., Godet et al., 2006; Menegatti et al., 1998). 


\section{RESULTS}

\section{Petrographic Analysis}

Thin section study of sixty-seven (67) samples of the 30-m section (Fig. 5) shows facies changes (Pl. 1) as follows: in the lower $4.16 \mathrm{~m}$ the sequence of organic-rich $(<6.66 \%$ TOC) limestones reveals millimeter-scale laminated micrite with low bioturbation index (0-3) (Taylor and Goldring, 1993) and less than 20\% allochems (Folk, 1962) that consist of minute, skeletal fragments from various organisms (Pl. 2. A, B, C, D, E). They consist of echinoderms, sponge spicules, ostracods, small bivalves, textularids $(\sim 200 \mu \mathrm{m})$ and miliolids benthic foraminifers $(\sim 100 \mu \mathrm{m})$, ammonite fragments, radiolarian $(\sim 100 \mu \mathrm{m})$, gastropods $(\sim 800 \mu \mathrm{m})$ and planktic foraminifers $(\sim 100 \mu \mathrm{m})(\mathrm{Pl} .3)$

The lower part of the section includes a black marlstone bed $(\sim 1 \mathrm{~m}$ thick) with low bioturbation index (1), and allochems include planktic foraminifers of the G.blowi Zone (Figs. 5.B, 7) (P1. 3. A, Pl. 4. F). Superjacent beds include allochems types and abundance that coarsen gradually up to $7.02 \mathrm{~m}$ of the section. From the $11.18 \mathrm{~m}$ level upward facies change into a grayish black (N2) biomicritic limestone where calcified sponge spicules (P1.

5. F, P1. 6. B, C) gradually become an important component of the bioclasts. This upper part of the studied section also includes radiolarian, small benthic foraminifers, planktic foraminifers, and echinoderm fragments (P1. 3. B, Pl. 7. A, B, P1. 8).

Serpulid clusters $(\sim 500 \mu \mathrm{m}-1 \mathrm{~mm})(\mathrm{Pl} .8 . \mathrm{C})$ are found intermittently within that interval at levels corresponding to the following samples: CC-15-43 (15.40 m); CC-15-46 (16.96 m); CC-15-50 (18.68 m); CC-15-59 (23.69 m); CC-15-63 (27.08 m); CC-15-65 $(27.99 \mathrm{~m})$. 
Larger fragments of carbonized plant remains $(\sim 100 \mu \mathrm{m}-1 \mathrm{~mm})(\mathrm{Pl} .1$. D, P1. 6. A, P1. 9. A, B, D) occur from the $16.45 \mathrm{~m}$ level where a zone of remarkable dispersive silicification also develops (Fig. 6). The carbonized plant materials persist among the biogenic constituents together with calcified sponge spicules throughout the upper 13.54 $\mathrm{m}$ of the studied section (P1. 5. F, P1. 6. B, C).

Starting at the $19.44 \mathrm{~m}$ level the uppermost part of the studied outcrop consists of a dark gray (N7) biomicritic limestone, moderately bioturbated (index 2-3), showing gradual upward coarsening (Pl. 1). Allochems include radiolarian, planktic foraminifers, sponge spicules, ostracods $(\sim 100 \mu \mathrm{m})$, serpulids, and benthic foraminifers of the miliolid and textularid groups, and nondescript skeletal fragments (P1. 6, Pl. 7, P1. 8. A, B, C, D, E. Pl. 10. F).

\section{SEM and EDS Analyses}

SEM imaging and smear slides (8) revealed predominance of mainly disaggregated nannoconid fragments and calcareous nannofossils as the main micro-carb (Fig. 8). Qualitative EDS analyses of four (4) samples of the Prada Quarry section CC-15-02, CC15-05, CC-15-12, and CC-15-18, indicate $\mathrm{CaCO}_{3}$ as predominant in the rock matrix with little contribution of siliciclastic material as shown in the elemental diagrams (Fig. 9). Photomicrographs of the areas where EDS was performed show fine micritic texture and isotropic distribution of grains (Fig. 9). SEM secondary imaging revealed the presence of framboidal pyrite in sample CC-15-18, level $2.24 \mathrm{~m}(\mathrm{Pl}$. 9. F) and abundant quartz crystals in sample CC-15-42, level $14.60 \mathrm{~m}$ (Pl. 9. C). SEM imaging of samples CC-15-58, level 23.29 $\mathrm{m}$ and CC-15-63, level $27.08 \mathrm{~m}$, illustrates higher plant material in the uppermost 13 m of the Prada Quarry section (P1. 9. A, B, D). 


\section{Total Carbon/Carbonate - TC, TOC, TIC}

Total carbon (TC) content averages $92.48 \%$ throughout the whole sequence as seen in Appendix I, except in the interval between $1.75 \mathrm{~m}$ and $4.16 \mathrm{~m}$ in the black marlstone layer where it drops to $60.45 \%$ at $2.24 \mathrm{~m}$. This value is in sharp contrast to the infrajacent level with $92.50 \%$ and the succeeding level with $94.01 \%$. Likewise, total organic carbon (TOC) averages around $1.70 \mathrm{wt} \%$ throughout the whole sequence showing minor fluctuations, except at $2.24 \mathrm{~m}$ where it reaches a high of $6.66 \mathrm{wt} \%$ in the black marlstone layer (Fig. 10) compared to an average of $2.13 \mathrm{wt} \%$ below this level and $1.43 \mathrm{wt} \%$ above it. TIC fluctuates between $99.13 \mathrm{wt} \%$ and $86.12 \mathrm{wt} \%$ with an average of $90.79 \mathrm{wt} \%$, and it negatively correlates with TOC $\left(\mathrm{R}^{2} \sim-.83\right)$, generally following an inverse fluctuating correlation with TOC. As shown in Figure 10 and Appendix I, the highest TOC values occur within the lower $4.16 \mathrm{~m}$ of the section that includes the black marlstone layer.

Noticeably there are two other smaller scale increases in the TOC, one reaching a high of $2.18 \mathrm{wt} \%$ at $17.98 \mathrm{~m}$ (sample CC-15-48) between the $16.96 \mathrm{~m}$ and $18.68 \mathrm{~m}$ interval where the average TOC is $1.24 \mathrm{wt} \%$ (Fig. 10). The second fluctuation occurs at $27.08 \mathrm{~m}$ with maximum value of $2.55 \mathrm{wt} \%$ coincident also with an increase in plant fragments. This TOC peak lies within the interval $26.42 \mathrm{~m}$ and $27.99 \mathrm{~m}$ where the average TOC is 1.39 $w t \%$ (Fig. 10). These two TOC peaks are inversely correlated with TIC with $\mathrm{R}^{2} \sim-.47$ in the first, and $\mathrm{R}^{2} \sim-.89$ in the second occurrence, respectively.

\section{Biomarkers Analysis}

Lipid biomarkers ( $n$-alkanes) are used to determine provenance of organic matter (Giger et al., 1980; Meyers, 1997; Dumitrescu and Brassell, 2005; Peters et al., 2005, 
Sanchez-Hernandez and Maurrasse, 2016). The analyses of 28 samples show a predominance of short chain $n$-alkanes $(<\mathrm{nC} 20)$ in the lower part of the sequence (Fig. 11). The $n$-alkane chain lengths increase to $\sim \mathrm{nC} 26$ and higher above the black marlstone layer.

At the 16.45 m-level contribution of $n \mathrm{C}_{20}-n \mathrm{C}_{30}$ coincides with the presence of carbonized plant remains which persist throughout the upper part of the studied Prada Quarry section (Fig. 11) (Pl. 1. D, Pl. 6. A, Pl. 9. A, B, D).

Pristane/Phytane ratios show low values between 0.29 and 1.28 , which are comparable to previously recorded results in the Organyà Basin (Sanchez-Hernandez \& Maurrasse 2014; Socorro et al., 2017) (Fig. 2) (Appx. II).

\section{Redox Sensitive Trace Elements}

Concentrations of major, and trace elements are reported in parts per million (ppm) (Figs. 12-13) (Appx. III). A spike in values obtained for major, biolimiting, and RSTEs (Al, Si, Ti), (P, Fe), and (V, Cr, Cu, Mo, Th) occurs at $2.24 \mathrm{~m}$ in the black marlstone layer, within the interval between $1.75 \mathrm{~m}$ and $4.16 \mathrm{~m}$ (Figs. 12-13). That interval also shows prominent spikes for lithophile elements $\mathrm{Al}$ (maximum $57512 \mathrm{ppm}$ ) and $\mathrm{Ti}$ (maximum $2561 \mathrm{ppm})$ which positively correlate $\left(\mathrm{R}^{2} \sim .99\right)$, and $\mathrm{Si}$ with a value of $126366 \mathrm{ppm}$ or $\sim 126.3 \mathrm{ppt}$, (Fig. 12). However, silicon has its highest value at the $16.45 \mathrm{~m}$ level of the succession with 156805 ppm (Fig. 12) that coincides with the stratigraphic level of silicified lenses observed at the outcrop scale (Fig. 6).

Maximum elemental values versus their background equivalent in the section yielded the following relationships: 12 times the background values for $\mathrm{Al}$ and $\mathrm{Ti}$, and 6 times the background values for $\mathrm{Si}$. Iron also shows a strong correlation with $\mathrm{Al}, \mathrm{Ti}$, and Si which is $\mathrm{R}^{2} \sim 0.99, \mathrm{R}^{2} \sim 1$, and $\mathrm{R}^{2} \sim 0.64$ respectively. At $2.24 \mathrm{~m}$ Fe also peaks with a 
value of $26652 \mathrm{ppm}$, which is 11 times its background values. Although phosphorus does not correlate as well with Fe and the lithophile elements at the exact data point of $2.24 \mathrm{~m}$, its second highest recorded value in the section is $126366 \mathrm{ppm}$ at $2.65 \mathrm{~m}$ on top of the black marlstone layer (Fig. 12). The following elements: $\mathrm{V}, \mathrm{Cr}, \mathrm{Ni}, \mathrm{Cu}$, and $\mathrm{Th}$ also reach their highest values at the $2.24 \mathrm{~m}$ level (Fig. 13) (Appx. III), where they show good correlation with the lithophile elements and Fe. Similarly, at the same level V maximum value is 87.1 ppm being 5 times more than the background value, $\mathrm{Ni}$ reaches $61.2, \mathrm{Cr} 71.5, \mathrm{Cu} 21.4$, and Th $4.6 \mathrm{ppm}$ respectively. Uranium highest values occur at two intervals: $4.5 \mathrm{ppm}$ at the $17.98 \mathrm{~m} \mathrm{level}$, and a maximum of $5.25 \mathrm{ppm}$ at the $27.08 \mathrm{~m}$ level (Fig. 13). These peak values also correlate with all other trace elements as shown in Figures 12 and 13.

Lower $\mathrm{U}$ values within the first $4.88 \mathrm{~m}$ of the section show poor correlation $\left(\mathrm{R}^{2} \sim\right.$ 0.34) with bulk $\mathrm{P}$, which can be used as a proxy for authigenic phosphate (Hoffman et al., 1998; Algeo and Maynard, 2004), whilst in the last $15.64 \mathrm{~m}$ this correlation improves by approximately $64 \%$ between the two elements with a value of $\mathrm{R}^{2} \sim 0.53$ (Fig. 14).

\section{Stable Isotopes of $\delta^{13} C_{\text {org }}$ and $\delta^{15} N_{\text {org }}$}

Organic $\delta^{13} \mathrm{C}$ (Fig. 10) fluctuates throughout the $30 \mathrm{~m}$-section studied, with an overall positive trend up section. The lowest value of $-26.24 \%$ is recorded at $0.66 \mathrm{~m}$ to a high of -23.78\%, ( 2.46\% maximum increase) at $18.05 \mathrm{~m}$. As shown in Figure 10, higher amplitude fluctuations occur towards the top of the section. There is a $1.44 \% 0 \delta^{13} \mathrm{C}_{\mathrm{org}}$ shift between the $14.19 \mathrm{~m}$ and $19.29 \mathrm{~m}$ interval peaking at $18.05 \mathrm{~m}$ (Fig. 10). Another $\delta^{13} \mathrm{C}_{\text {org }}$ small positive inflection from $-24.40 \%$ to $-23.91(0.50 \%)$ occurs at the interval between $25.53 \mathrm{~m}$ and $27.99 \mathrm{~m}$ peaking at $27.08 \mathrm{~m}$. 
The $\delta^{15} \mathrm{~N}_{\text {org }}$ isotopic curve displays the same general positive trend toward the top of the section as does the carbon isotope curve. Its values range from $1.82 \%$ to $5.95 \%$ averaging $4.50 \%$. The lowest $3 \mathrm{~m}$ of the section show a range of low amplitude highfrequency fluctuations non-concurrent with the high frequency oscillations of the $\delta^{13} \mathrm{C}$ $\left(<1 \%\right.$ ) and $\delta^{15} \mathrm{~N}_{\mathrm{org}}(<1.50 \%$ ) within the same interval (Fig. 10). From this interval, upward $\delta^{15} \mathrm{~N}_{\text {org }}$ values approximately correlate positively (Fig. 10) with the $\delta^{13} \mathrm{C}_{\text {org }}$ profile. A sharp $3.72 \%{ }^{15} \mathrm{~N}_{\text {org }}$ positive excursion develops from the $16.96 \mathrm{~m}$ level to the $18.68 \mathrm{~m}$ peaking at $17.98 \mathrm{~m}$ (Fig. 10) and $18.05 \mathrm{~m}$ concurrent with a positive shift of $1.44 \%{ }^{13} \mathrm{C}_{\text {org. }}$. The highest $\delta^{15} \mathrm{~N}_{\text {org }}$ value of $5.95 \%$ is found at the $27.08 \mathrm{~m}$ level, which also defines a sharp $2.57 \%$ positive excursion correlative with a $\delta^{13} \mathrm{C}_{\text {org }}$ shift to $-23.91 \%$ (Fig. 10 ). 


\section{DISCUSSION}

\section{Relative Chronology}

The identification of Globigerinelloides blowi (Bolli, 1959), Hedbergella sigali (Moullade 1966) (Fig. 7) (Pl. 3. A, Pl. 4. F, Pl. 8. B), characteristic of the G. blowi Biozone in the studied section (Fig. 5) implies a biochronology between the latest Barremian and the early Aptian. However, because of the long range of the nominate taxon, and problems associated with the lack of the index species found elsewhere in sediments of the Organyà Basin (Sanchez-Hernandez et al., 2014), perhaps, a more definite approach to determine the relative geochronological position of the studied section can be done with the use of the $\delta^{13} \mathrm{C}$ data. In fact, as discussed in Sanchez-Hernandez and Maurrasse (2016) C-isotope signatures show a consistency and dependability despite modulation related to local or regional factors. Hence, the C-isotope patterns allow their use for chronologic correlation (e.g. Kuhnt et al., 2011; Li et al., 2016). Based on similar characteristic, the C-isotope curve

of the studied section is here compared with sites elsewhere such as the shallow-water Cresmina section from the North Atlantic (Burla et al., 2008), and the pelagic Gorgo a Cerbara section (Stein et al., 2011) (Fig. 14).

Three $\delta^{13} \mathrm{C}_{\text {org }}$ positive peaks can be correlated with peaks from these two sections in the Tethys and North Atlantic. The Cresmina section is chosen for this $\delta^{13} \mathrm{C}$ correlation as its carbon isotope curve exhibits a similar trend evident in the studied Prada Quarry section. Also, Burla et al., (2008) successfully correlated the coastal $\delta^{13} \mathrm{C}$ records of the Cresmina section to other Tethyan reference sections namely Cismon (Menegatti et al., 
1998). Based on the correlation, they concluded that the upper part of the Cresmina section was deposited close in time and before the Early Aptian Oceanic Anoxic Event (OAE1A).

The second site is the pelagic Gorgo a Cerbara section in central Italy (Stein et al., 2011), in the Umbria Marche Basin, which is regarded as the OAE1 a type locality (Pancost et al., 2004) and is proposed as a possible GSSP (Global Stratotype Section and Point) for the Barremian-Aptian boundary (Erba, 1996). This section also displays a $\delta^{13} \mathrm{C}$ trend that has been correlated (Stein et al., 2011) with the same Cismon reference section (Menegatti et al., 1998).

Similarities in the patterns of the C-isotope curve of the studied Prada quarry section with these sections (Fig. 14) in the North Atlantic and Tethyan realm further permits to infer a relative chronological position between the late Barremian and the early Aptian. Segment boundaries are established by inflection patterns and/or changing gradients of the carbon isotope curve and have been determined in those parts of the curves that show distinct trends allowing approximate correlation (Fig. 14).

The correlation strategy allowed for the identification of at least three positive peaks shared by the three sections. The Prada Quarry correlative inflections are found at the $18.05 \mathrm{~m}, 21.49 \mathrm{~m}$, and $27.08 \mathrm{~m}$ levels with $-23.78 \%$, $-24.50 \%$, and $-24.91 \% 0 \delta^{13} \mathrm{C}_{\mathrm{org}}$ values respectively. The Gorgo a Cerbara counterparts relative stratigraphic positions are found at the $17.98 \mathrm{~m}, 19.62 \mathrm{~m}$, and $21.61 \mathrm{~m}$ levels with isotopic values of $-25.64 \%$, $-24.9 \%$, and $-24.8 \%$ respectively.

The isotopic data within the stratigraphic intervals of the Prada Quarry section that include these positive inflections show moderate correlation $\left(\mathrm{R}^{2} \sim 0.5\right)$ with Gorgo a Cerbara's values for the same proposed levels. Although there is a slight positive 
divergence of $\sim 1 \%$ o $\delta^{13} \mathrm{C}_{\text {org }}$ from mean values of the Prada Quarry section (-24.61\%o) as compared to $(-25.88 \%)$ of the Gorgo a Cerbara's subsection, nonetheless both isotope curves display a similar pattern. Such differences may be explained by contribution of the organic matter from different origins (e.g. Sanchez-Hernandez and Maurrasse, 2016; Socorro and Maurrasse, 2017; and others herein).

The length of the stratigraphic interval used for carbon isotope chronological correlation in the Prada Quarry is $9.43 \mathrm{~m}$ as compared to an equivalent $3.97 \mathrm{~m}$ in the Gorgo a Cerbara section. The difference stems from a sharp decrease in accumulation rate to 0.28 cm.kyr ${ }^{-1}$ in the upper part of the Maiolica limestones at the onset of the Fucoidi marls (Fig. 14) in the latter area (Speranza et al., 2005). In contrast, recent studies of the Organyà Basin at the El Pui section propose minimum accumulation rates of 5 to $7.5 \mathrm{~cm} . \mathrm{ky}^{-1}$ (SanchezHernandez and Maurrasse, 2014).

Based on these proposed rates, comparison of the correlated intervals for the Cisotope curves chronology would imply that the $9.43 \mathrm{~m}$ Prada Quarry subsection represents $\sim 125 \mathrm{kyr}$, while the Gorgo a Cerbara section $\sim 140 \mathrm{kyr}$. These values closely approximate coeval time of deposition compatible with the proposed chronological correlation based on $\delta^{13} \mathrm{C}_{\text {org }}$ values for these sections.

\section{Paleoenvironments / Lithofacies}

Microfacies showing low to moderate bioturbation (0-3 index) in biomicritic limestones with a mix of planktic foraminifers, abundant miliolids, textularids, serpulids, radiolarian and ammonite fragments, bivalves, and gastropods (Pl. 2, Pl. 5. B, C, D, Pl. 8 , Pl. 9. E, Pl. 10. F) are interpreted as deep-platform facies in open marine setting below 
storm-weather wave base. The presence of radiolarians (P1. 5. B, D, P1. 9. E) suggests some degree of upwelling developed in the basin.

Facies change at the $11.18 \mathrm{~m}$ level (P1. 1. C) where biomicritic limestones include

calcified sponge spicules which become gradually more abundant together with small benthic foraminifers (P1. 3. B, P1. 7. A, P1. 10. B), echinoderm fragments, and serpulids may also represent deep-platform facies under apparent low energy subsurface currents that sustained abundance of the filter feeders, and possibly upwelling as radiolarians are also found at this level.

The $16.45 \mathrm{~m}$ interval (Pl. 1. D) is characterized by increased carbonized plant materials together with calcified sponge spicules throughout the rest of the sequence. The abundance of the sponge spicules provides an explanation for the provenance of remobilized silica in the horizon with silicified lenses (Fig. 6), which is also confirmed by major element data analysis, and low TIC (51.33 wt\%) of sample CC-15-45 (Fig. 10, 12).

The uppermost part of the studied section starting at the $19.44 \mathrm{~m}$ level with coarsening bioclasts (P1. 1. E, F) and moderate bioturbation index (2-3), biomicritic limestone is interpreted also as a deep-platform environment of deposition with a faunal association including planktic foraminifers, small benthic foraminifers (textularids, miliolids), serpulids, radiolarians, and ammonite fragments (Pl. 6. E, F, Pl. 7. D, P1. 8. C).

\section{Chemostratigraphy / Elemental Content}

Redox sensitive trace elements (RSTEs) in general are prone to be more soluble under oxidizing environments (Algeo and Maynard, 2004; Tribovillard et al. 2004, 2006; Stein et al., 2011). The mechanism of elemental uptake into the sediments in reducing conditions of oxygen deficiency between 2.0 to $0.2 \mathrm{ml} / 1 \mathrm{O}_{2}$ and lower (see Table 1) is 
partial to the formation of organo-metallic ligands in humic acids, by surface adsorption (Tribovillard et al., 2004). Enrichment spikes of RSTEs (Mo, Cr, Cu, V, Th, U) shown in Figure 13 indicate recurrence of oxygen-deficient conditions, which is more pronounced between $1.75 \mathrm{~m}$ and $4.16 \mathrm{~m}$ (Fig. 12-13) (Appx. III) at the level of the black marlstone layer as compared to superjacent levels. RSTEs enrichment combined with the absence of benthic foraminifers at that level suggest an episode of stronger oxygen-deficient conditions surmised to be suboxic corroborated by the presence of pyrite framboids (Pl. 9 . F). Furthermore, TOC content $(<6.66 \mathrm{wt} \%)$, and higher Ni/Co value of $\sim 21 / 2$ times its background compared to the rest of the sequence lend credence to this assumption.

\section{Biomarkers}

The predominance of short chain $n$-alkanes $(<\mathrm{nC} 20)$ in the studied section (Fig. 11) (Appx. IV) implies in situ origin of the OM from phytoplankton, and the increase of $n \mathrm{C}_{20}$ $n \mathrm{C}_{26}$ before and after the onset of the black marlstone layer with diagnostic dysoxic/anoxic characteristics suggests a contribution from aquatic macrophytes (Ficken et al., 2000). Further contribution of $n \mathrm{C}_{20}-n \mathrm{C}_{30}$ from the $16.45 \mathrm{~m}$ level coincident with increased carbonized plant remains (Fig. 11) (Pl. 6. A, Pl. 9. A, B, D) indicates an increased origin of higher plant organic matter in the basin at that time.

The Pristane/Phytane ratios (Pr/Phy) (Appx. II) vary between 0.29 and 1.28, thus below the threshold level $(>2.5)$, and since the $n$-alkanes are primarily from the basin, these values thus imply that $\mathrm{OM}$ did not reach an overmature state, confirming previous $n$-alkane results in the Organyà Basin (Sanchez-Hernandez \& Maurrasse 2014; Socorro et al., 2017). The Pr/Phy values also bring additional evidence to severe oxygen-deficient conditions of deposition (Didyk et al., 1978), because such environments tend to preserve the $\mathrm{C}_{20}$ 
isoprenoid skeleton yielding low $\mathrm{Pr} / \mathrm{Phy}$ ratios (Appx. II). Oxic conditions, on the other hand, cause greater degradation so that the $\mathrm{C}_{20}$ isoprenoid skeleton is less likely to remain intact in the sediment (Didyk et al., 1978). 


\section{CONCLUSIONS}

The high resolution, multiproxy study of the 30-m section of the Sierra de Prada Quarry provides further detailed lithostratigraphic and geochemical data to improve our knowledge of the paleoecological conditions in the sedimentary sequence of the Organyà Basin exposed in the eastern Sierra de Prada Quarry. The results provide additional data to previous studies (Berástegui et al., 1990; Caus et al., 1990; García-Senz, 2002; Bernaus, et al., 2003; Sanchez-Hernandez and Maurrasse, 2014, 2015, 2016; Socorro et al., 2017.

Index taxa include planktic foraminifera G.blowi, Hedbergella sigali, which combined with the $\delta^{13} \mathrm{C}$ data in comparison with two other sections (Cresmina and Gorgo a Cerbara) suggest a relative chronological level between the late Barremian and the early Aptian. The rocks are organic-rich $(0.67-3.10 \mathrm{wt} \% \mathrm{TOC})$, and a single black marlstone layer ( $1 \mathrm{~m}$ thick) at $2.24 \mathrm{~m}$ which shows low bioturbation index (1), TOC up to $6.66 \mathrm{wt} \%$ coeval with framboidal pyrite, and enrichment spikes of RSTEs indicate a distinct dysoxic/anoxic episode within overall sustained oxygen-deficient conditions.

Biomarker analyses show a predominance of $n$-alkanes $(\leq \mathrm{nC} 20)$ in the lower 4.16 $\mathrm{m}$ of the section which suggest in situ origin of the OM from phytoplankton. The occurrence of $\leq \mathrm{nC} 26$ before and after the black marlstone layer reveals added contribution from aquatic macrophytes coincident with the onset of the anoxic/dysoxic episode. Contribution of $\leq \mathrm{nC} 30$ observed at the $16.45 \mathrm{~m}$ level coincides with higher concentration of carbonized higher plant remains. Pr/Phy ratios below $2(0.29-1.28)$, imply that OM did not reach overmaturity. 
Sediments of the Eastern Prada Quarry section may be interpreted as hemipelagic marine deposits of the outer shelf environment during widespread development and accumulation of organic-rich sediments under greenhouse conditions.

\section{Recommendations for Future Research}

In order to further elucidate the overall paleoenvironmental conditions recorded in sediments of the Organyà Basin in the Eastern Sierra de Prada Quarry, a suite of three different proxies is proposed:

1. - Bulk and clay mineral analyses by means of X-ray diffraction (XRD), to evaluate the mineralogical makeup of the rock matrix, and characterization of the detrital fraction. X-ray diffraction (XRD).

2. - Rock Eval Pyrolysis can be employed to further evaluate the organic matter type, quantity and maturity and, the potential generation of hydrocarbon. The method will provide data on free hydrocarbons contained in the sample and the hydrocarbon- and oxygen-containing compounds $\left(\mathrm{CO}_{2}\right)$ (Tissot and Welte, 1984).

3. - Investigate the hopanoids biomarker group to evaluate the biotic sources of the organic matter, maturity, measures of its depositional environment, and mechanism of preservation (Forster et al., 2004). Hopanes are pentacyclic triterpenoids derived from cell membranes of prokaryotes (phototrophic cyanobacteria and also heterotrophic bacteria) (e.g., Ourisson et al., 1987; Ourisson and Rohmer, 1992).

This biomarker group is distinguished by maturity-sensitive stereoisomers (Seifert and Moldowan, 1980; Forster et al., 2004). Thermal maturity results obtained from hopane's maturity-sensitive isomers could then be correlated and corroborated with $\mathrm{T}_{\max }$ 
results from Rock Eval Pyrolysis to confirm interpretation of the origin of organic matter in the Prada Quarry section. 


\section{LIST OF REFERENCES}

Algeo, T.J., Maynard J. B., 2004. Trace element behavior and redox facies in core shales of Upper Pennsylvanian Kansas-type cyclothems, Chemical Geology 206, 289-318.

Altabet, M. A., and Francois, R., 1994. Sedimentary nitrogen isotopic ratio as a recorder for surface ocean nitrate utilization. Global Biogeochemical Cycles 8, 103-116.

Arroyo, L., Trejos, T., Gardinalli, P.R., Almirall, J.R., 2009. Optimization and validation of a Laser Ablation Inductively Coupled Plasma Mass Spectrometry method for the routine analysis of soils and sediments. Spectrochimica Acta Part B 64, 16-25.

Bachmann, M., Willems, H., 1996. High-frequency cycles in the upper Aptian carbonates of the Organyà basin, NE Spain. Geologische Rundschau 85(3), 586-605.

Bengtsson, L. \& M. Enell, 1986. Chemical analysis. In Berglund, B. E. (ed.), Handbook of Holocene Palaeoecology and Palaeohydrology, 423-451.

Berástegui, X., García-Senz, J.M., Losantos, M., 1990. Tectonosedimentary evolution of the Organyà extensional basin (Central South Pyrenean Unit, Spain) during the Lower Cretaceous. Bulletin de la Société Géologique de France 8, VI, 2, 251-264.

Bernaus, Josep-Maria., 1998. L'Urgonien du bassin d'Organya (NE Espagne) :micropaleontologie, sedimentologie et stratigraphie sequentielle. Stratigraphie. Universite Joseph-Fourier - Grenoble I.

Bernaus, J.M., Arnaud-Vanneau, A., Caus, E., 2002. Stratigraphic distribution of Valanginian Early Aptian shallow-water benthic foraminifera and algae, and depositional sequences of a carbonate platform in a tectonically-controlled basin: the Organyà Basin, Pyrenees, Spain. Cretaceous Research 23, 25-36.

Bernaus, J.M., Arnaud-Vanneau, A., Caus, E., 2003. Carbonate platform sequence stratigraphy in a rapidly subsiding area: the Late Barremian-Early Aptian of the Organyà Basin, Spanish Pyrenees. Sedimentary Geology 159 (3-4), 177-201.

Bolli, H., 1959. Planktonic foraminifera from the Cretaceous of Trinidad, B.W.I. Bulletins of American Paleontology 39, 257-277.

Burla, S., Heimhofer, U., Hochuli, P.A., Weissert, H., Skelton, P., 2008. Changes in sedimentary patterns of coastal and deep-sea successions from the North Atlantic (Portugal) linked to Early Cretaceous environmental change. Palaeogeography, Palaeoclimatology, Palaeoecology 257, 38-57. 
Bralower, T. J., Arthur, M. A., Leckie, R. M., Sliter, W. V., Allard, D. J., Schlanger, S.O., 1994. Timing and paleoceanography of oceanic dysoxia/anoxia in the LateBarremian to Early Aptian (Early Cretaceous). Palaios, 9(4), 335-369.

Calvert, S.E., Pedersen, T.F., 1993. Geochemistry of recent oxic and anoxic marine sediments: implications for the geological record. Marine Geology 113, 67-88.

Caus, E., García-Senz, J. M., Rodés, D., Simó, A. 1990. Stratigraphy of the Lower Cretaceous (Berriasian-Barremian) sediments in the Organyà Basin, Pyrenees, Spain. Cretaceous Research 11, 313-320.

Craig, Harmon, 1957. Isotopic standards for carbon and oxygen and correction factors for mass-spectrometric analysis of carbon dioxide. Geochimica et Cosmochimica Acta. Volume 12, Issues 1-2, Pages 133-149.

Dean, W. E. Jr., 1974. Determination of carbonate and organic matter in calcareous sediments and sedimentary rocks by loss on ignition: Comparison with other methods. J. Sed. Petrol. 44: 242-248.

Dumitrescu, M., Brassell, S.C., 2005. Biogeochemical assessment of sources of organic matter and paleoproductivity during the early Aptian Oceanic Anoxic Event at Shatsky Rise, ODP Leg 198, Organic Geochemistry 36 (7), 1002-1022.

Dunham, R. J., 1962. Classification of carbonate rocks according to depositional textures, in Ham, W, E. (ed.), Classification of carbonate rocks: American Association of Petroleum Geologists Mem. 1, p. 108-121.

Didyk, B.M., Simoneit, B.R.T., Brassell, S.C., Eglington, G., 1978. Organic geochemical indicators of palaeoenvironmental conditions of sedimentation. Nature 272, $216-$ 222.

Erba, E., 1996. The Aptian Stage. Bulletin de l'Institut Royal des Sciences Naturelles de Belgique, Sciences de la Terre (66-Supp.), 31-43.

Erba, E., Channell, J.E.T., Claps, M., Jones, C., Larson, R., Opdyke, B., Premoli Silva, I., Riva, A., Salvini, G., Torricelli, S., 1999. Integrated stratigraphy of the Cismon APTICORE (Southern Alps, Italy): a "reference section" for the Barremian-Aptian interval at low latitudes. Journal of Foraminiferal Research 29, 371-392.

Erba, E., 2004. Calcareous nannofossils and Mesozoic oceanic events. Marine micropaleontology 52, 85-106.

Ficken, K.J., Li, B., Swain, D.L., Eglinton, G., 2000. An $n$-alkane proxy for the sedimentary input of submerged/floating freshwater aquatic macrophytes. Organic Geochemistry 31, 745-749. 
Folk RL (1962) Spectral subdivision of limestone types. In: Ham WE (ed) Classification of carbonate rocks: AAPG Memoir 1:62-84.

Forster, A., Sturt, H., Meyers, P.A., and the Leg 207 Shipboard Scientific Party, 2004. Molecular biogeochemistry of Cretaceous black shales from the Demerara Rise; preliminary shipboard results from Sites 1257 and 1258, ODP Leg 207, In:

Erbacher, J., Mosher, D.C., Malone, M.J., et al. (eds.), Proceedings of the Ocean Drilling Program, Initial Results 207, 1-22.

Gaona-Narvaez, T., Maurrasse, F.J-M.R., Moreno-Bedmar, J. A., 2013a. Stable Carbon Isotope Stratigraphy and Ammonite Biochronology at Madotz (Navarra, N Spain): Implications for the Timing and Duration of Oxygen Depletion during OAE-1a. Cretaceous Research 40,143-157.

Gaona-Narvaez, T., Maurrasse, F.J-M.R., Etayo-Serna, F., 2013b. Geochemistry, paleoenvironments and timing of Aptian organic-rich beds of Paja Formation (Curití, Eastern Cordillera, Colombia). In: Bojar, A.V., Melinte-Dobrinescu, M.C., and Smit, J. (Eds.), Isotopic Studies in Cretaceous Research. Geological Society of London, Special Publications 382, 31-48.

García-Senz, J., 2002. Cuencas extensivas del Cretácico Inferior en los Pirineos Centrales: formación y subsecuente inversión. PhD Thesis, University of Barcelona, Barcelona, $310 \mathrm{pp}$.

Giger, W., Schaffner, C., Wakeham, S. G., 1980. Aliphatic and olefinic hydrocarbons in recent sediments of Greifensee, Switzerland. Geochimica et Cosmochimica Acta 44, 119-129.

Goddard, E.N., Trask, P. D., De Ford, R. K., Rove, O.N., Singewald, J.T., Overbeck, R.M., 1963, Rock-Color Chart. Distributed by the Geological Society of America, New York, N.Y. 16 p.

Godet, A., Bodin, S., Föllmi, K., Vermeulen, J., Gardin, S., Fiet, N., Adatte, T., Berner, Z., Stüben, D., van de Schootbrugge, B., 2006. Evolution of the marine stable carbonisotope record during the Early Cretaceous: a focus on the late Hauterivian and Barremian in the Tethyan realm. Earth and Planetary Sciences Letters 242, $254-271$.

Godet, A., Bodin, S., Adatte, T., Föllmi, K.B., 2008. Platform-induced clay-mineral fractionation along a northern Tethyan basin-platform transect: implications for the interpretation of Early Cretaceous climate change (Late Hauterivian-Early Aptian). Cretaceous Research 29, 830-847.

Golonka, J., 2004. Plate tectonic evolution of the southern margin of Eurasia in the Mesozoic and Cenozoic. Tectonophysics 381, 235-273. 
Hays, J.D. and Pitman, W.C., 1973. Lithospheric plate motion, sea level changes and climatic and ecological consequences. Nature, 246, 18-22.

Heiri, Oliver., Lotter, Andre F., Lemcke, Gerry., 1999. Loss on ignition as a method for estimating organic and carbonate content in sediments: reproducibility and comparability of results. Journal of Paleolimnology 25, 101-110.

Hou, W., Gu, B., Zhang, H., Gu, J., Han, B., 2013. The relationship between carbon and nitrogen stable isotopes of zooplankton and select environmental variables in low-latitude reservoirs. Limnology, 14, 97-104.

Hoffman, D.L., Algeo, T.J., Maynard, J.B., Joachimski, M.M., Hower, J.C., Jaminski, J., 1998. Regional and stratigraphic variation in bottomwater anoxia in offshore core shales of Upper Pennsylvanian cyclothems from the Eastern Midcontinent Shelf (Kansas), USA. In: Schieber, J., Zimmerle, W., Sethi, P.S.(Eds.), Shales and Mudstones, vol. 1, 243-269.

Jenkyns, H. C., 1980. Cretaceous anoxic events: from continents to oceans. Journal of the Geological Society, London 137, 171-188.

Kerr, A.C., 1998, Oceanic plateau formation: a cause of mass extinction and black shale deposition around the Cenomanian-Turonian boundary? Journal of the Geological Society, London, 155, 619-626.

Kuhnt, W., Holbourn, A., Moullade, M., 2011. Transient global cooling at the onset of early Aptian oceanic anoxic event (OAE) 1a. Geology 39(4), 323-326.

Larson, R. L., 1991a. Geological consequences of superplumes, Geology 19, 963-966.

Larson, R.L., Erba, E., 1999. Onset of the mid-Cretaceous greenhouse in the Barremian Aptian: igneous events and the biological, sedimentary, and geochemical responses. Paleoceanography 14, 663-678.

Li, Y.X., Bralower, T.J., Montanez, I.P., Osleger, D.A., Arthur, M.A., Bice, D.M., Herbert, T.D., Erba, E., Premoli Silva, I., 2008. Toward an orbital chronology for the early Aptian Oceanic Anoxic Event (OAE1a, similar to $120 \mathrm{Ma}$ ). Earth and Planetary Science Letters 271, 88-100.

Li, J., Hu, X., Zhao, K., Cai, Y., Sun, T., 2016. Paleoceanographic evolution and chronostratigraphy of the Aptian Oceanic Anoxic Event 1a (OAE1a) to oceanic red bed 1 (ORB1) in the Gorgo a Cerbara section (central Italy). Cretaceous Research 66, 115-128.

Marchitto, T.M., 2007. Nutrient Proxies. Paleoceanography, Physical and Chemical Proxies/nutrient proxies. Encyclopedia of Quaternary Science (Second Edition), 2013, 899-906. 
Martínez, R., 1982. Ammonoideos cretácicos del Prepirineo de la provincia de Lleida. $\mathrm{PhD}$ thesis, publicaciones de la Universitat Autónoma de Barcelona, 17, pp. 197.

Menegatti, A. P., Weissert, H., Brown, R. S., Tyson, R. V., Farrimond, P., Strasser, A. \& Caron, M., 1998. High resolution $\square$ 13C stratigraphy through the Early Aptian "Livello Selli" of the Alpine Tethys. Paleoceanography 13 (5), 530-545.

Meyers, P.A., 1997. Organic geochemical proxies of paleoceanographic, paleolimnologic, and paleoclimatic processes, Organic Geochemistry 27, 213-250.

Mey, P.H.W. Nagtegaal, P.J.C, Roberti, K.J., Hartevelt, J.J.A., 1968. Lithostratigraphic Subdivision of Post-Hercynian Deposits in the South-Central Pyrenees, Spain. Leidse Geologische Mededelingen, 41, 221-228.

Morford, J.L., Emerson, S., 1999. The geochemistry of redox sensitive trace metals in sediments. Geochimica et Cosmochimica Acta 63, 1735-1750.

Moullade, M., 1966. Etude stratigraphique et micropaleontologique du Crétacé inférieur de la "fosse vocontienne". Documents des Laboratoires de Géologie de la Faculté des Sciences de Lyon, 15: 1-369.

Muñoz, J.A., 1991. Evolution of a continental collision belt: ECORS-Pyrenees crustal balanced cross-section, In Thrust Tectonics Ed. K.R. McClay. Chapman and Hall, New York, pp.235-247.

Muñoz, J.A., Pardo, G., Villena, J., 1992. Evolucion paleogeografica de los conglomerados miocenos adosados al borde norte de la Sierra de Cameros (La Rioja). Acta Geologica Hispanica 27, 3-14.

Mutterlose, J., Böckel, B. 1998. The Barremian-Aptian interval in NW Germany: a review. Cretaceous Research 19(5), 539-568.

Mutterlose, J., Pauly, S., Steuber, T., 2009. Temperature controlled deposition of early Cretaceous (Barremian-early Aptian) black shales in an epicontinental sea.

Palaeogeography, Palaeoclimatology, Palaeoecology 273(3), 330-345.

Ourisson, G., Rohmer, M., and Poralla, K., 1987. Prokaryotic hopanoids and other polyterpenoid sterol surrogates. Annual Review of Microbiology 41, 301-333.

Ourisson, G., and Rohmer, M., 1992. Hopanoids. 2. Biohopanoids: a novel class of bacterial lipids. Accounts of Chemical Research 25, 403-408.

Pauly, S., Mutterlose, J., Wray, D.S., 2013. Palaeoceanography of Lower Cretaceous (Barremian-Lower Aptian) black shales from northwest Germany evidenced by calcareous nannofossils and geochemistry. Cretaceous Research 42, 28-43. 
Pancost, R.D., Crawford, N.,Magness, S., Turner, A., Jenkyns, H.C.,Maxwell, J.R., 2004. Further evidence for the development of photic-zone euxinic conditions during Mesozoic oceanic anoxic events. Journal of the Geological Society, London 161, 353-364.

Peybernès, B., 1976. Le Jurassique et le Crétacé infèrieur des Pyrénées francoespagnoles. Thèse de doctorat, Laboratoire de Géologie, Université Paul Sabatier, Toulouse, $459 \mathrm{pp}$.

Peybernès, B. and Souquet, P., 1973. Biostratigraphie des marnes noires de 1 'AptienAlbien de la zone sud-pyrénéenne. Comptes Rendus de l'Académie des Sciences Paris 276 (2 Mai 1976), Séries D, 2501-2504.

Peters, K.E., Walters, C.C., Moldowan, J.M., 2005. The biomarker guide: II, Biomarkers and isotopes in petroleum systems and Earth history, Cambridge, UK, Cambridge University Press, pp. 475-1155.

Rimmer, S.M., 2004. Geochemical paleoredox indicators in Devonian-Mississippian black shales, central Appalachian Basin (U.S.A.). Chemical Geology 206, 373391.

Rosell, J., Llompart, C., 1982. El Pirineo, in El Cretacico de Espana, Universidad Complutense de Madrid 4, 161-176.

Sanchez-Hernandez, Y., Maurrasse, F.J-M.R., 2014. Geochemical characterization and redox signals from the latest Barremian to the earliest Aptian in a restricted marine basin: El Pui section, Organyà Basin, south-central Pyrenees. Chemical Geology 372, 12-31.

Sanchez-Hernandez, Yosmel., 2014. Paleoenvironments and geochemical signals from the late Barremian to the middle Aptian in a Tethyan marginal basin, northeast Spain: Implications for carbon sequestration in restricted basins. Dissertation. ProQuest ETD Collection for FIU.

Sanchez-Hernandez, Y., Maurrasse, F.J.-M.R., 2016. The influence of regional factors in the expression of oceanic anoxic event 1a (OAE1a) in the semi-restricted Organyà Basin, south-central Pyrenees, Spain. Palaeogeography, Palaeoclimatology, Palaeoecology, 441, Part 3, 582-598.

Schlanger, S. O., and Jenkyns, H.C., 1976. Cretaceous Oceanic Anoxic Events: Causes and Consequences. Geologie en Mijnbouw, 55 (3-4), 179-184.

Seifert, W.K., and Moldowan, J.M., 1980. The effect of thermal stress on source-rock quality as measured by hopane stereochemistry. Physics and Chemistry of the Earth 12, 229-237. 
Socorro, Jander, Florentin J-M. R. Maurrasse, Yosmel Sanchez-Hernandez. 2017. Characterization of the negative carbon isotope shift in segment C2, its global implications as a harbinger of OAE 1a. Science China Earth Sciences, 60 (1), $30-43$.

Speranza, F., Satolli, S., Mattioli, E., Calamita, F., 2005. Magnetic stratigraphy ofKimmeridgian-Aptian sections from Umbria-Marche (Italy): new details on theM polarity sequence. Journal of Geophysical Research: Solid Earth 110, 1e26.

Stein, M., Föllmi, K.B.,Westermann, S., Godet, A., Adatte, T., Matera, V., Fleitmann, D., Berner, Z., 2011. Progressive palaeoenvironmental change during the Late BarremianeEarly Aptian as prelude to Oceanic Anoxic Event 1a: evidence from the Gorgo a Cerbara section (Umbria-Marche Basin, central Italy). Palaeogeography, Palaeoclimatology, Palaeoecology 302, 396-406.

Stein, M.,Westermann, S., Adatte, T., Matera, V., Fleitmann, D., Spangenberg, J.E. and Föllmi, K.B., 2012. Late Barremian-Early Aptian palaeoenvironmental change: the Cassis-La Bédoule section, southeast France. Cretaceous Research 37, 209-222.

Stinton, C.W. and Duncan, R.A., 1997. Potential links between ocean plateau volcanism and global ocean anoxia at the Cenomanian-Turonian boundary: Economical Geology $92,836-842$.

Taylor, A. M., Goldring, R. 1993. Description and analysis of bioturbation and ichnofabric. Journal of the Geological Society of London 150, 141-148.

Tissot, B. P., \& Welte, D. H. (1984). Petroleum formation and occurrence, 2nd ed. Berlin, Springer-Verlag, 699 p.

Tribovillard, N., Riboulleau, A., Lyons, T., Baudin, F., 2004. Enhanced trapping of molybdenum by sulfurized marine organic matter of marine origin in Mesozoic limestones and shales. Chemical Geology 213, 385-401.

Tribovillard, N., Ramdani, A., Trentesaux, A., 2005. Controls in organic accumulation in upper Jurassic shales of northwestern Europe as inferred from trace-metals geochemistry. In: Harris, N. (Ed.), The deposition of Organic-Carbon-Rich sedimenst: Model, Mechanisms, and Consequences.SEPM Special Publication 82, 145-164.

Tribovillard, N., Algeo, T.J., Lyons, T., Riboulleau, A., 2006. Trace metals as paleoredox and paleoproductivity proxies: An update. Chemical Geology 232(1-2), 12-32.

Tyson, R.V., Pearson, T.H., 1991. Modern and ancient continental shelf anoxia: an overview. In: Tyson, R.V., Pearson, T.H. (Eds.), Modern and Ancient Continental Shelf Anoxia: Geological Society of London. Special Publication 58, pp. 1-24. 
Vissers, R. L. M., D. J. J. van Hinsbergen, D. G. van der Meer., W. Spakman (2016), Cretaceous slab break-off in the Pyrenees: Iberian plate kinematics in paleomagnetic and mantle reference frames. Gondwana Research, 34, 49-59.

Wignall, P.B., Myers, K. J., 1988. Interpreting benthic oxygen levels in mudrocks: A new approach. Geology 16:452-45. 


\section{FIGURES}

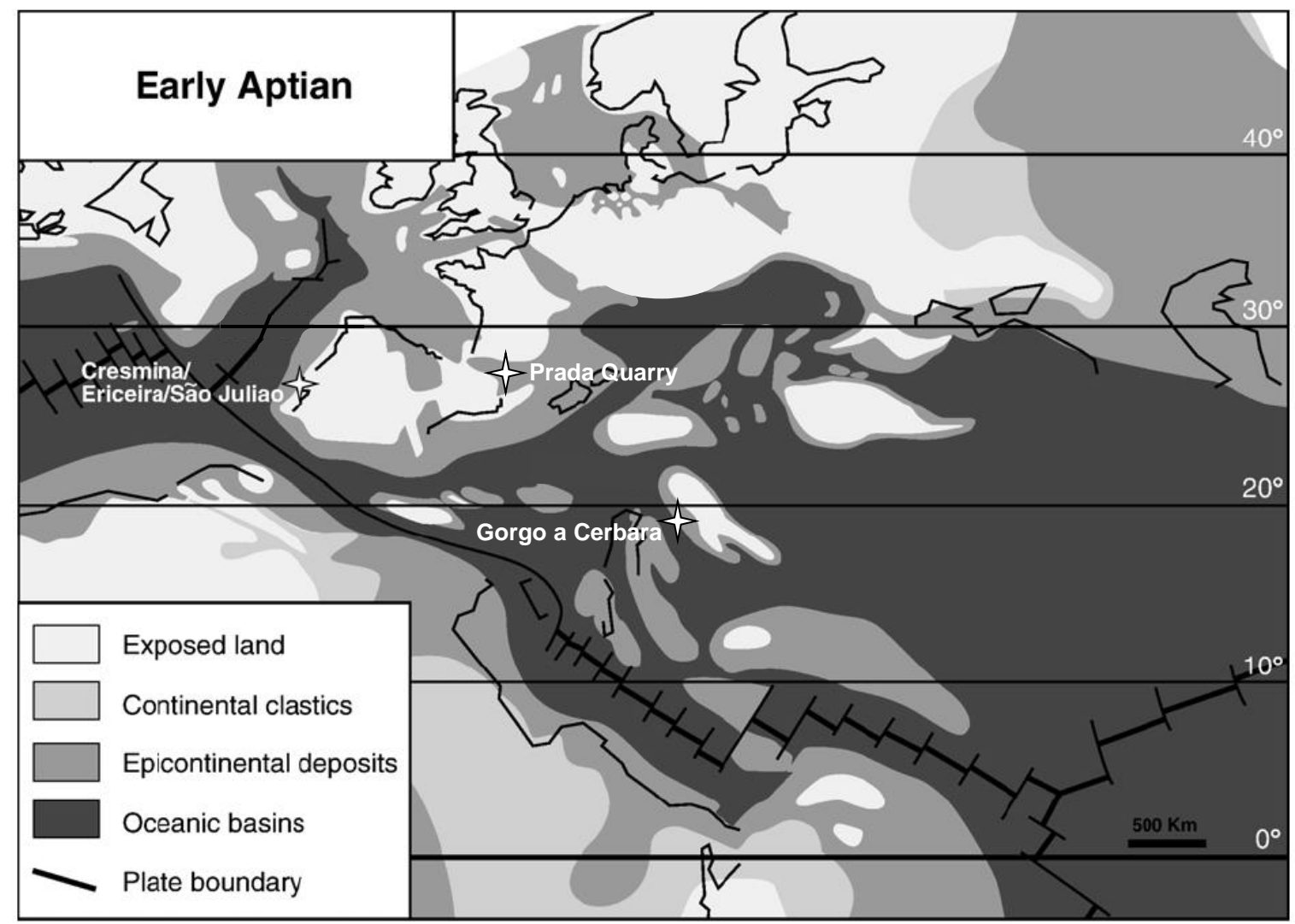

Figure 1. Paleogeographic reconstruction of the Tethyan realm during the mid-Cretaceous at $\sim 115 \mathrm{Ma}$. Asterisks mark location of Cresmina, Gorgo a Cerbara, and Prada Quarry sections. Map taken from Burla et al. (2008), originally from Masse et al. (2000). 


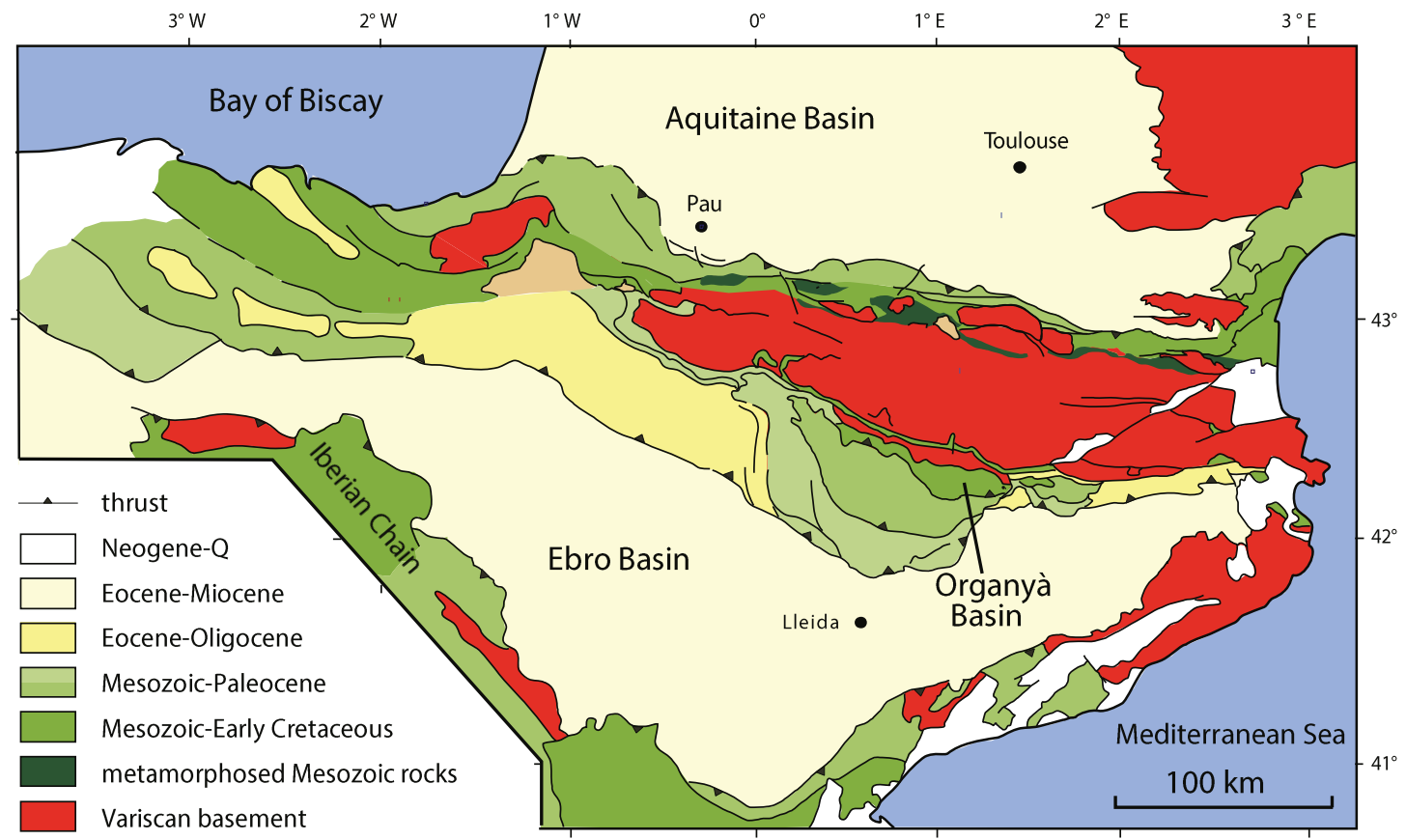

Figure 2. Geological map of the Pyrenees including location of Organyà Basin. Modified after Vissers et al., (2016). 


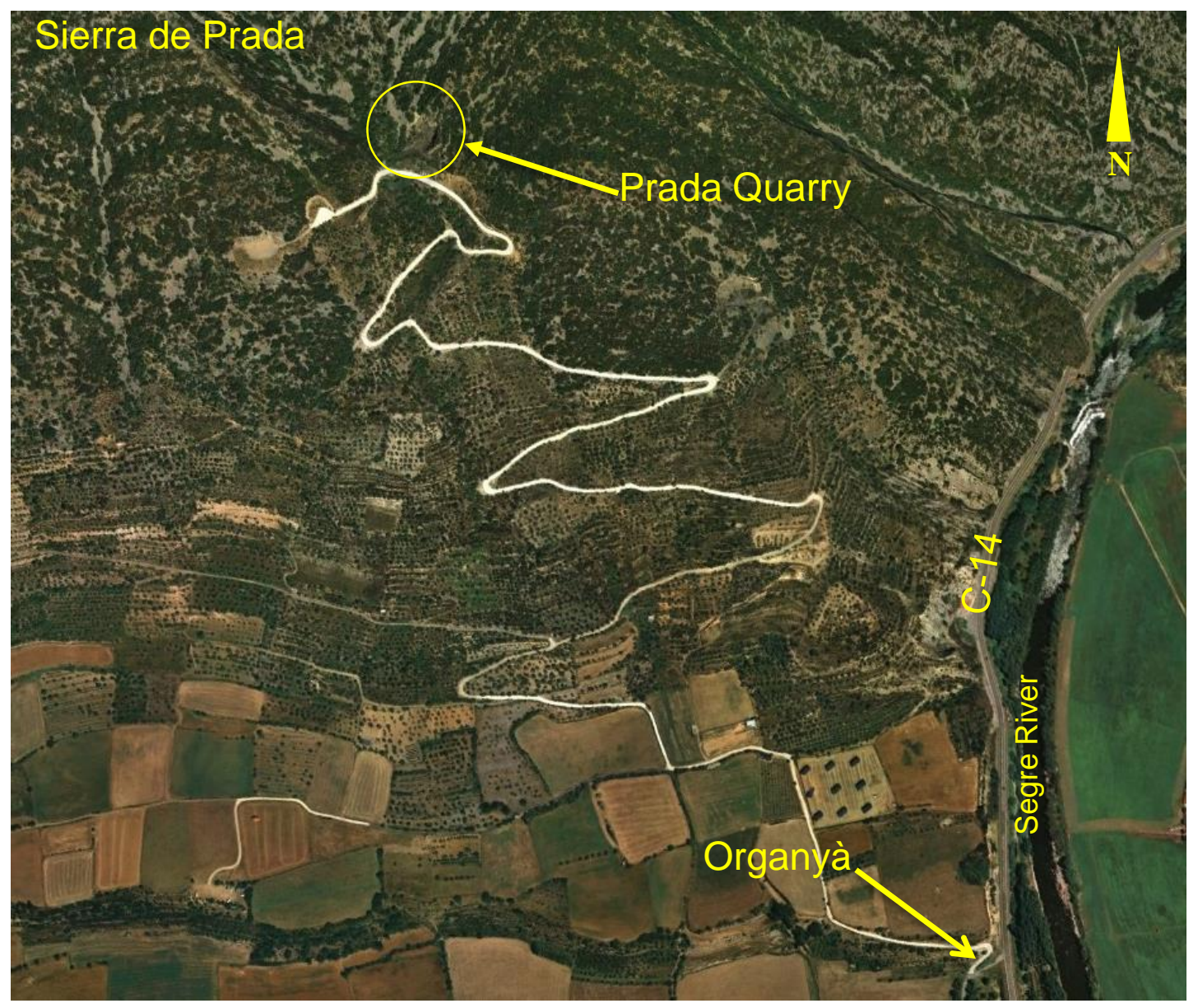

Figure 3. Sierra de Prada: south flank showing position of Prada Quarry. Quarry accessible off the road leading to the municipal skydiving platform (Envol Organyá) on the south flank of the Sierra de Prada overlooking the Cabó River valley. Google Earth images dated 31 Dec. 2008. 

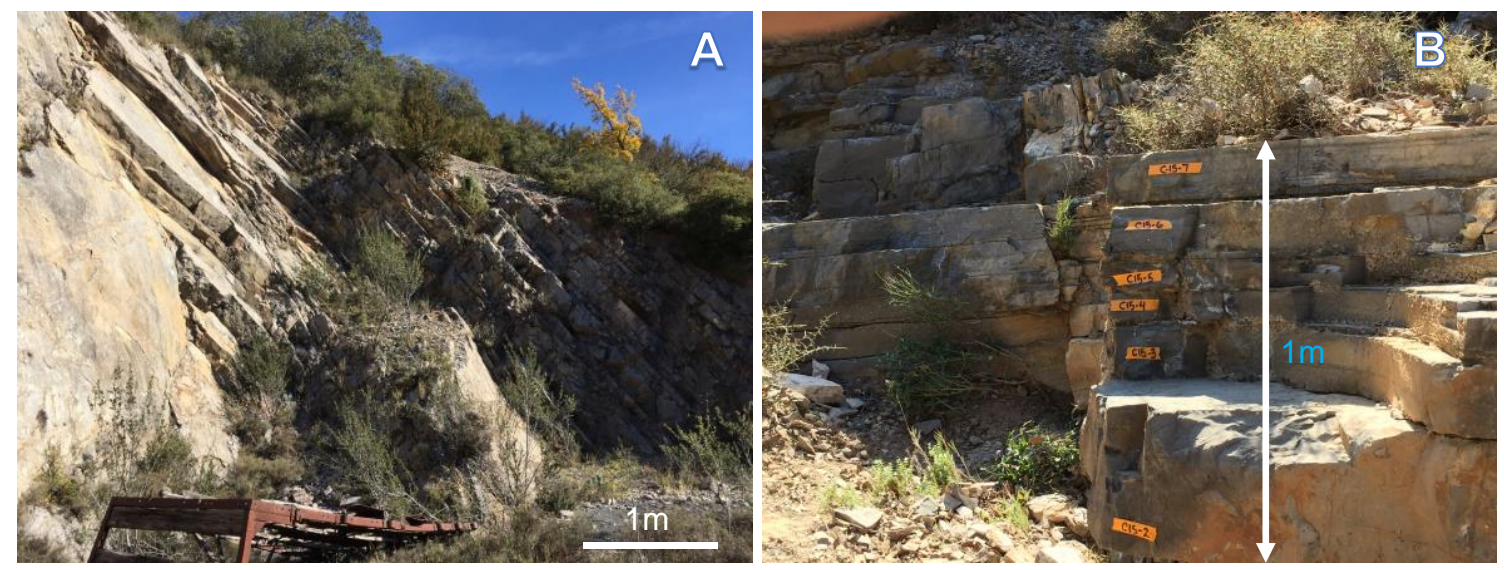

Figure 4. A) Field view of the upper $15 \mathrm{~m}$ of the eastern Prada Quarry section showing the beds dipping southward which allowed to easily follow the superposition of the succession along the quarry cut. B) View of sampling interval marked by orange tape shows nature of beds within lower $1 \mathrm{~m}$ (sediment thickness). 


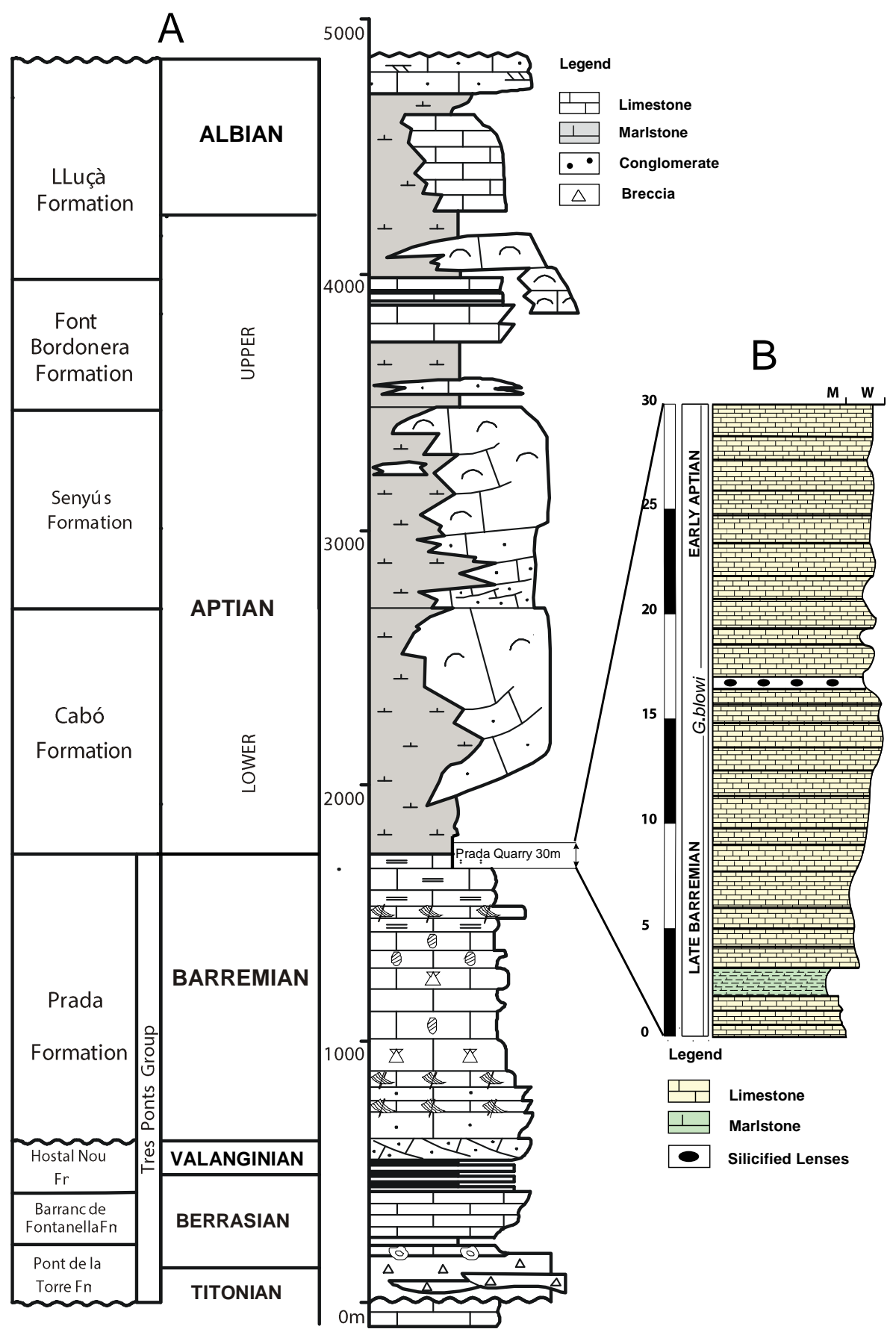

Figure 5. A) Stratigraphic column of the lower Cretaceous of the Organyà Basin (modified from GarcíaSenz, 2002), as proposed by Sanchez-Hernandez and Maurrasse, (2014). B) Chronostratigraphic column of the $30 \mathrm{~m}$ studied at the Prada Quarry with lithologic characterization. Facies studied in the Prada Quarry section correspond to the mudstone classification of Dunham (1962). 


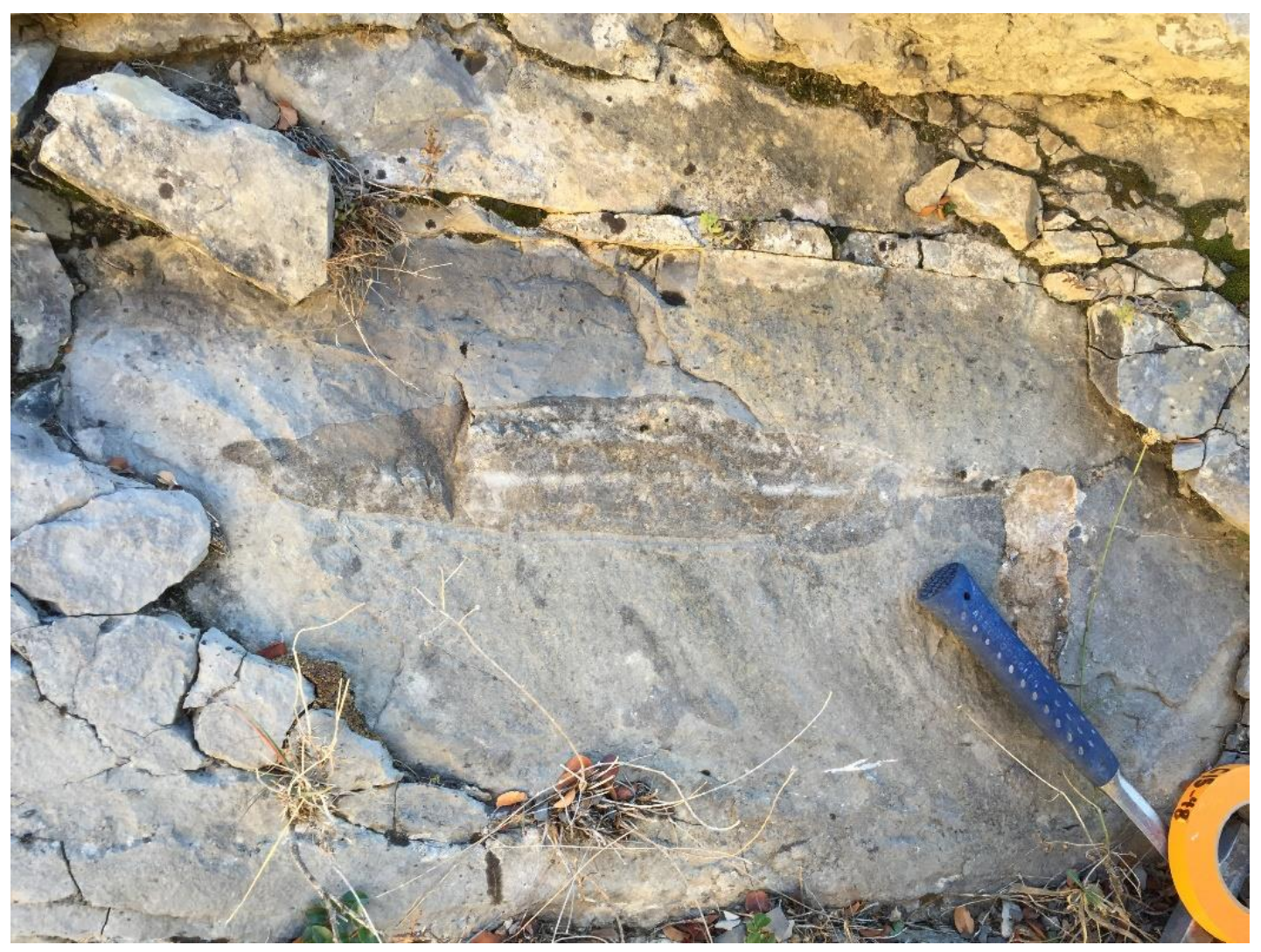

Figure 6. Image of a silicified lens observed at the $16.45 \mathrm{~m}$ level stratigraphic level of the Prada Quarry section (CC-15-45). Hammer for scale (blue handle length $15 \mathrm{~cm}$ ). 


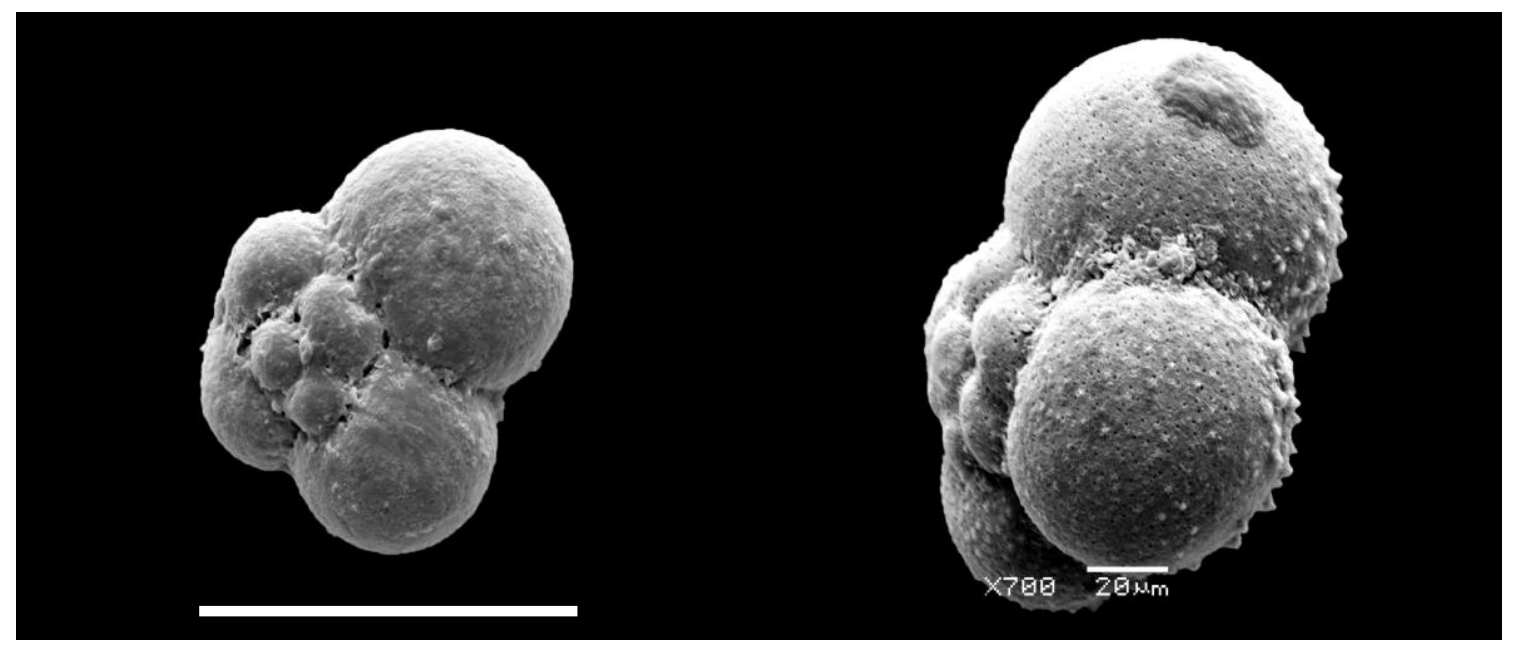

Figure 7. SEM images of two different specimens of Hedbergella sigali Moullade 1966 obtained from sample CC-15-18. Scale bar 100 microns where not specified. 

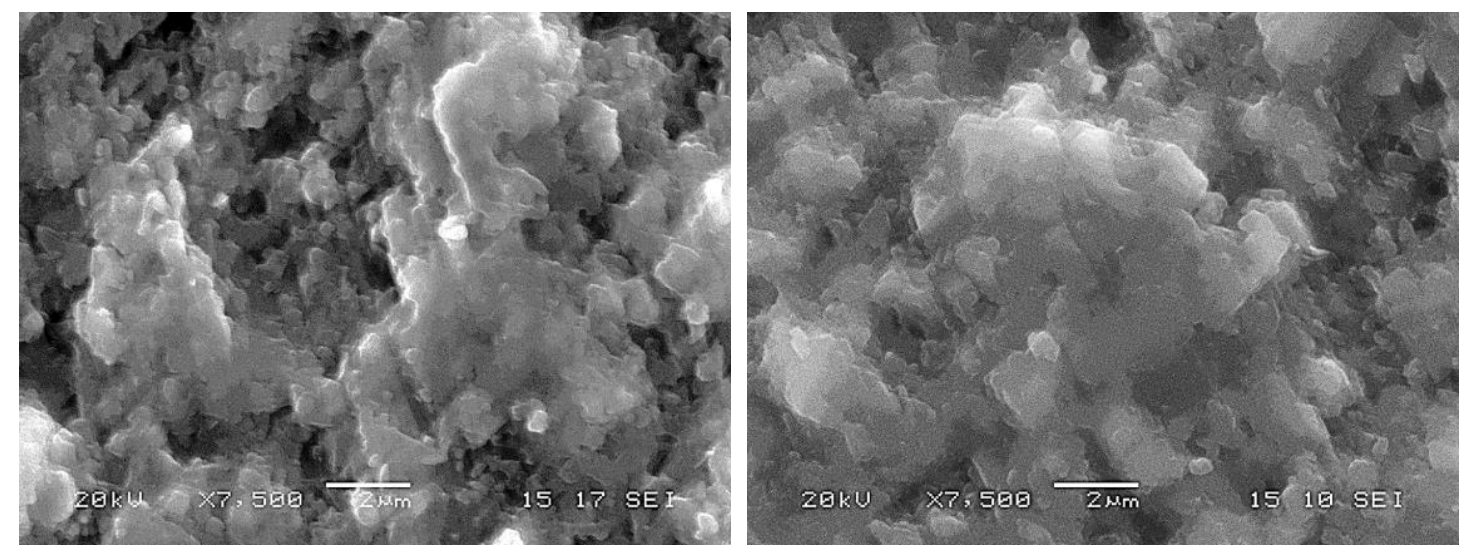

Figure 8. SEM images obtained from thin section of sample CC-15-05 illustrate a significant contribution of disaggregated nannoconids fragments to the matrix. 


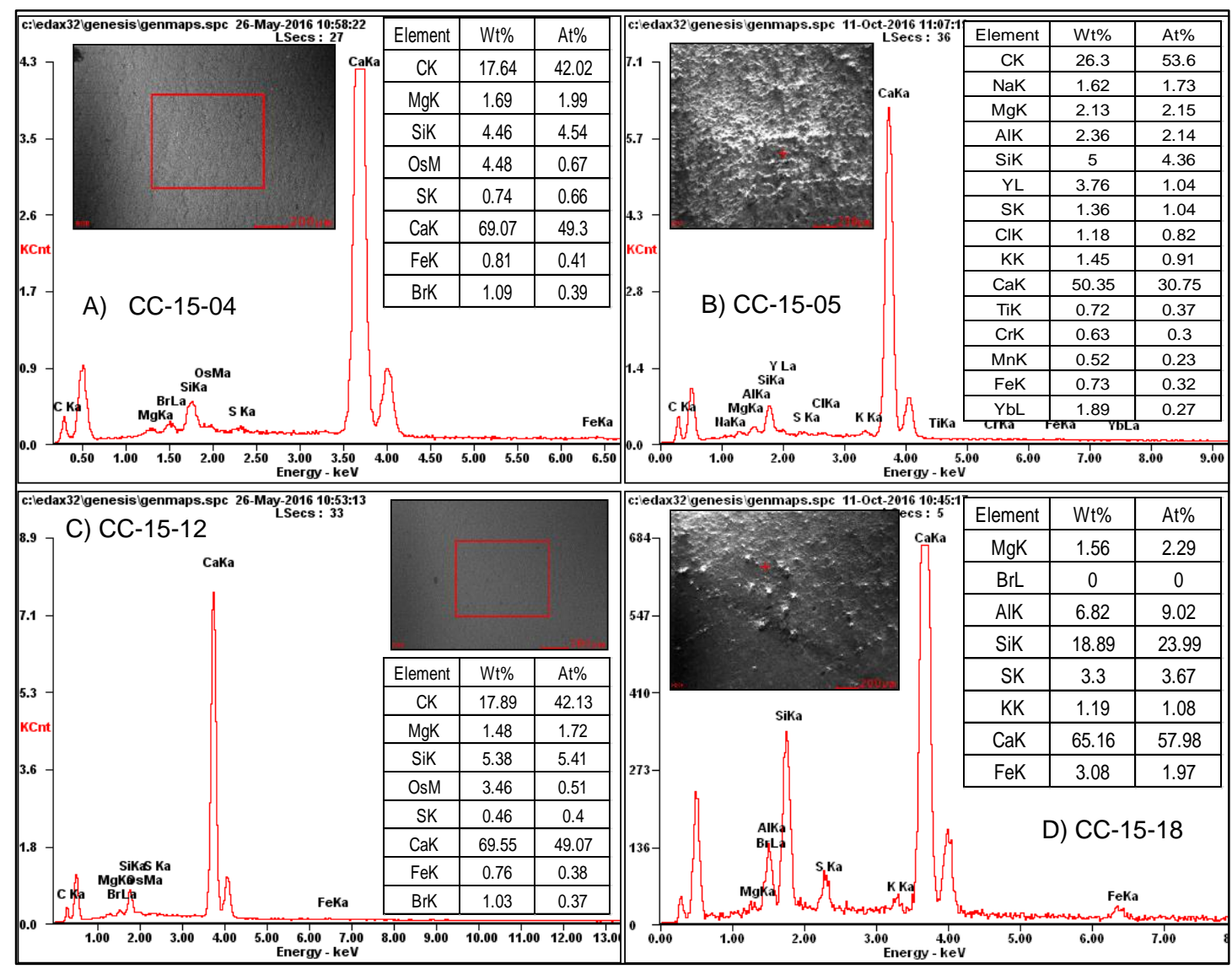

Figure 9. SEM/EDS elemental diagrams of analyses performed on thin sections of the Prada Quarry section showing qualitative composition of red square areas of samples: (A) Sample CC-15-04. (B) Sample CC-15-05. (C) Sample CC-15-12 (D) Sample CC-15-18. The texture of the fine matrix and the isotropic distribution of grains are seen in micrographs on backscattered electron mode (BSE). 


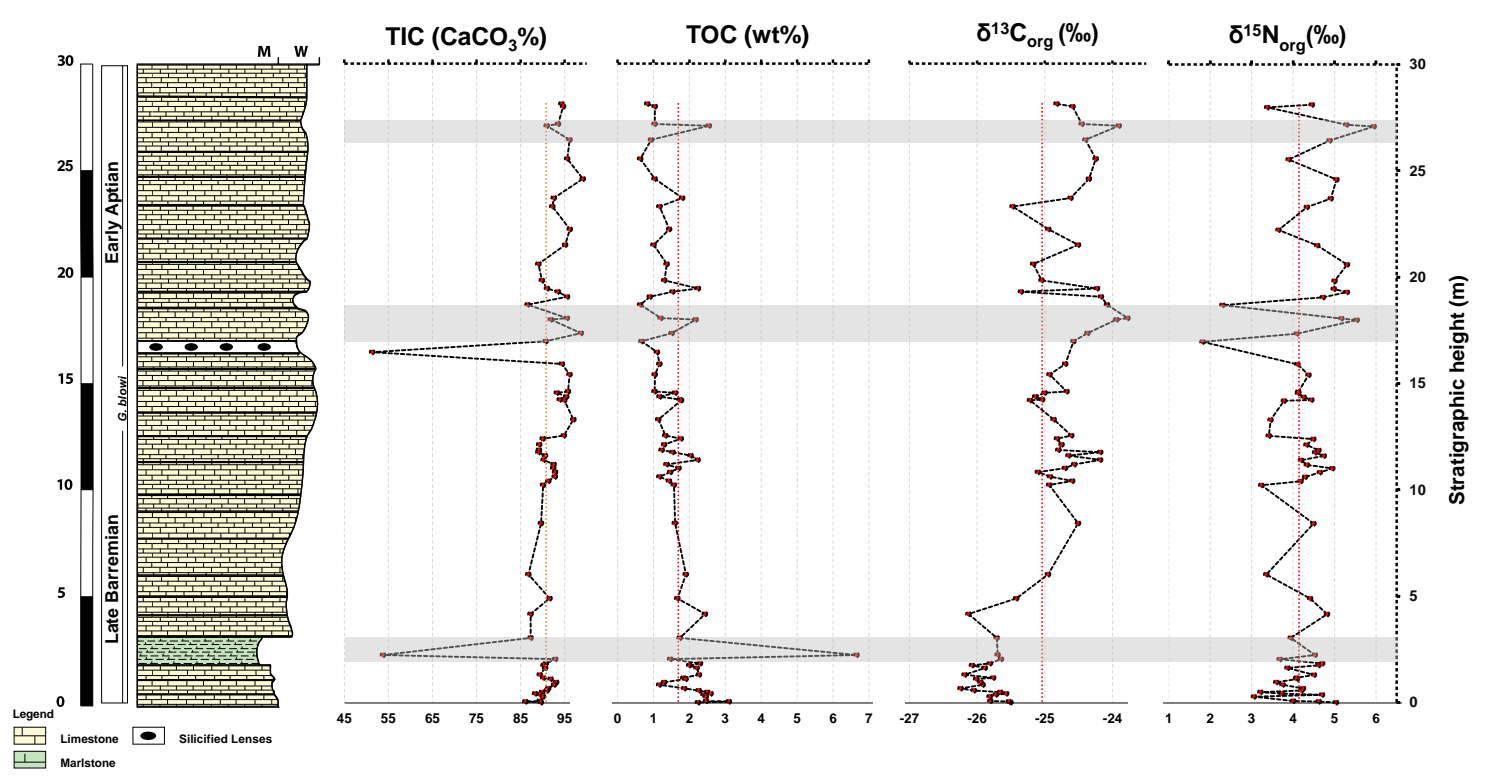

Figure 10. Chemostratigraphy of the Prada Quarry section showing temporal variations in: TIC, TOC, Carbon and Nitrogen isotope values. Light grey bands indicate positive correlation between TOC, Carbon and Nitrogen isotopes versus TIC. Red dashed lines representing background values are plotted for reference. 


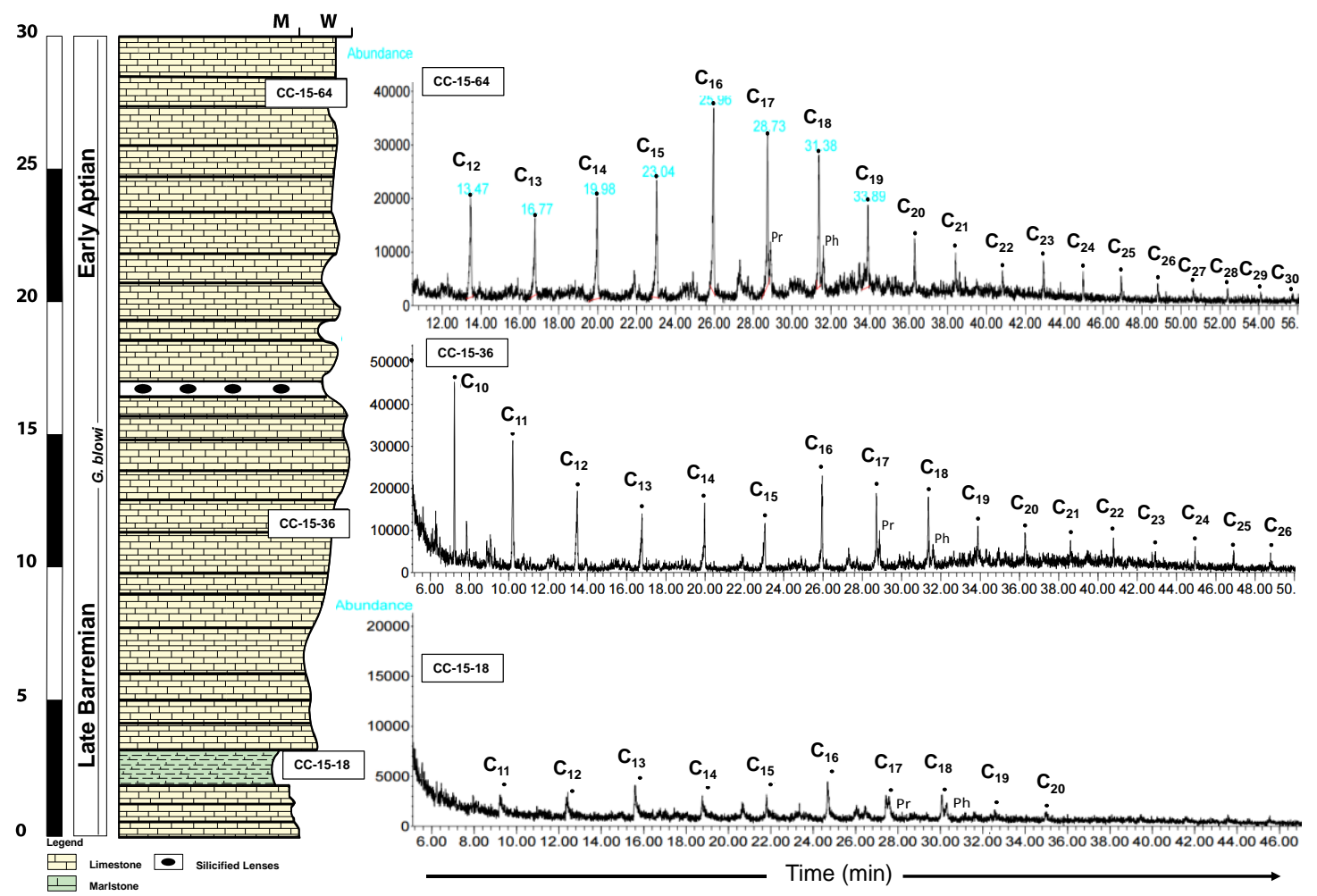

Figure 11. Lithostratigraphy of the Prada Quarry section and chromatographs of molecular biomarkers $n$ alkane distribution measured in 3 samples corresponding to different levels. Compounds exhibiting carbon chain lengths $>20$ indicate OM from terrestrial origin incorporated to the basin. Compounds with lengths $<20$ indicate in situ origin of OM from phytoplankton. 


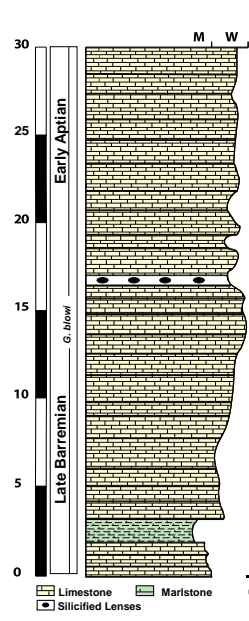

Al (ppm)

Si (ppt)

Ti (ppm)
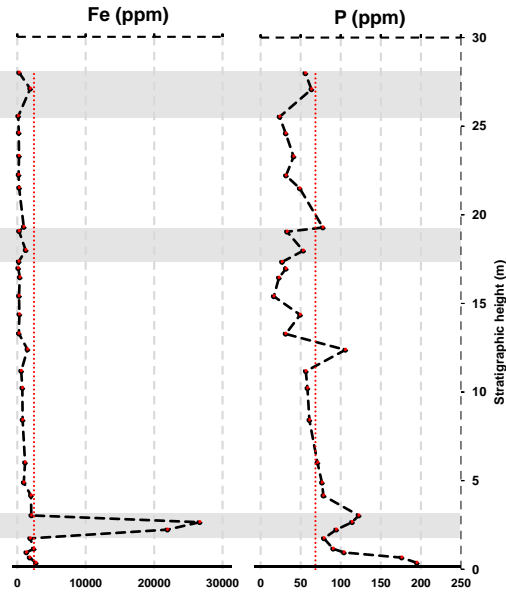

Figure 12. Chemostratigraphic diagram including, major and biolimiting elements of the Prada Quarry section and their concentrations in ppm ( $\mathrm{Si}$ in parts per thousand). Red dashed lines included show background levels. 


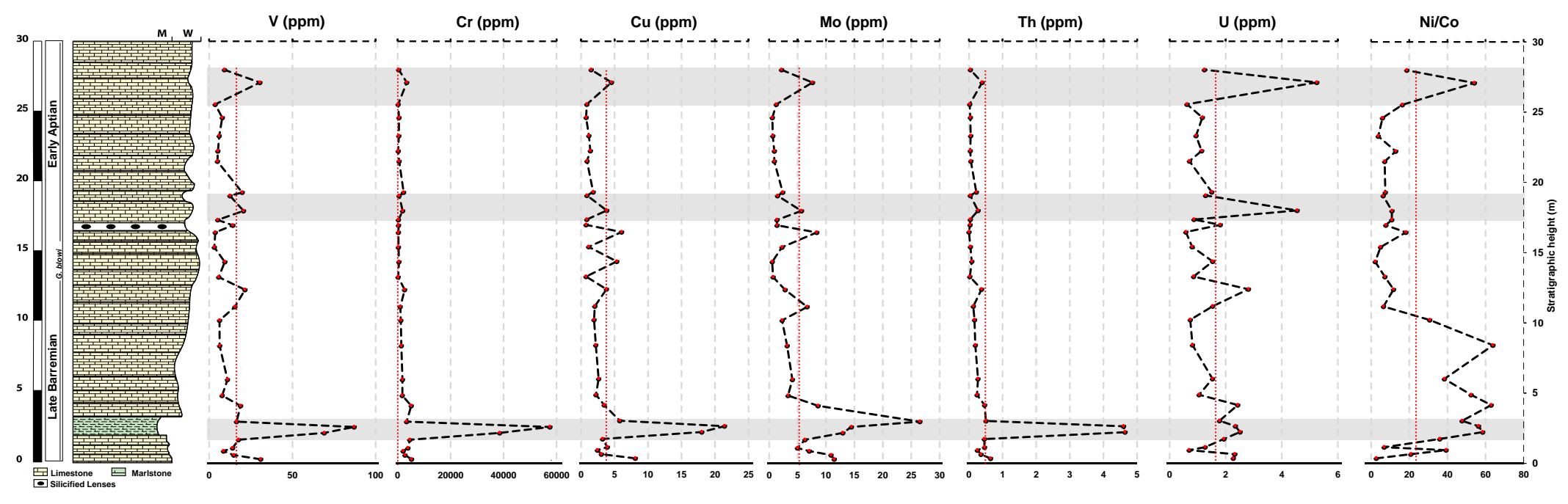

Figure 13. Chemostratigraphic diagram including, redox-sensitive trace elements

of the Prada Quarry section and their concentrations in ppm. Red dashed lines are plotted to indicate background levels. 


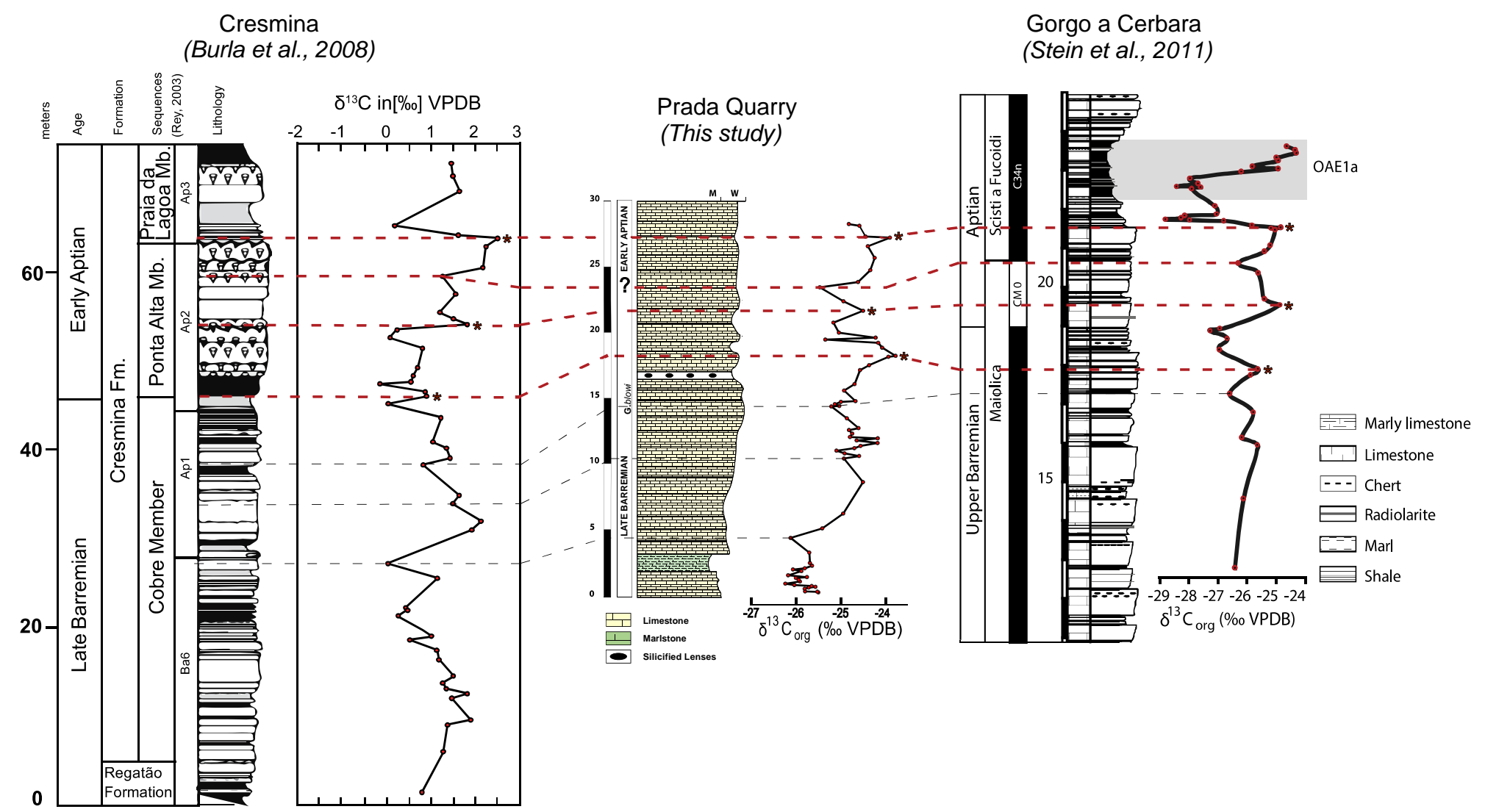

Figure 14. Carbon isotope correlation based on data for three sections. From left to right Cresmina section from the North Atlantic (Burla et al., 2003); Prada Quarry section from the Organyà Basin (Tethys) (this study); and, Gorgo a Cerbara section (Tethys) (Stein et al., 2011). Asterisks (3) show common data points at positive shifts in the $\delta^{13} \mathrm{C}$ curves used for correlation. Segment boundaries (red dashed lines) are established by inflection patterns and/or changing gradients of the carbon isotope curve that show distinct trends allowing approximate correlation. 


\section{PLATES}

PLATE 1. Microphotographs of facies of the Prada Quarry section corresponding to different stratigraphic levels.

A) Microphotograph of fine micritic matrix (mudstone) of sample CC-15-09 mag 10X non-polarized scale bar 100 microns. Level $0.83 \mathrm{~m}$.

B) Microphotograph of fine micritic matrix of sample (mudstone) CC-15-21 mag 10X non-polarized scale bar 100 microns. Level $4.88 \mathrm{~m}$.

C) Microphotograph of fine micritic matrix of sample (mudstone) CC-15-29 mag 10X non-polarized scale bar 100 microns. Level $11.18 \mathrm{~m}$.

D) Microphotograph of biomicritic matrix of sample (wackestone) CC-15-45 mag 10X non-polarized scale bar 100 microns. Level $16.45 \mathrm{~m}$.

E) Microphotograph of biomicritic matrix of sample (wackestone) CC-15-50 mag 10X non-polarized scale bar 100 microns. Level $18.68 \mathrm{~m}$.

F) Microphotograph of biomicritic matrix of sample (wackestone) CC-15-64 mag 10X non-polarized scale bar 100 microns. Level $27.16 \mathrm{~m}$. 


\section{PLATE 1}
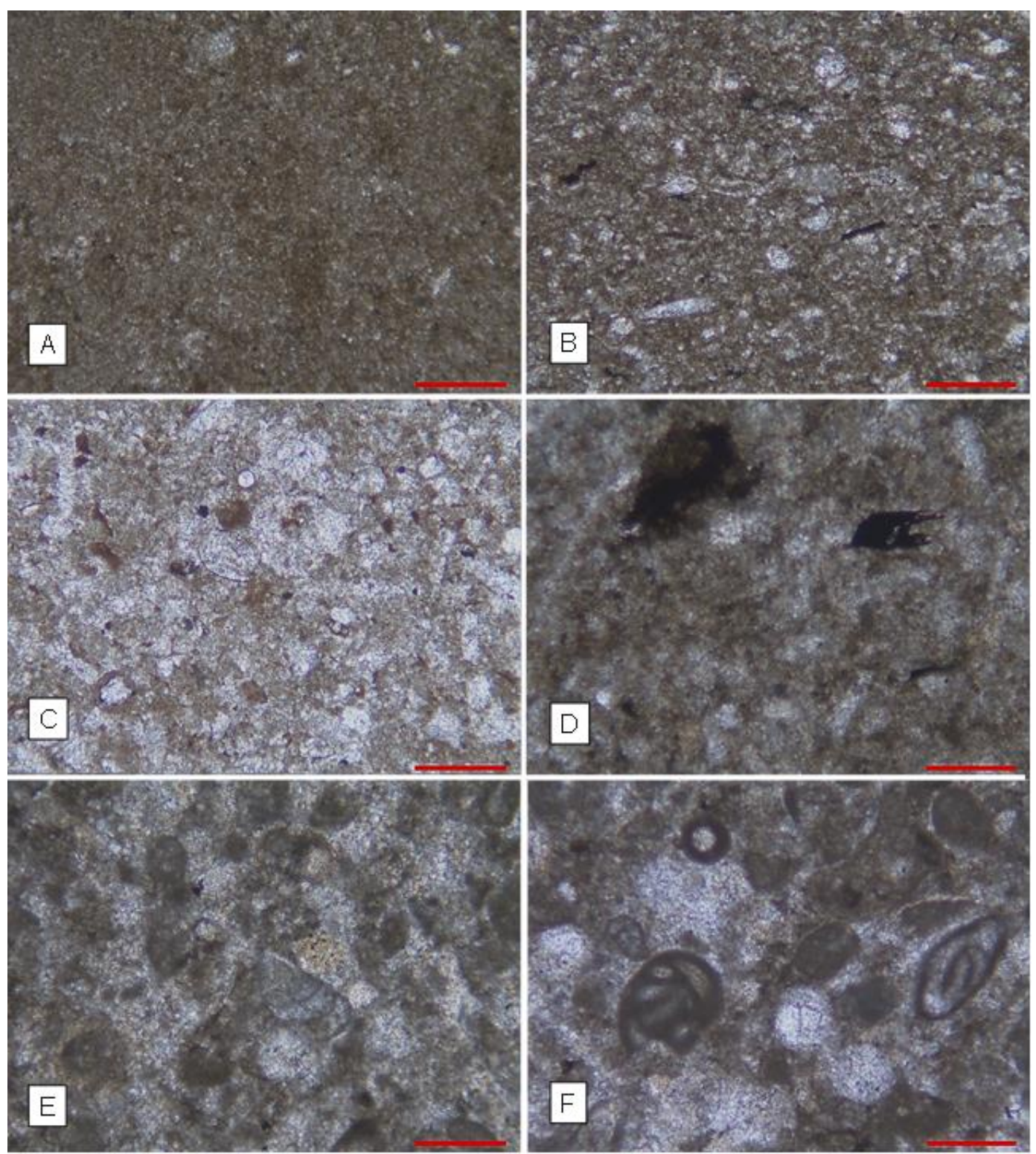
PLATE 2. Microphotographs of slides CC-15-09 and CC-15-38.

A) Shell debris from bivalves CC-15-09 10X scale bar 100 microns in fine micritic matrix.

B) Gastropod in sample CC-15-09 4X scale bar 200 microns in fine micritic matrix.

C) Bivalve shell debris in sample CC-15-09 4X scale bar 200 microns in fine micritic matrix.

D) Bivalve shell debris in sample CC-15-09 4X scale bar 200 microns in fine micritic matrix.

E) Gastropod in sample CC-15-09 4X scale bar 200 microns in fine micritic matrix.

F) Bivalve shell fragment in sample CC-15-38 4X scale bar 200 microns in fine micritic matrix. 
PLATE 2
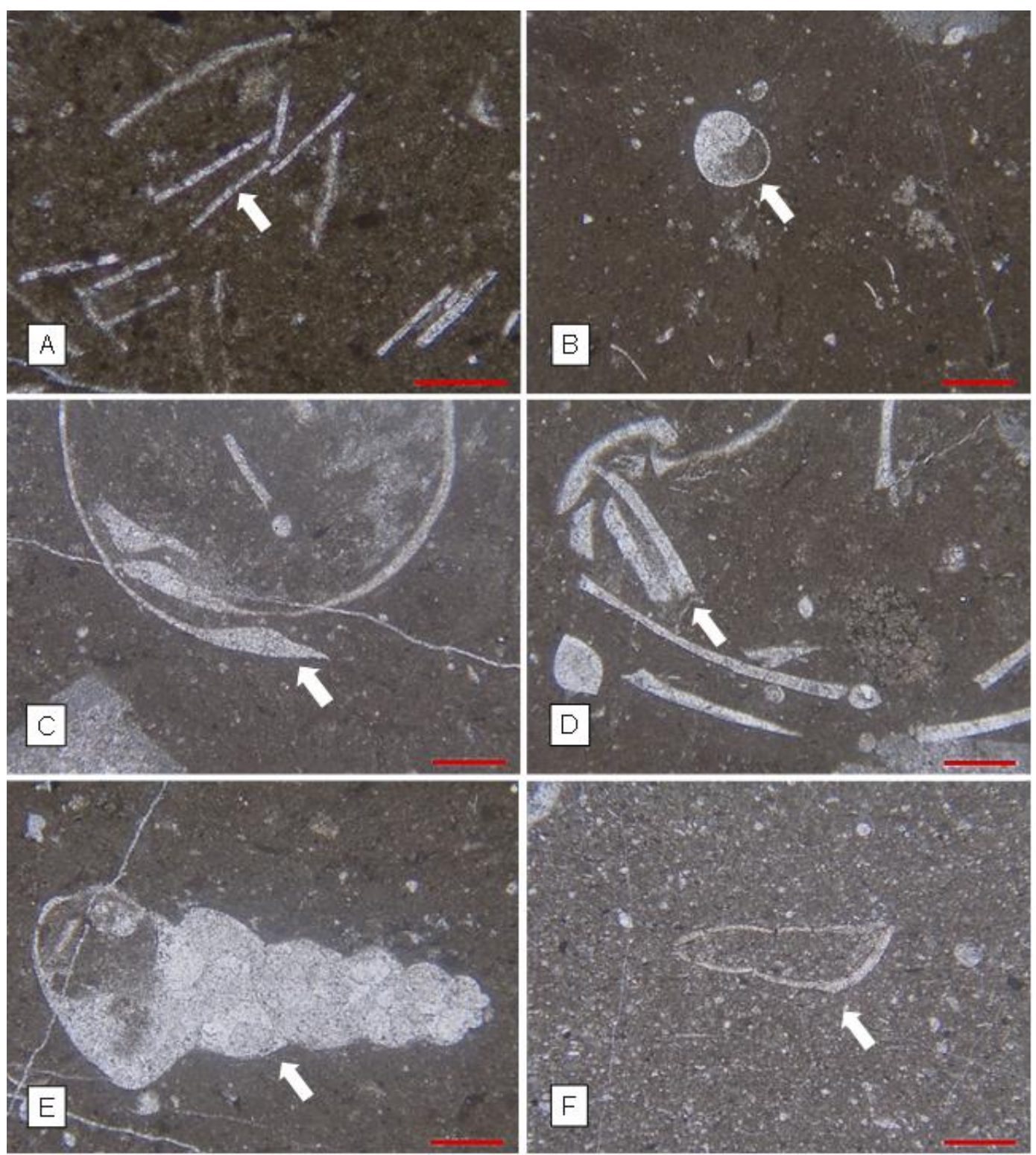
PLATE 3. SEM images of benthic and planktic foraminifera obtained from sample CC-15-18.
A) SEM image of foraminifer Hedbergella sigali Moullade 1966. Scale bar 100 microns where not specified.
B) Arenobulimina sp.
C) Neotrocholina sp?
D) Spirillina sp? Agglutinated specimen.
E) Miliolid foraminifer.
F) Benthic foraminifer. 
PLATE 3

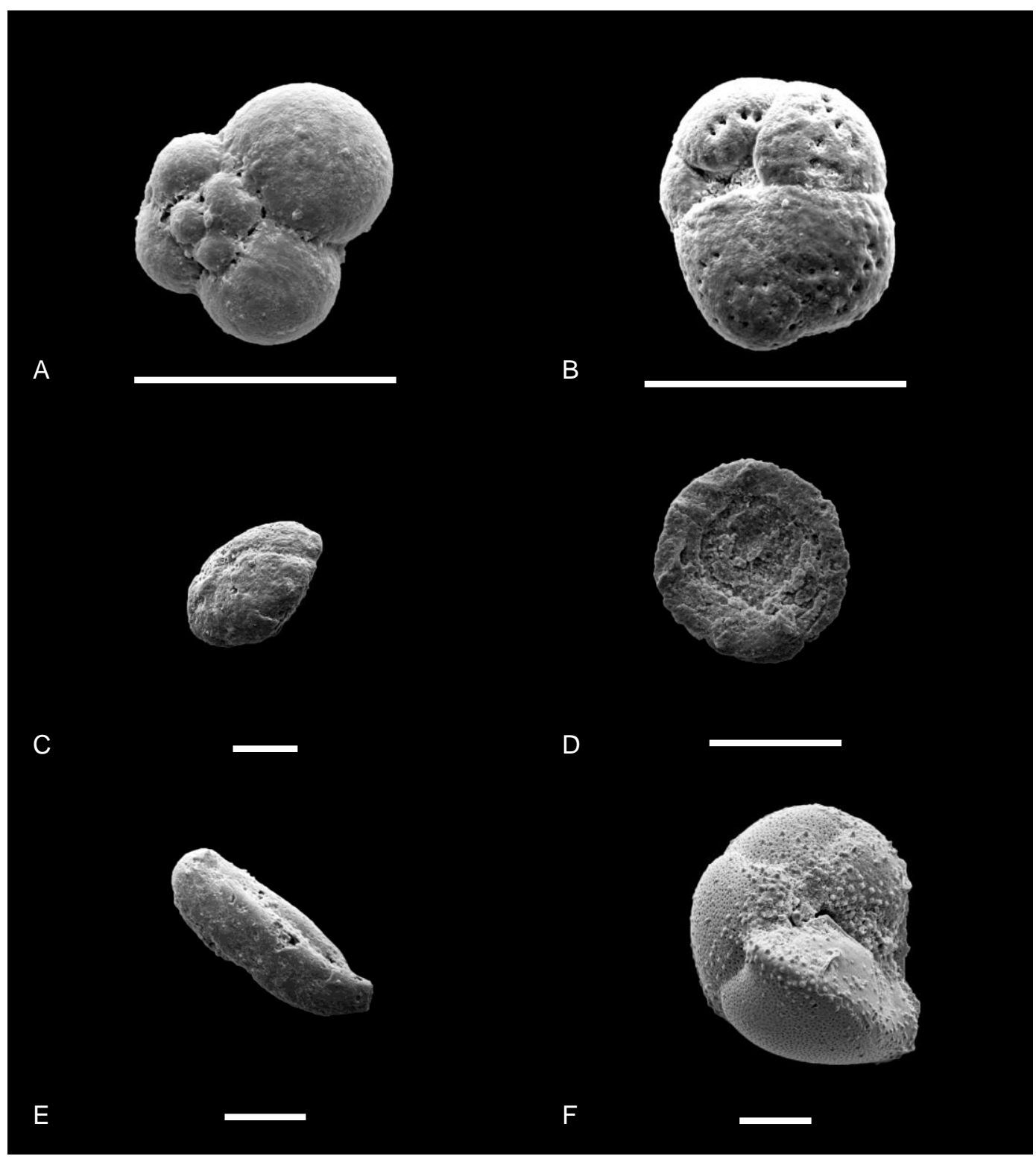


PLATE 4. SEM images of foraminifera obtained from sample CC-15-18.

A) Miliolid.

B) Neotrocholina sp.

C) Nezzazatinella $\mathrm{sp}$

D) Lagenid.

E) Hedbergella sigali Moullade.

F) Hedbergella sigali Moullade. 
PLATE 4

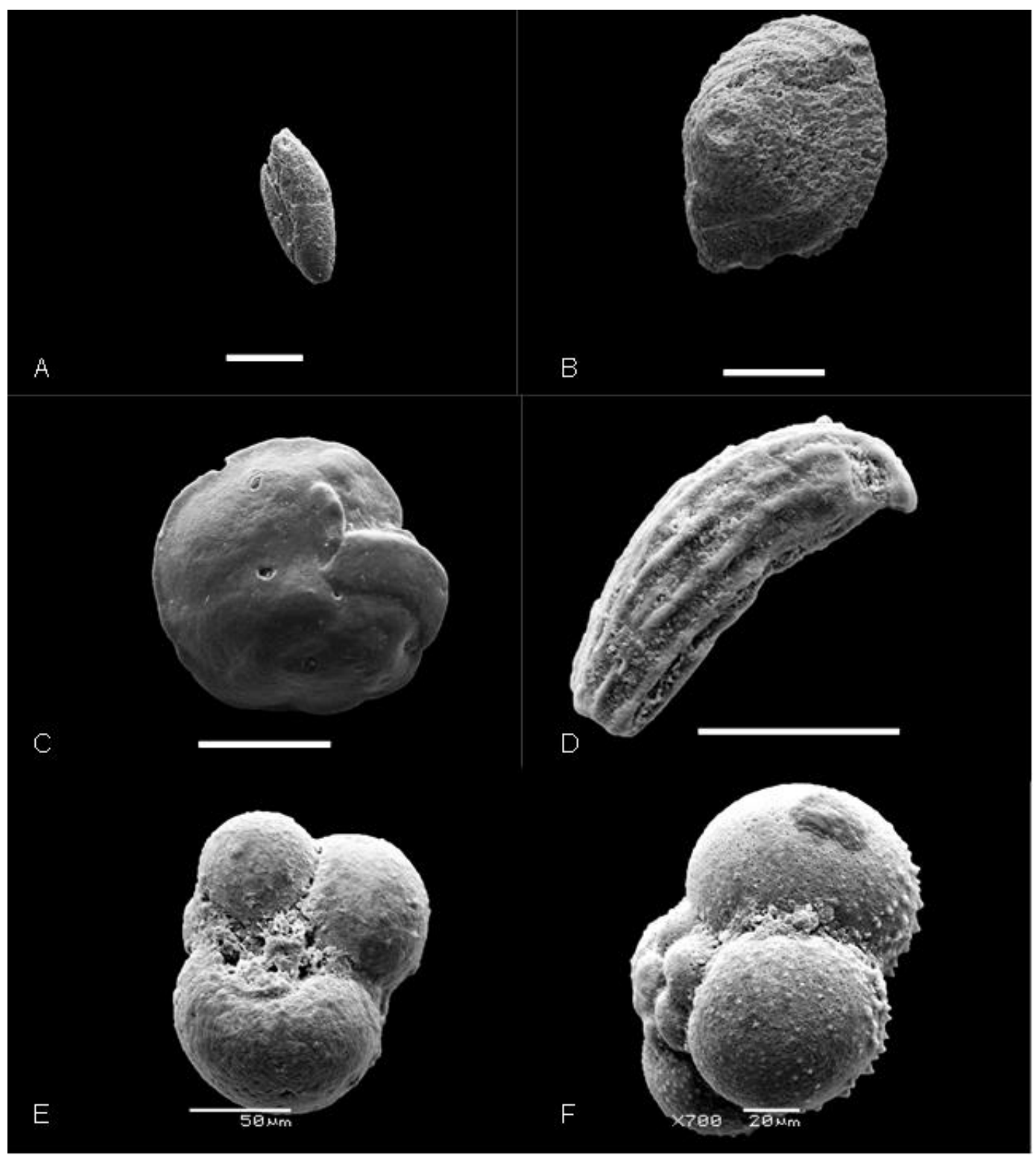


PLATE 5. SEM images of organisms and biogenic fragments obtained from sample CC15-18, CC-15-50, and CC-15-63.
A) Uniserial benthic foraminifer. Specimen from sample CC-15-18
B) Orbiculiforma sp? Radiolarian specimen from sample CC-15-63.
C) Gastropod skeletal fragment sample CC-15-50
D) Orbiculiforma sp? Radiolarian specimen from sample CC-15-63.
E) Bioclast from sample CC-15-50.
F) Calcified sponge spicule from sample CC-15-50. 


\section{PLATE 5}

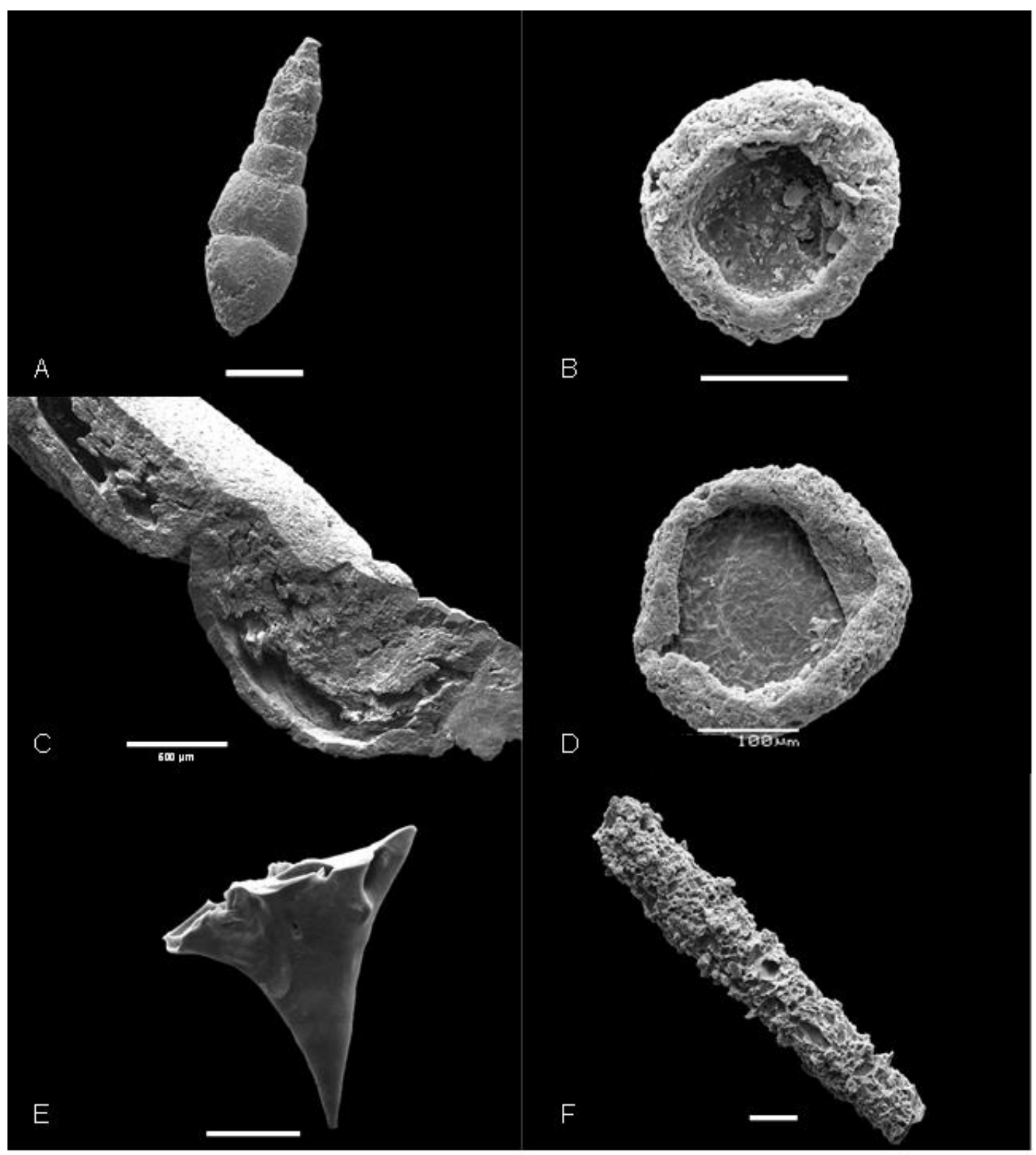


PLATE 6. Microphotographs of slides CC-15-49, CC-15-63, CC-15-64, and CC-15-65.

A) Organic matter in the form of higher plant remains in sample CC-15-63 10X scale bar 100 microns.

B) Calcified sponge spicule in sample CC-15-49 4X scale bar 200 microns.

C) Calcified sponge spicules in sample CC-15-64 scale bar 200 microns.

D) Ostracod in sample CC-15-65 10X scale bar 100 microns.

E) Miliolid foraminifer. Sample CC-15-64 10X scale bar 100 microns.

F) Miliolid foraminifer. Sample CC-15-64 10X scale bar 100 microns. 
PLATE 6
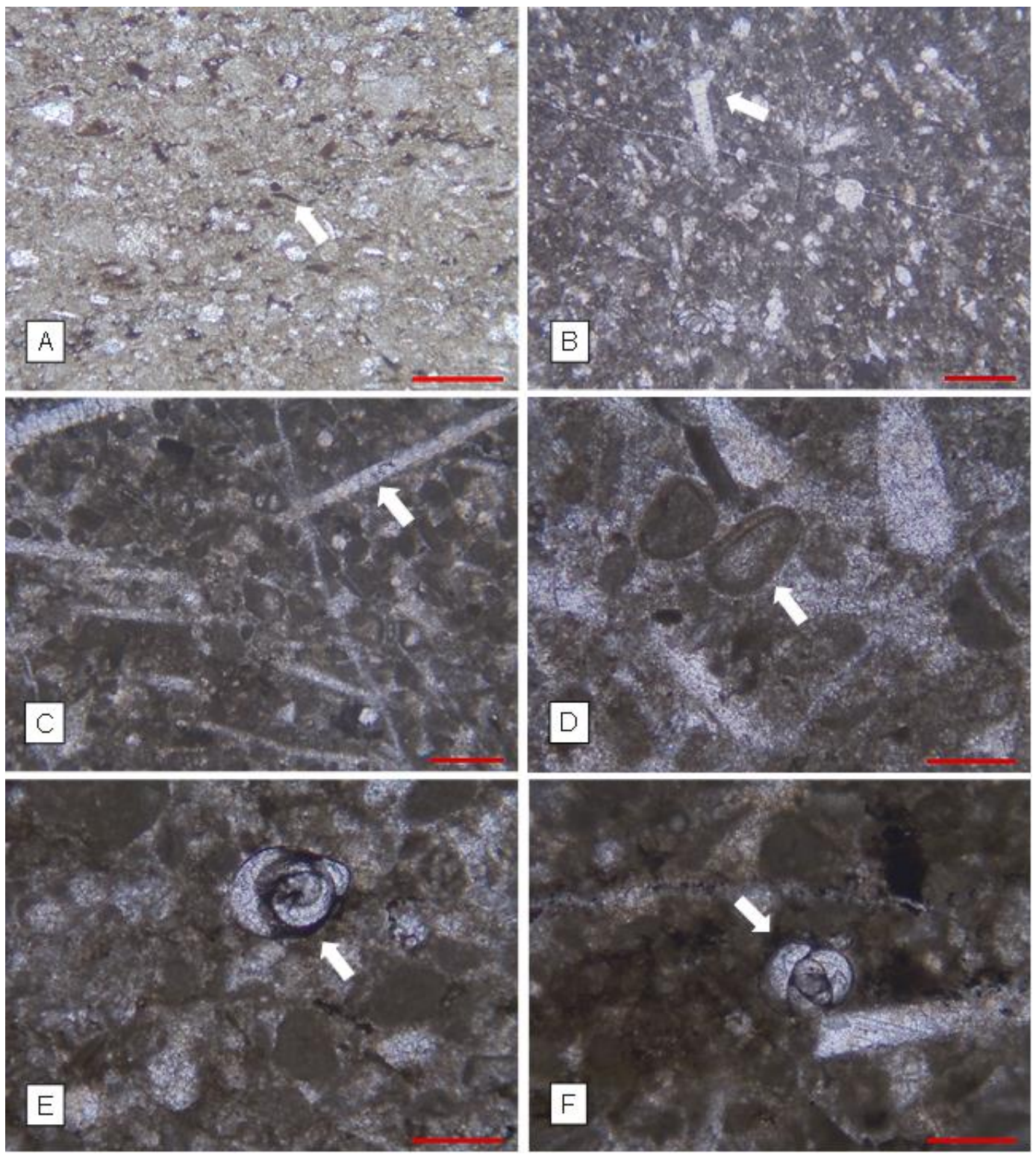
PLATE 7. Microphotographs of slide CC-15-64.
A) Glomospira sp Sample CC-15-64 10X scale bar 100 microns.
B) Arenobulimina sp? Sample CC-15-64 10X scale bar 100 microns.
C) Skeletal fragment of benthic organism in sample CC-15-64 10X scale bar 100 microns.
D) Triloculina sp? Sample CC-15-64 10X scale bar 100 microns.
E) Spiroloculina sp? Sample CC-15-64 10X scale bar 100 microns.
F) Benthic foraminifer. Sample CC-15-64 10X scale bar 100 microns. 


\section{PLATE 7}
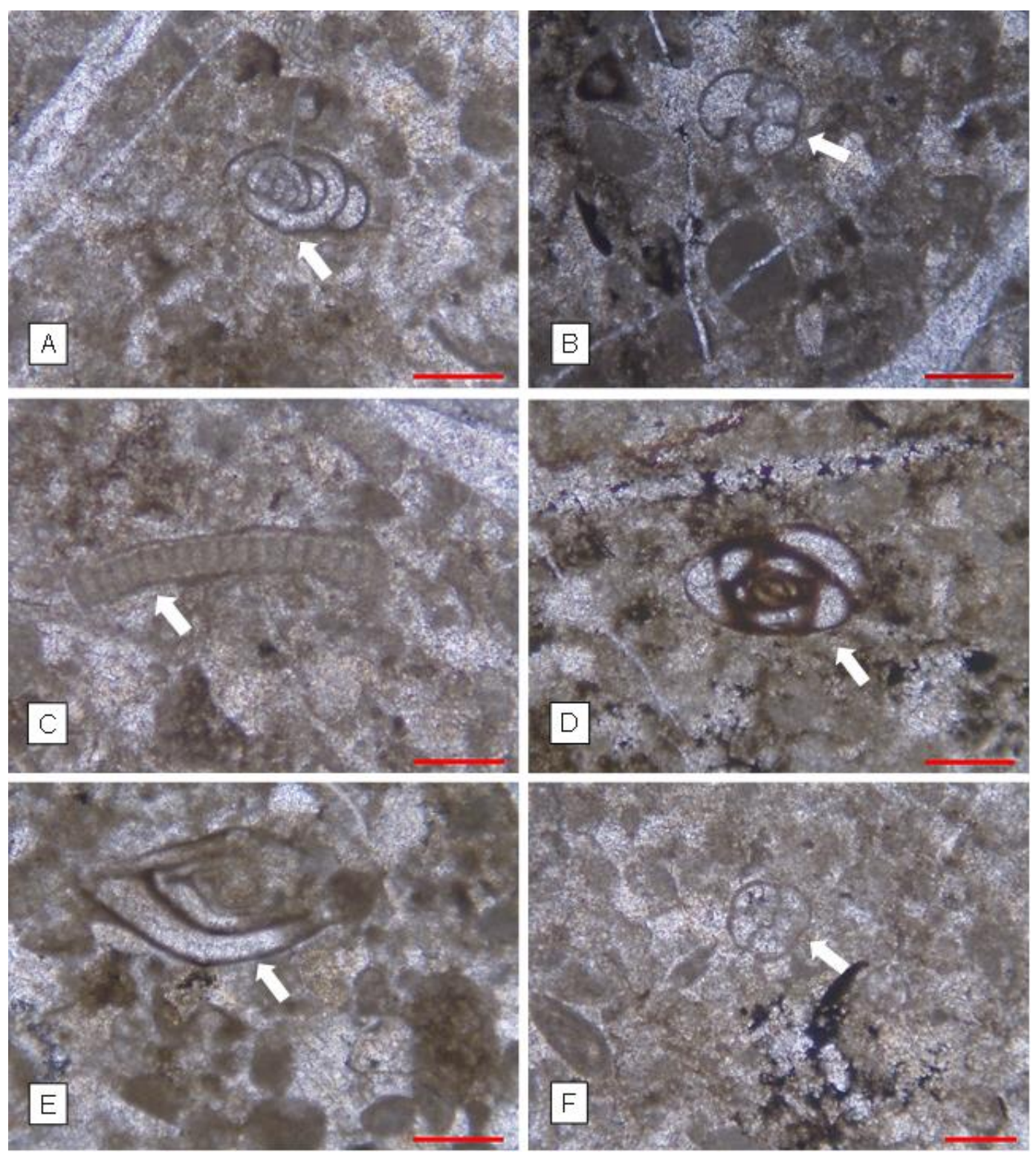
PLATE 8. Microphotographs of slides CC-15-12, CC-15-33, CC-15-39, CC-15-43, and CC-15-50.
A) Benthic foraminifer in sample CC-15-43 4X scale bar 200 microns.
B) Globigerinelloides blowi Bolli 1959 in sample CC-15-33 10X scale bar 100 microns.
C) Cluster of serpulid worm tubes in sample CC-15-50 10X scale bar 200 microns.
D) Foraminifer in sample CC-15-39 4X scale bar 200 microns.
E) Foraminifer in sample CC-15-39 scale bar 200 microns.
F) Ostracod fragment in sample CC-15-12 10X scale bar 100 microns. 
PLATE 8
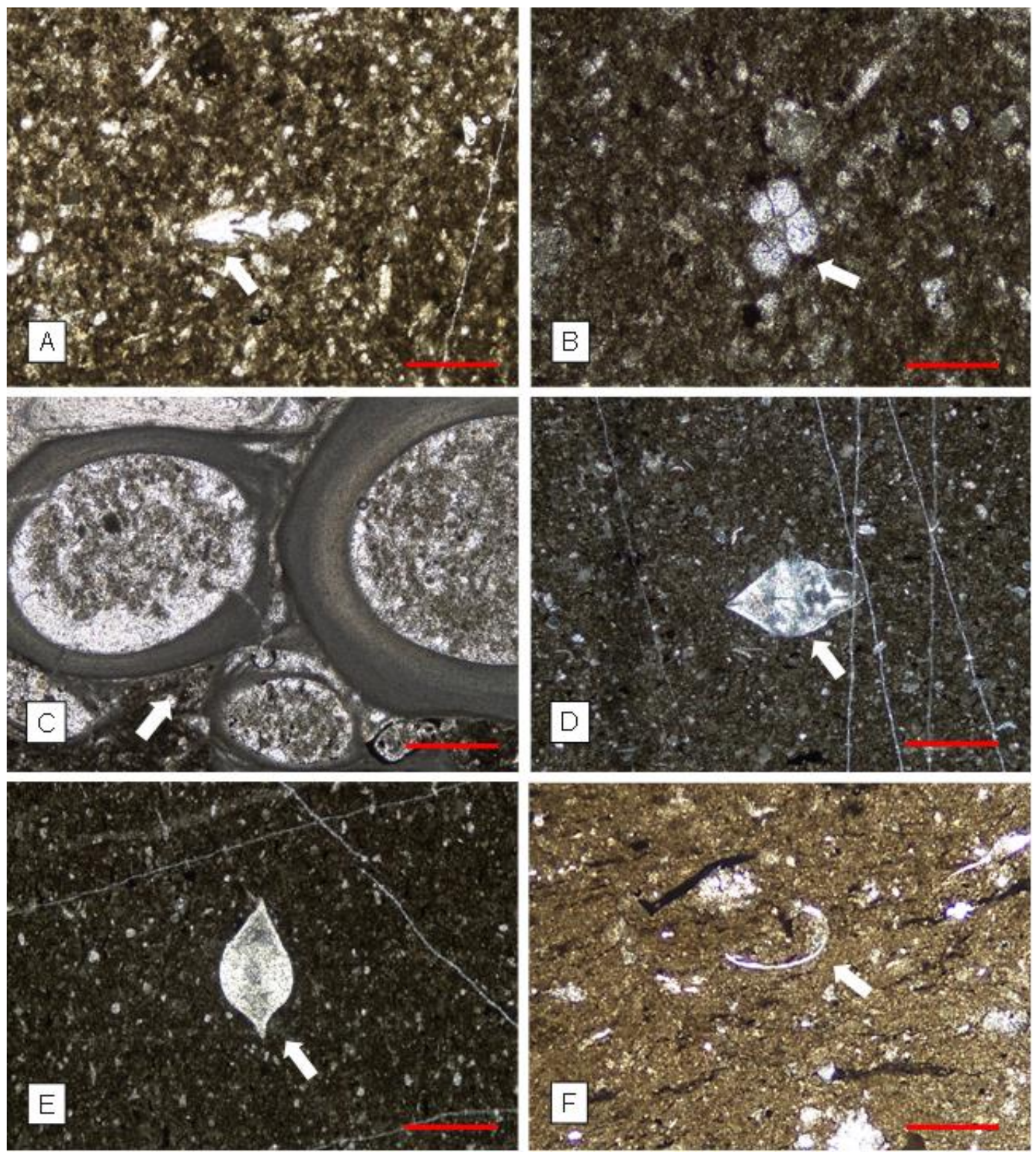
PLATE 9. SEM images of specimens, biogenic and non-biogenic fragments CC-15-18, CC-15-42, CC-15-58, and CC-15-63.
A) Higher plant material from sample CC-15-63.
B) Higher plant material from sample CC-15-58
C) Quartz crystal from sample CC-15-42
D) Higher plant material from sample CC-15-58
E) Spumellarian radiolarian from sample CC-15-18.
F) Framboidal pyrite from sample CC-15-18. 
PLATE 9

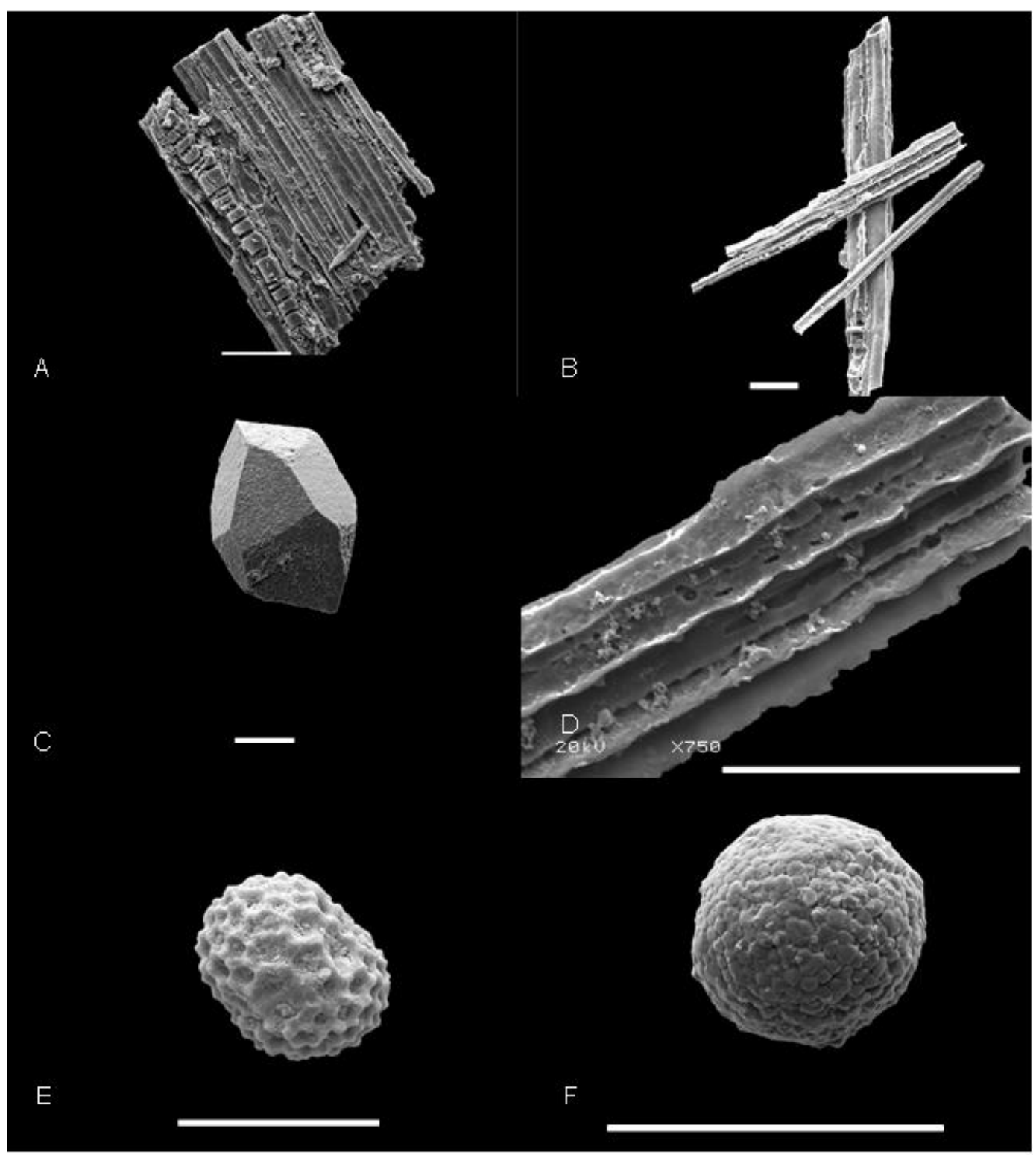


PLATE 10. Microphotographs of slides CC-15-03, CC-15-05, and CC-15-50.
A) Benthic foraminifer in sample CC-15-03 10X scale bar 100 microns.
B) Glomospira sp? Sample CC-15-05 10X scale bar 100 microns.
C) Bitumen filled vug in sample CC-15-05 10X scale bar 100 microns.
D) Unidentified fragments (roveacrinid?) in sample CC-15-05 scale bar 100 microns.
E) Bioclast (microbial accumulation?) in sample CC-15-05 scale bar 100 microns.
F) Ammonite fragment in sample CC-15-50 4X scale bar 200 microns. 


\section{PLATE 10}
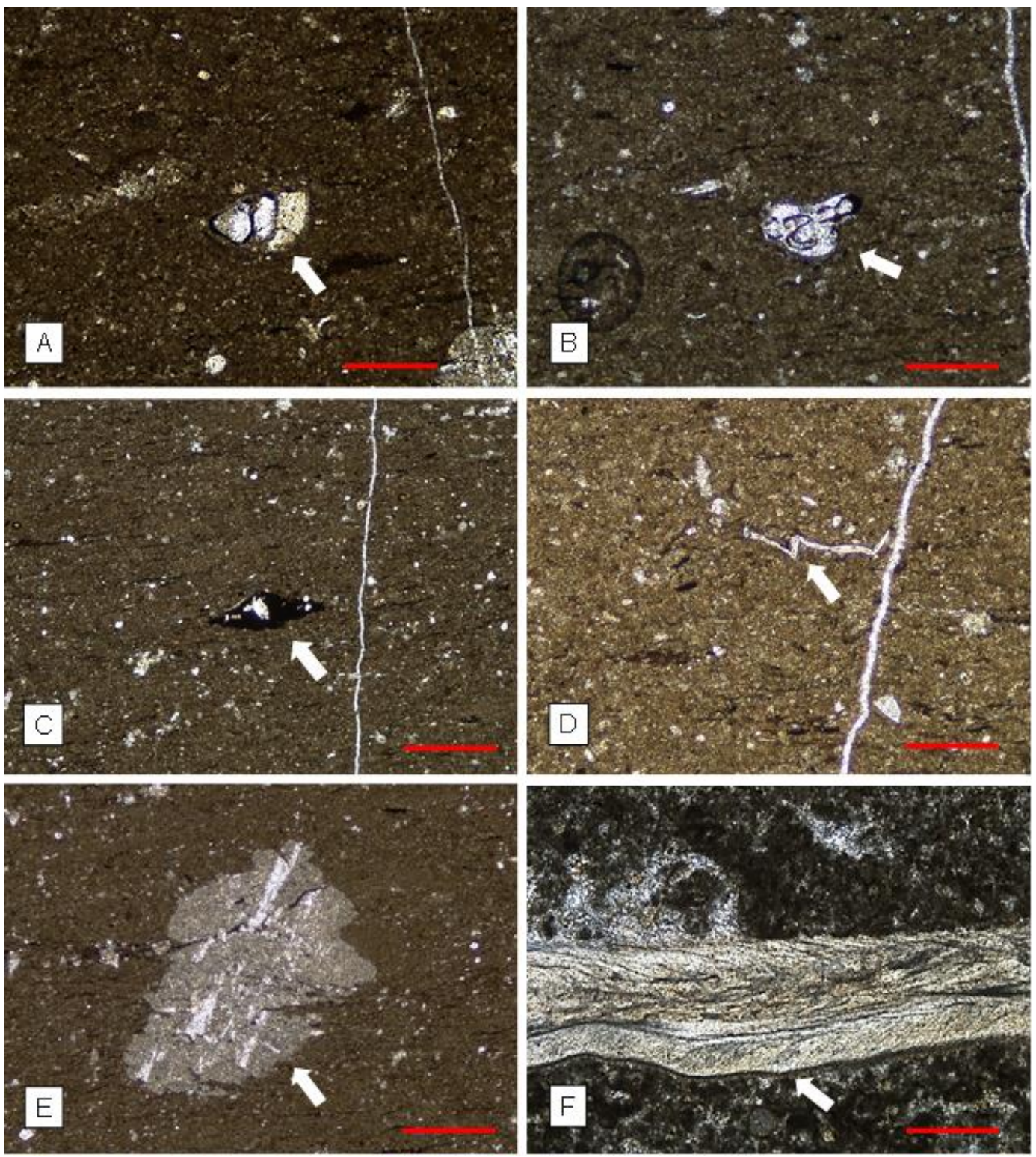


\section{APPENDICES}

APPENDIX I. Table reporting values for $\delta^{13} \mathrm{C}_{\text {org }}, \delta^{15} \mathrm{~N}_{\text {org }}$, TOC, TIC, and TC from analyzed samples of the Eastern Prada Quarry section and their corresponding stratigraphic levels.

\begin{tabular}{|c|c|c|c|c|c|c|}
\hline Sample ID & Height $(m)$ & $\delta^{13} \mathrm{C}(\%)$ & $\delta^{15} \mathrm{~N}(\%)$ & TOC (wt\%) & TIC (wt\%) & TC (\%) \\
\hline CC-15-66 & 28.11 & -24.82 & 4.46 & 0.84 & 94.27 & 95.11 \\
\hline CC-15-65 & 27.99 & -24.59 & 3.38 & 1.04 & 94.66 & 95.70 \\
\hline CC-15-64 & 27.17 & -24.45 & 5.29 & 1.04 & 93.53 & 94.56 \\
\hline CC-15-63 & 27.08 & -23.91 & 5.95 & 2.55 & 90.94 & 93.49 \\
\hline CC-15-62 & 26.42 & -24.40 & 4.88 & 0.94 & 96.12 & 97.06 \\
\hline CC-15-61 & 25.53 & -24.25 & 3.89 & 0.64 & 95.60 & 96.23 \\
\hline CC-15-60 & 24.59 & -24.35 & 5.05 & 1.04 & 99.13 & 100.17 \\
\hline CC-15-59 & 23.69 & -24.62 & 4.91 & 1.81 & 92.56 & 94.36 \\
\hline CC-15-58 & 23.29 & -25.47 & 4.34 & 1.17 & 92.21 & 93.38 \\
\hline CC-15-57 & 22.22 & -24.94 & 3.65 & 1.44 & 96.20 & 97.65 \\
\hline CC-15-56 & 21.49 & -24.51 & 4.58 & 1.00 & 95.12 & 96.12 \\
\hline CC-15-55 & 20.59 & -25.17 & 5.30 & 1.37 & 89.05 & 90.42 \\
\hline CC-15-54 & 19.82 & -25.05 & 5.00 & 1.31 & 89.86 & 91.17 \\
\hline CC-15-53 & 19.44 & -24.23 & 4.98 & 2.24 & 91.01 & 93.25 \\
\hline CC-15-52 & 19.29 & -25.35 & 5.30 & 1.54 & 93.45 & 94.99 \\
\hline CC-15-51 & 19.05 & -24.17 & 4.72 & 0.90 & 95.54 & 96.45 \\
\hline CC-15-50 & 18.68 & -24.08 & 2.30 & 0.63 & 86.60 & 87.24 \\
\hline CC-15-49 & 18.05 & -23.78 & 5.17 & 1.20 & 95.51 & 96.72 \\
\hline CC- $15-48$ & 17.98 & -23.94 & 5.54 & 2.18 & 91.87 & 94.05 \\
\hline CC-15-47 & 17.34 & -24.37 & 4.09 & 1.51 & 98.70 & 100.22 \\
\hline CC-15-46 & 16.96 & -24.57 & 1.82 & 0.67 & 90.73 & 91.40 \\
\hline CC-15-45 & 16.45 & -24.74 & 2.58 & 1.10 & 51.33 & 52.43 \\
\hline CC-15-44 & 15.90 & -24.70 & 4.11 & 1.17 & 94.40 & 95.57 \\
\hline CC-15-43 & 15.40 & -24.93 & 4.38 & 1.04 & 96.12 & 97.16 \\
\hline CC-15-42 & 14.60 & -24.68 & 4.12 & 1.04 & 95.76 & 96.80 \\
\hline CC- $15-41$ & 14.54 & -25.00 & 4.12 & 1.61 & 93.26 & 94.87 \\
\hline CC- $15-40$ & 14.36 & -25.14 & 4.26 & 1.17 & 95.40 & 96.57 \\
\hline CC-15-39 & 14.23 & -25.04 & 4.44 & 1.74 & 93.91 & 95.65 \\
\hline CC-15-38 & 14.19 & -25.22 & 3.78 & 1.77 & 94.93 & 96.70 \\
\hline CC-15-37 & 13.29 & -24.87 & 3.46 & 1.14 & 97.00 & 98.14 \\
\hline CC-15-36 & 12.54 & -24.61 & 3.42 & 1.34 & 94.83 & 96.17 \\
\hline CC-15-35 & 12.39 & -24.82 & 4.49 & 1.76 & 90.04 & 91.80 \\
\hline CC-15-34 & 12.12 & -24.75 & 4.33 & 1.30 & 89.26 & 90.56 \\
\hline CC-15-33 & 11.86 & -24.80 & 4.62 & 1.23 & 89.19 & 90.42 \\
\hline CC-15-32 & 11.76 & -24.18 & 4.53 & 1.53 & 89.07 & 90.60 \\
\hline CC-15-31 & 11.60 & -24.65 & 4.74 & 2.04 & 90.53 & 92.57 \\
\hline CC-15-30 & 11.40 & -24.18 & 4.19 & 2.24 & 90.25 & 92.48 \\
\hline CC-15-29 & 11.18 & -24.56 & 4.33 & 1.37 & 92.52 & 93.89 \\
\hline CC-15-28 & 11.01 & -24.70 & 4.95 & 1.70 & 92.42 & 94.12 \\
\hline CC-15-27 & 10.82 & -25.10 & 4.65 & 1.47 & 92.86 & 94.33 \\
\hline CC-15-26 & 10.61 & -24.92 & 4.29 & 1.17 & 92.80 & 93.97 \\
\hline CC-15-25 & 10.41 & -24.59 & 4.18 & 1.44 & 91.32 & 92.76 \\
\hline CC-15-24 & 10.22 & -24.93 & 3.24 & 1.57 & 90.11 & 91.68 \\
\hline CC-15-23 & 8.42 & -24.51 & 4.49 & 1.60 & 89.66 & 91.26 \\
\hline CC-15-22 & 6.02 & -24.95 & 3.36 & 1.90 & 86.77 & 88.67 \\
\hline CC-15-21 & 4.89 & -25.42 & 4.41 & 1.67 & 91.60 & 93.27 \\
\hline CC-15-20 & 4.16 & -26.13 & 4.82 & 2.43 & 87.27 & 89.71 \\
\hline CC-15-19 & 3.04 & -25.71 & 3.94 & 1.73 & 87.27 & 89.01 \\
\hline CC-15-18 & 2.24 & -25.69 & 4.53 & 6.66 & 53.79 & 60.45 \\
\hline CC-15-17 & 2.04 & -25.65 & 3.68 & 1.47 & 92.87 & 94.34 \\
\hline CC-15-16 & 1.84 & -25.81 & 4.71 & 2.30 & 90.76 & 93.06 \\
\hline CC-15-15 & 1.75 & -26.07 & 4.61 & 2.00 & 90.25 & 92.25 \\
\hline CC-15-14 & 1.62 & -25.88 & 3.87 & 2.21 & 90.58 & 92.79 \\
\hline CC-15-13 & 1.30 & -26.18 & 4.50 & 2.27 & 89.38 & 91.65 \\
\hline
\end{tabular}




$\begin{array}{lllllll}\text { CC-15-12 } & 1.16 & -25.76 & 4.08 & 1.84 & 90.15 & 91.99 \\ \text { CC-15-11 } & 1.10 & -26.01 & 4.09 & 1.90 & 91.82 & 93.73 \\ \text { CC-15-10 } & 0.95 & -25.95 & 3.60 & 1.30 & 93.10 & 94.40 \\ \text { CC-15-9 } & 0.83 & -25.92 & 3.75 & 1.17 & 92.61 & 93.78 \\ \text { CC-15-8 } & 0.66 & -26.24 & 4.24 & 1.86 & 91.28 & 93.14 \\ \text { CC-15-7 } & 0.56 & -26.04 & 4.20 & 2.27 & 90.98 & 93.24 \\ \text { CC-15-6 } & 0.49 & -25.66 & 3.21 & 2.50 & 89.87 & 92.37 \\ \text { CC-15-5 } & 0.42 & -25.57 & 3.73 & 2.59 & 88.33 & 90.92 \\ \text { CC-15-4 } & 0.37 & -25.72 & 4.70 & 2.40 & 89.43 & 91.83 \\ \text { CC-15-3 } & 0.28 & -25.81 & 3.06 & 2.46 & 90.10 & 92.56 \\ \text { CC-15-2 } & 0.07 & -25.80 & 4.00 & 2.47 & 89.37 & 91.83 \\ \text { CC-15-1 } & 0.04 & -25.53 & 4.62 & 3.10 & 86.12 & 89.22 \\ \text { CC-15-0 } & 0.00 & -25.51 & 5.04 & 2.24 & 89.60 & 91.85 \\ & \text { Average } & -25.04 & 4.14 & 1.69 & 90.79 & 92.48\end{array}$


APPENDIX II. Table reporting Pristane/Phytane ratios from biomarker analysis (18) samples. Pristane and Phytane determined from gas chromatograms.

\begin{tabular}{ccccc}
\hline Sample ID & Height $(\mathrm{m})$ & $\operatorname{Pr}$ & Phy & Pr/Phy \\
\hline CC-15-65 & 27.99 & 0.38 & 1.32 & 0.29 \\
CC-15-64 & 27.17 & 0.91 & 0.72 & 1.26 \\
CC-15-63 & 27.08 & 1.02 & 1.04 & 0.98 \\
CC-15-62 & 26.42 & 0.46 & 0.82 & 0.56 \\
CC-15-52 & 19.29 & 0.66 & 1.59 & 0.42 \\
CC-15-51 & 19.05 & 0.44 & 0.66 & 0.67 \\
CC-15-49 & 18.05 & 0.39 & 1.26 & 0.31 \\
CC-15-48 & 17.98 & 0.53 & 1.06 & 0.50 \\
CC-15-35 & 12.39 & 0.68 & 0.78 & 0.87 \\
CC-15-18 & 2.24 & 1.36 & 1.06 & 1.28 \\
CC-15-16 & 1.84 & 0.8 & 0.46 & 1.74 \\
CC-15-15 & 1.75 & 0.24 & 0.64 & 0.38 \\
CC-15-11 & 1.10 & 0.34 & 0.21 & 1.62 \\
CC-15-10 & 0.95 & 0.44 & 0.64 & 0.69 \\
CC-15-09 & 0.83 & 0.22 & 0.47 & 0.47 \\
CC-15-08 & 0.66 & 0.51 & 0.82 & 0.62 \\
CC-15-03 & 0.28 & 2.16 & 1.49 & 1.45 \\
CC-15-01 & 0.04 & 0.66 & 0.9 & 0.73
\end{tabular}


APPENDIX III. Table reporting values for major, biolimiting and RSTE's, Ni/Co ratios with their corresponding stratigraphic levels of the Prada Quarry section.

\begin{tabular}{|c|c|c|c|c|c|c|c|c|c|c|c|c|c|c|c|}
\hline \multicolumn{16}{|c|}{$\begin{array}{l}\text { Element } \\
\text { Concentrations } \\
\text { in (ppm) }\end{array}$} \\
\hline Sample ID & Height (m) & $\mathrm{Al}$ & $\mathrm{Si}$ & $\mathrm{P}$ & $\mathrm{Ti}$ & $\mathrm{V}$ & $\mathrm{Cr}$ & $\mathrm{Fe}$ & Co & $\mathrm{Ni}$ & $\mathrm{Cu}$ & Mo & Th & $\mathrm{U}$ & $\mathrm{Ni} / \mathrm{Co}$ \\
\hline CC-15-65 & 27.99 & 427 & 6489 & 55.8 & 19.3 & 9.2 & 15.2 & 273.5 & 1.2 & 21.9 & 1.5 & 2.2 & 0.0 & 1.2 & 18.7 \\
\hline CC-15-63 & 27.08 & 3436 & 13036 & 63.4 & 173.1 & 30.5 & 18.7 & 1881.2 & 0.5 & 27.7 & 4.5 & 7.6 & 0.4 & 5.3 & 54.2 \\
\hline CC-15-61 & 25.53 & 179 & 3493 & 23.7 & 8.7 & 3.6 & 8.9 & 148.5 & 0.8 & 12.9 & 0.9 & 1.2 & 0.0 & 0.6 & 16.4 \\
\hline CC-15-60 & 24.59 & 526 & 4743 & 31.4 & 20.5 & 7.9 & 8.2 & 215.5 & 0.8 & 4.8 & 0.8 & 0.6 & 0.0 & 1.2 & 6.0 \\
\hline CC-15-58 & 23.29 & 439 & 9160 & 41.1 & 20.5 & 6.0 & 10.4 & 258.3 & 2.2 & 8.4 & 1.2 & 0.6 & 0.1 & 0.9 & 3.7 \\
\hline CC-15-57 & 22.22 & 204 & 1857 & 31.7 & 16.9 & 5.2 & 8.9 & 202.9 & 0.7 & 9.6 & 1.4 & 0.9 & 0.0 & 1.1 & 12.9 \\
\hline CC-15-56 & 21.49 & 567 & 8519 & 48.9 & 24.7 & 5.0 & 11.1 & 267.6 & 1.5 & 10.4 & 0.9 & 0.9 & 0.1 & 0.7 & 7.1 \\
\hline CC-15-52 & 19.29 & 2258 & 9924 & 77.6 & 94.1 & 19.8 & 11.9 & 948.0 & 1.3 & 9.7 & 1.8 & 2.4 & 0.2 & 1.5 & 7.4 \\
\hline CC-15-51 & 19.05 & 578 & 6103 & 33.0 & 19.2 & 12.5 & 10.9 & 256.2 & 1.6 & 10.0 & 0.9 & 1.5 & 0.0 & 1.3 & 6.3 \\
\hline CC-15-48 & 17.98 & 1891 & 7734 & 53.1 & 97.8 & 20.6 & 14.3 & 1234.3 & 1.5 & 15.9 & 3.8 & 5.7 & 0.3 & 4.5 & 10.9 \\
\hline CC-15-47 & 17.34 & 292 & 4168 & 26.7 & 13.5 & 5.2 & 8.8 & 224.1 & 0.7 & 8.0 & 0.9 & 1.4 & 0.0 & 0.9 & 10.8 \\
\hline CC-15-46 & 16.96 & 344 & 3233 & 31.6 & 11.8 & 14.2 & 11.2 & 151.1 & 1.7 & 13.0 & 0.7 & 1.4 & 0.0 & 1.8 & 7.7 \\
\hline CC-15-45 & 16.45 & 293 & 156805 & 22.8 & 17.7 & 3.7 & 90.5 & 369.5 & 9.0 & 163.9 & 6.1 & 8.4 & 0.0 & 0.6 & 18.3 \\
\hline CC-15-43 & 15.40 & 304 & 17388 & 16.5 & 17.0 & 3.1 & 5.1 & 260.3 & 1.6 & 7.8 & 1.1 & 2.2 & 0.0 & 0.8 & 4.9 \\
\hline CC-15-40 & 14.36 & 491 & 4677 & 49.3 & 22.2 & 9.4 & 9.7 & 306.8 & 2.3 & 4.9 & 5.3 & 0.5 & 0.1 & 1.5 & 2.1 \\
\hline CC-15-37 & 13.28 & 187 & 1600 & 31.3 & 9.8 & 5.7 & 9.1 & 238.2 & 0.7 & 5.0 & 0.7 & 0.7 & 0.0 & 0.9 & 7.2 \\
\hline CC-15-35 & 12.38 & 2637 & 16216 & 105.8 & 131.9 & 21.5 & 17.7 & 1490.2 & 1.5 & 17.6 & 3.8 & 2.8 & 0.4 & 2.8 & 11.8 \\
\hline CC-15-29 & 11.17 & 989 & 6784 & 56.4 & 46.8 & 15.5 & 13.4 & 575.8 & 4.4 & 28.7 & 2.0 & 6.7 & 0.1 & 1.5 & 6.5 \\
\hline CC-15-24 & 10.21 & 1198 & 14230 & 58.5 & 58.8 & 6.2 & 18.6 & 747.5 & 0.8 & 25.4 & 1.9 & 2.3 & 0.2 & 0.7 & 30.8 \\
\hline CC-15-23 & 8.41 & 1400 & 13417 & 60.8 & 69.0 & 6.3 & 13.8 & 779.8 & 0.5 & 32.0 & 2.2 & 3.2 & 0.2 & 0.8 & 63.9 \\
\hline CC-15-22 & 6.01 & 1805 & 19730 & 71.0 & 89.7 & 11.0 & 14.7 & 1130.5 & 0.8 & 30.5 & 2.6 & 4.1 & 0.3 & 1.5 & 38.4 \\
\hline CC-15-21 & 4.88 & 1753 & 9994 & 76.6 & 75.1 & 7.8 & 12.5 & 945.9 & 0.4 & 22.7 & 2.2 & 3.3 & 0.2 & 1.0 & 52.4 \\
\hline CC-15-20 & 4.16 & 5142 & 21451 & 78.4 & 238.8 & 18.9 & 21.3 & 1995.8 & 0.6 & 38.6 & 3.5 & 8.6 & 0.5 & 2.4 & 63.0 \\
\hline CC-15-19 & 3.03 & 3375 & 12703 & 122.5 & 159.7 & 16.5 & 14.1 & 2054.8 & 0.6 & 29.6 & 5.8 & 26.5 & 0.5 & 1.8 & 47.7 \\
\hline CC-15-18 & 2.65 & 57512 & 126366 & 114.1 & 2561.3 & 87.1 & 71.5 & 26652.2 & 1.1 & 61.2 & 21.4 & 14.5 & 4.6 & 2.3 & 56.4 \\
\hline CC-15-18-A & 2.24 & 38554 & 83476 & 94.5 & 2015.2 & 69.1 & 56.6 & 21940.2 & 0.8 & 49.3 & 18.0 & 13.0 & 4.6 & 2.5 & 58.5 \\
\hline CC-15-15 & 1.74 & 4580 & 18769 & 79.0 & 217.4 & 17.6 & 16.4 & 1886.7 & 0.7 & 24.8 & 3.2 & 6.3 & 0.5 & 1.9 & 36.0 \\
\hline CC-15-12 & 1.16 & 3890 & 18869 & 90.5 & 184.7 & 14.1 & 14.7 & 2409.0 & 3.2 & 22.3 & 3.9 & 5.0 & 0.5 & 1.3 & 6.9 \\
\hline CC-15-10 & 0.95 & 2081 & 12512 & 104.0 & 90.4 & 8.6 & 12.8 & 1317.1 & 0.5 & 20.3 & 2.5 & 7.1 & 0.3 & 0.7 & 39.4 \\
\hline CC-15-8 & 0.66 & 2786 & 10150 & 176.0 & 126.1 & 14.8 & 11.1 & 1806.7 & 0.7 & 14.5 & 3.0 & 10.9 & 0.4 & 2.3 & 20.9 \\
\hline CC-15-4 & 0.36 & 5255 & 20815 & 195.0 & 245.5 & 31.0 & 18.4 & 2722.2 & 10.9 & 30.0 & 8.1 & 11.4 & 0.6 & 2.3 & 2.7 \\
\hline & Average & 4689.4 & 21432.6 & 68.4 & 222.5 & 16.4 & 18.7 & 2441.6 & 1.8 & 25.2 & 3.8 & 5.3 & 0.5 & 1.6 & 23.5 \\
\hline
\end{tabular}


APPENDIX IV. Gas chromatographs for 28 samples from the Prada Quarry Section (n-alkanes).

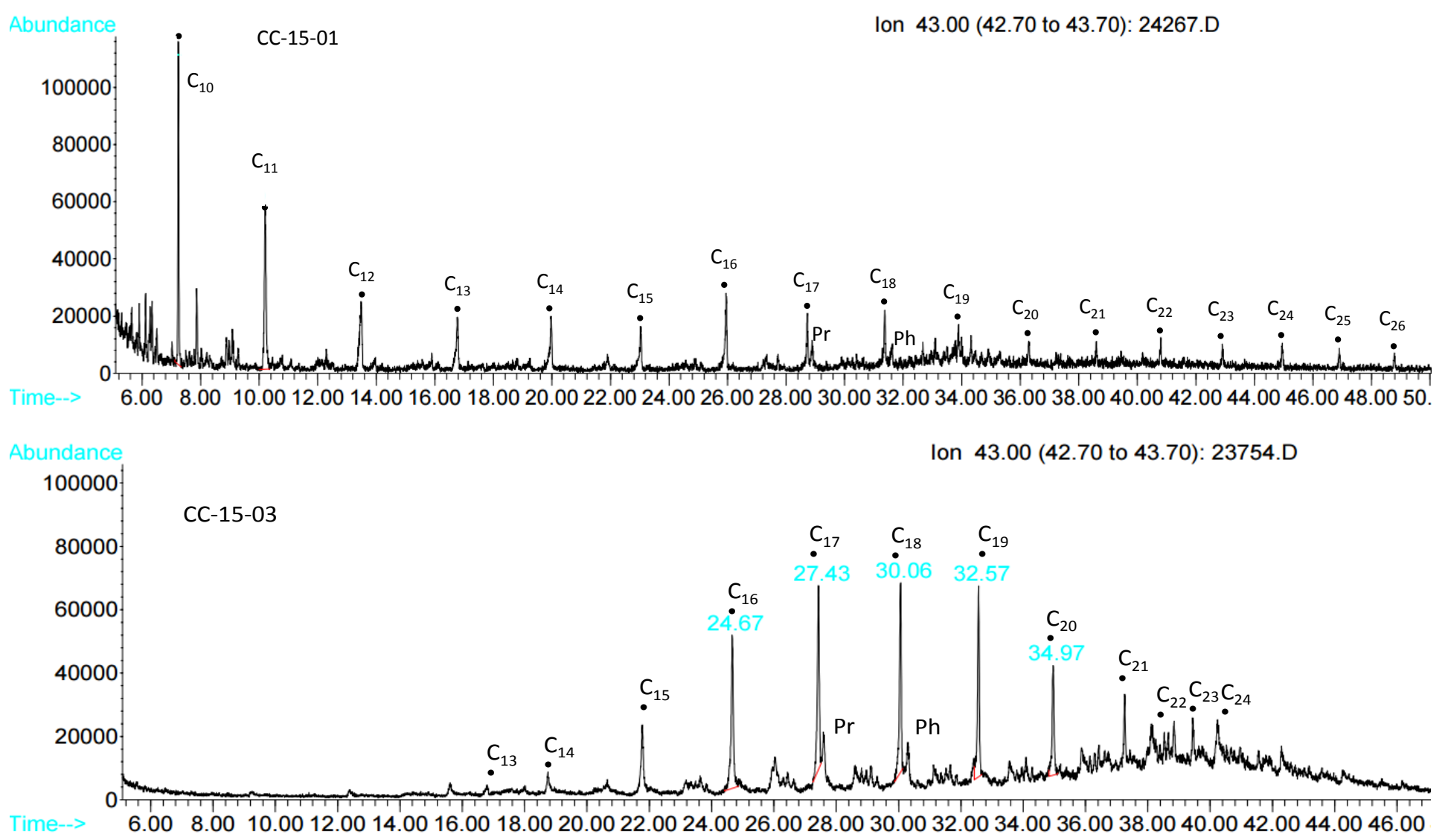



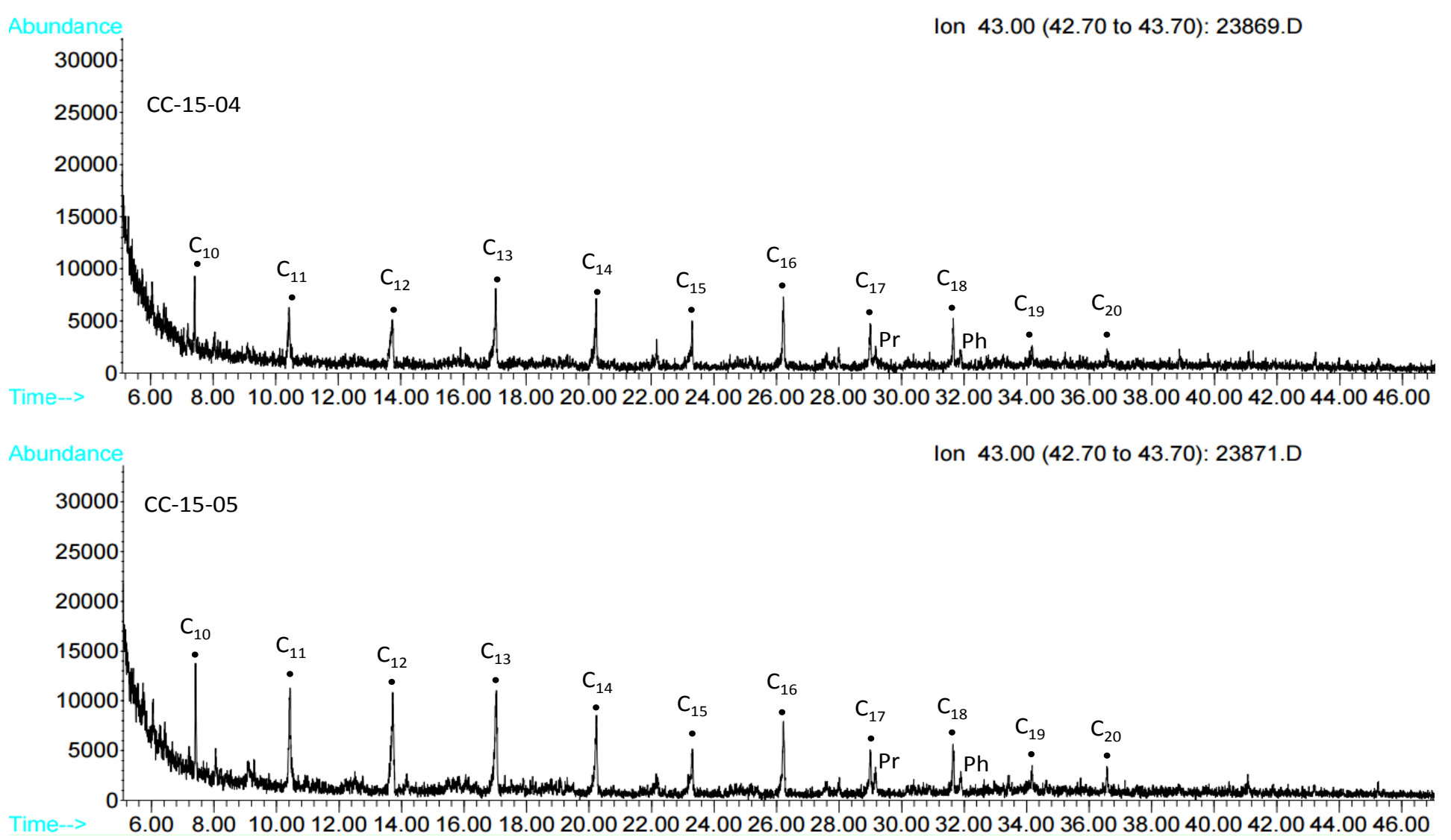


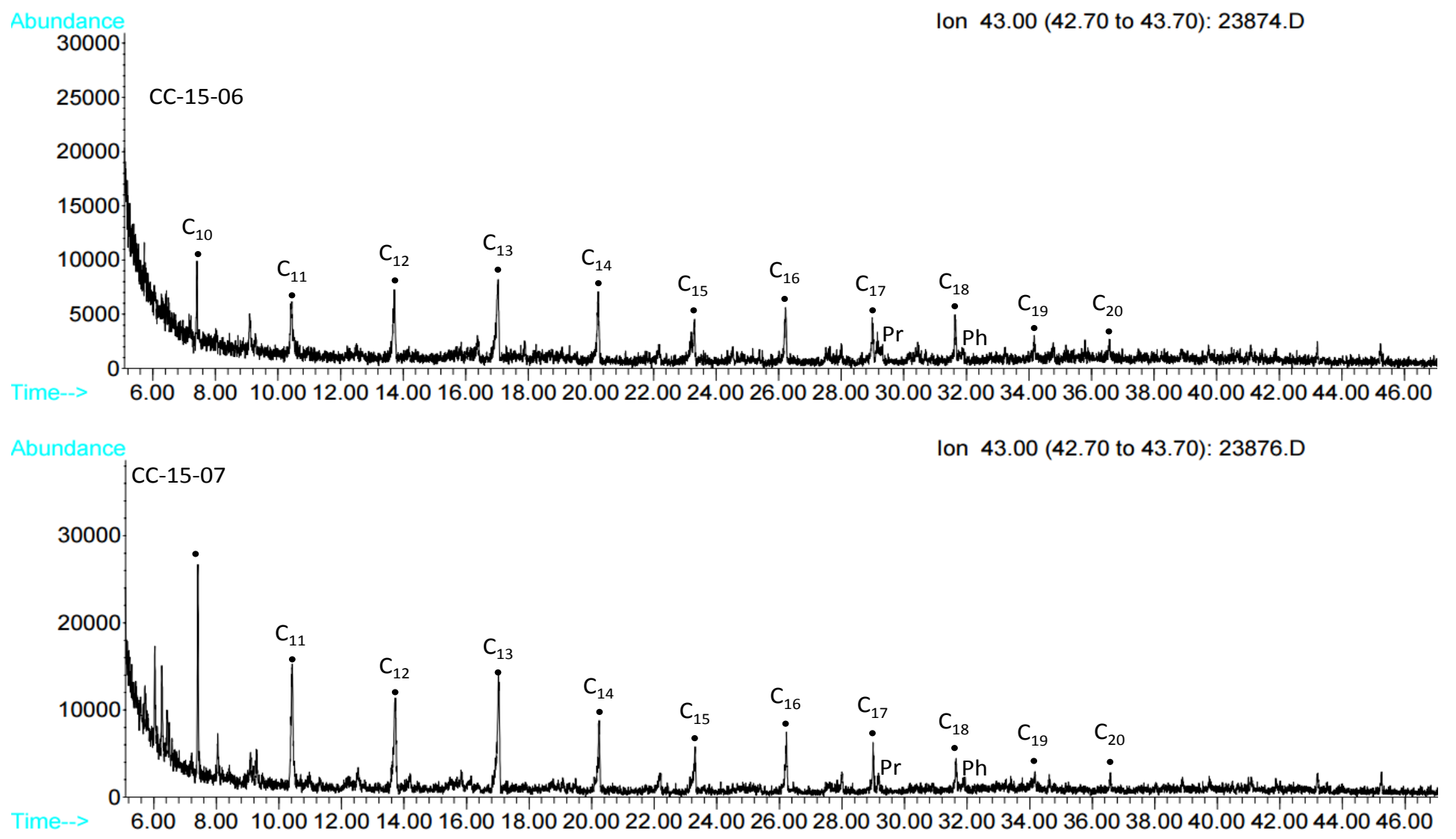




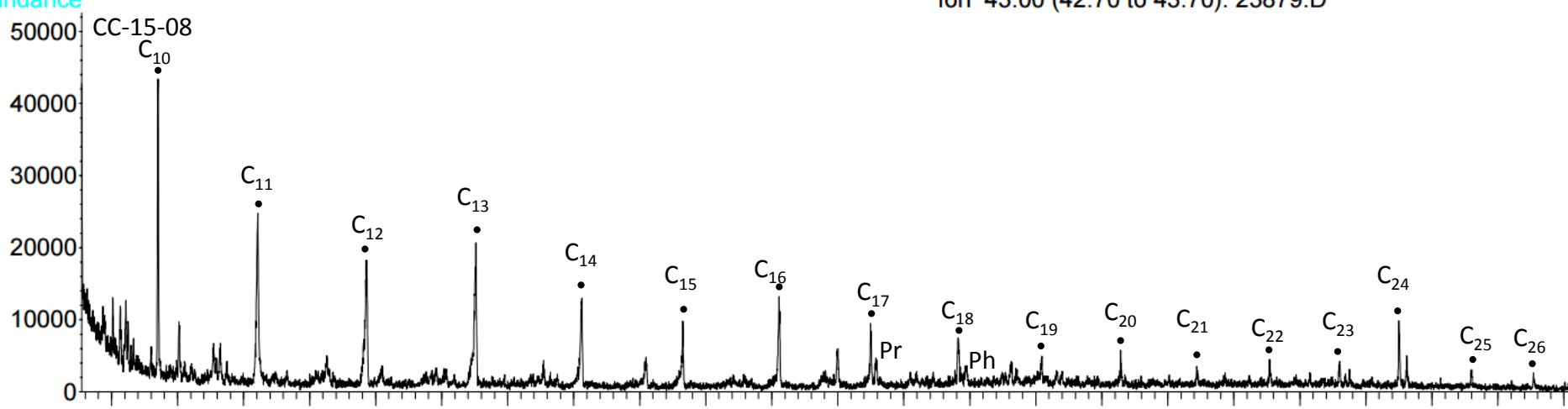

6.008 .0010 .0012 .0014 .0016 .0018 .0020 .0022 .0024 .0026 .0028 .0030 .0032 .0034 .0036 .0038 .0040 .0042 .0044 .0046 .0048 .0050$.

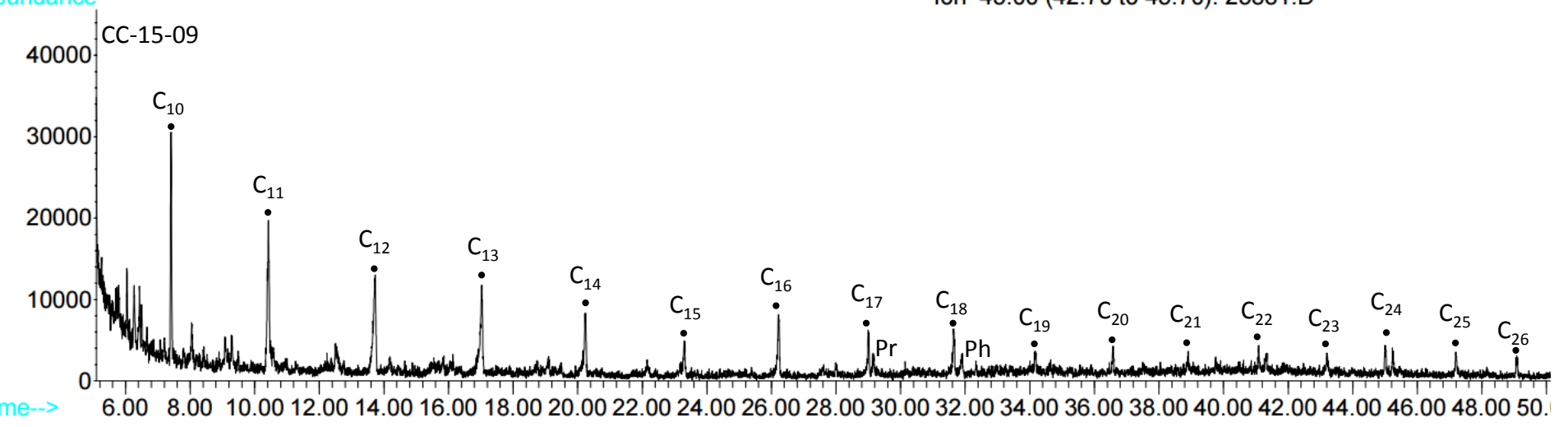



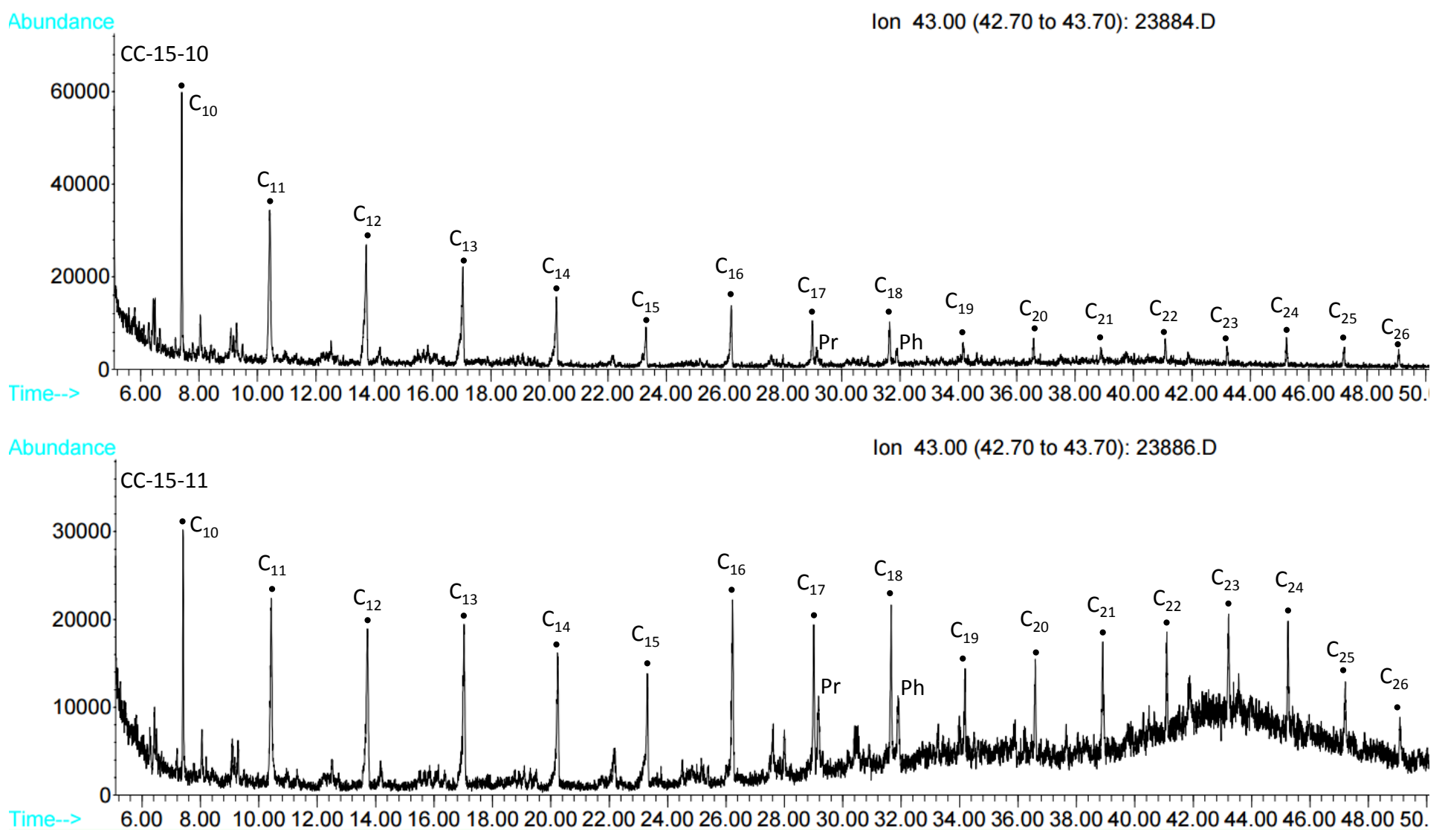
50000 CC-15-12

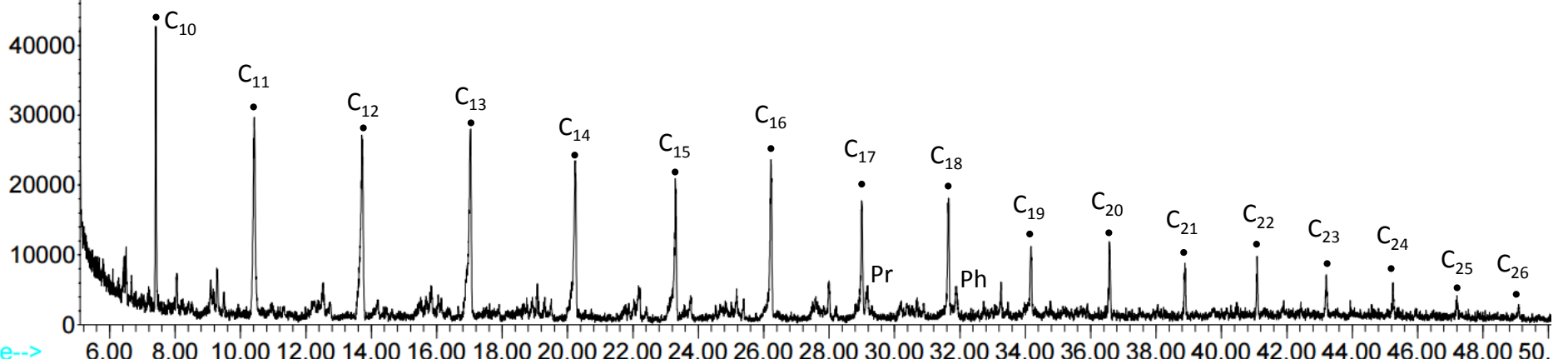

6.008 .0010 .0012 .0014 .0016 .0018 .0020 .0022 .0024 .0026 .0028 .0030 .0032 .0034 .0036 .0038 .0040 .0042 .0044 .0046 .0048 .0050

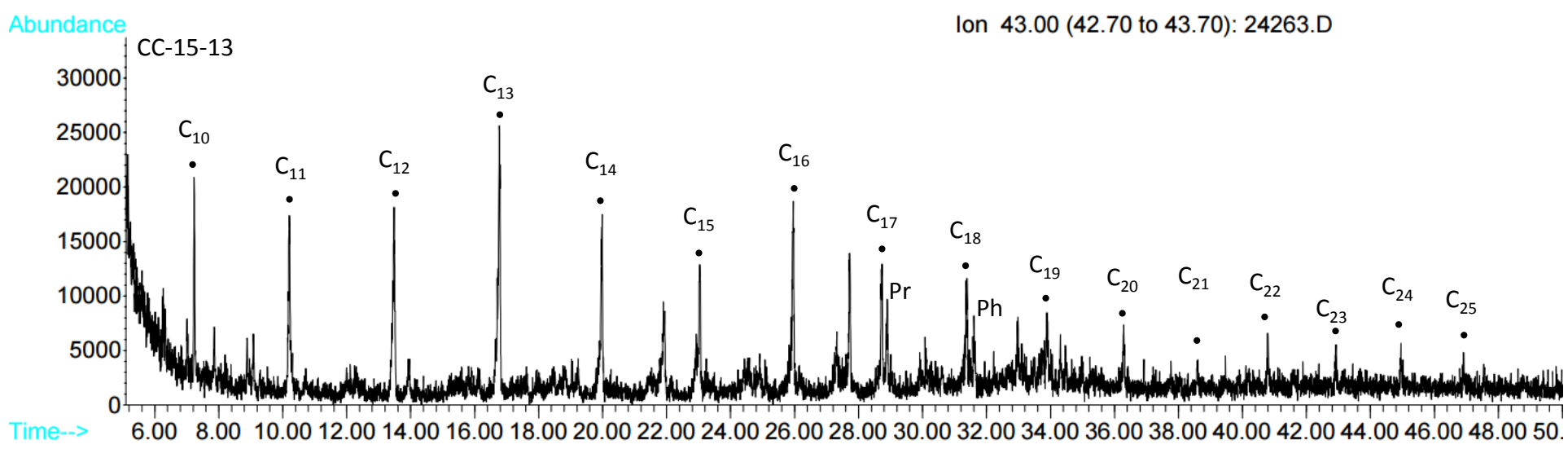



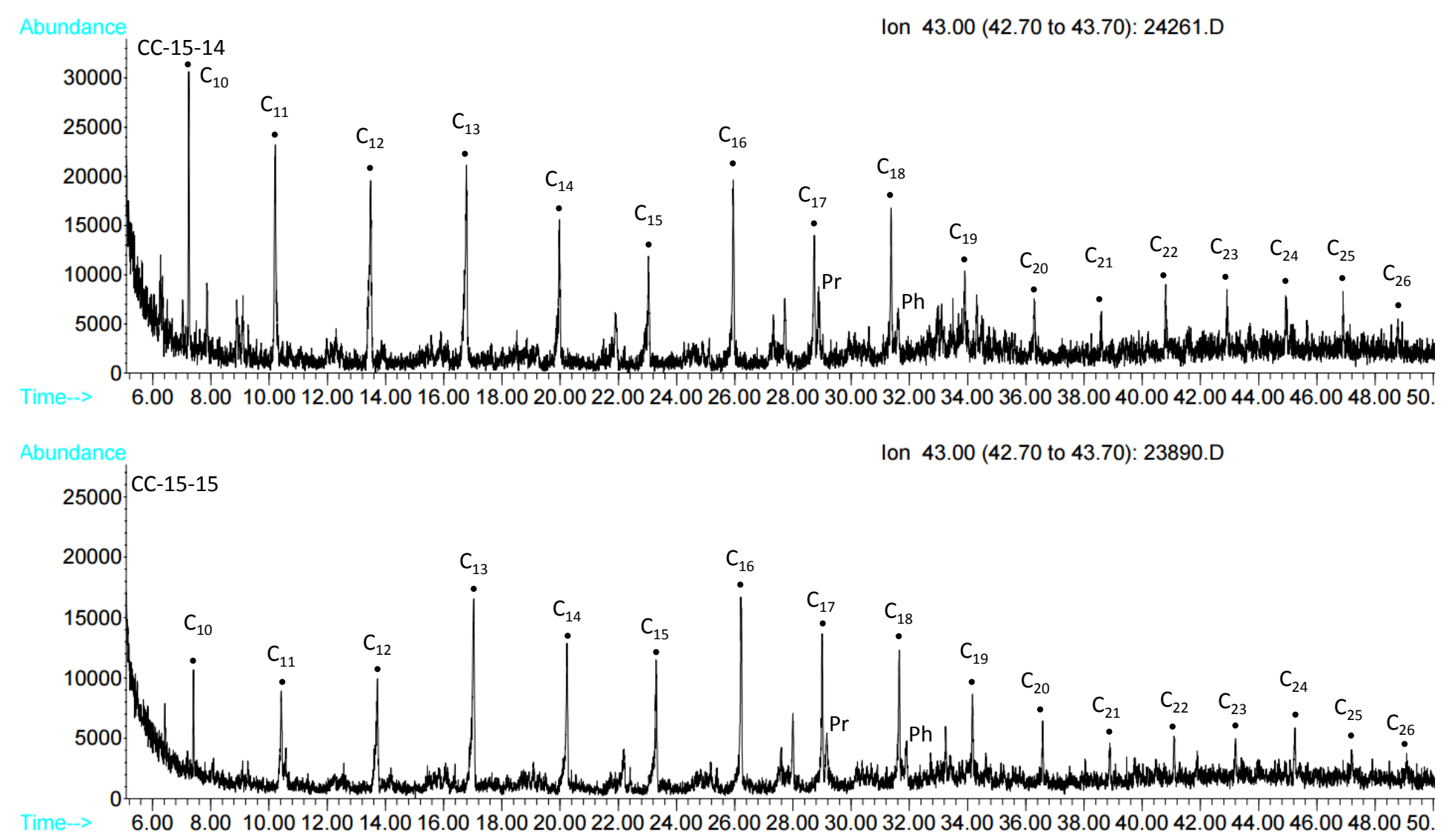

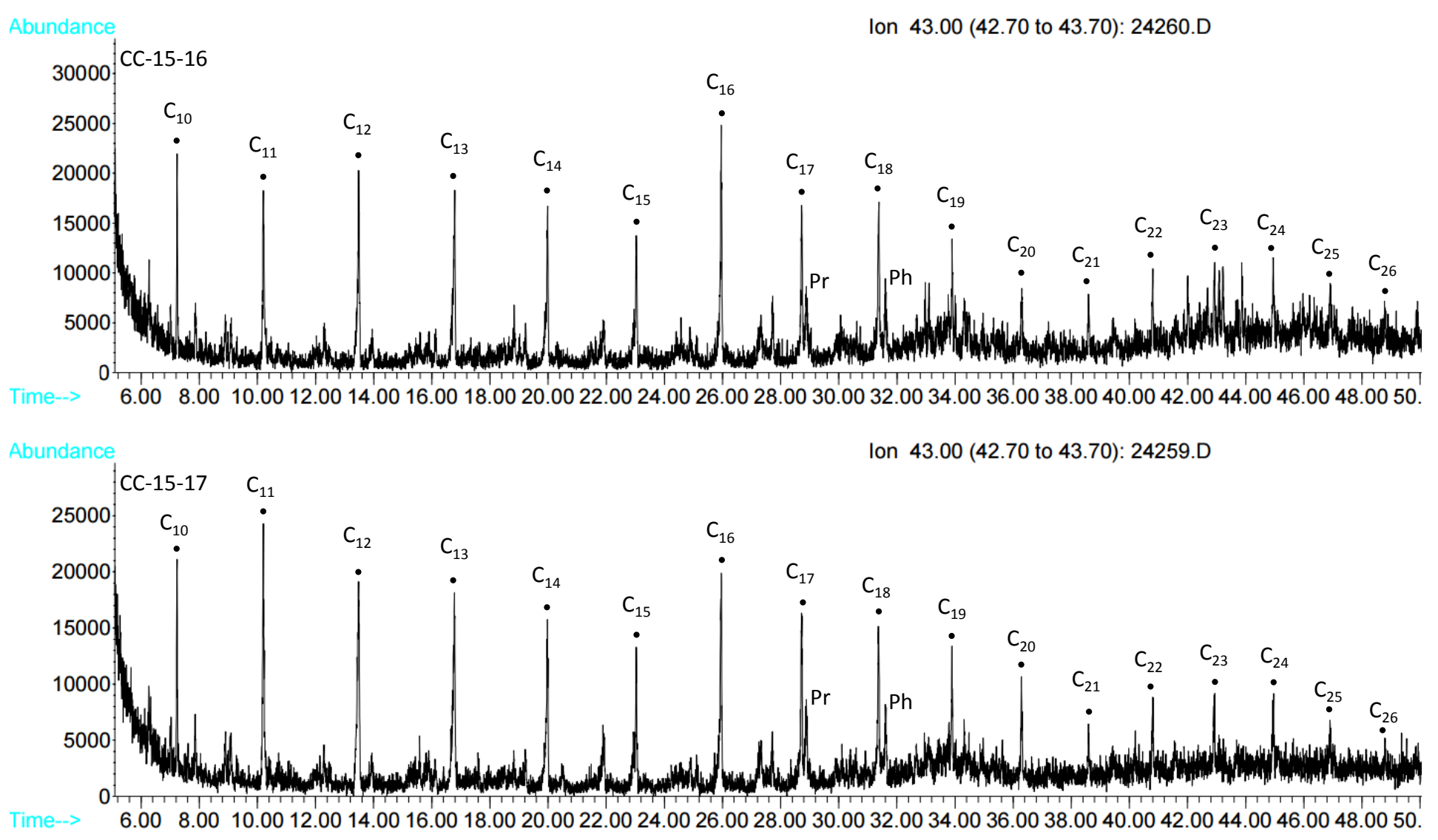

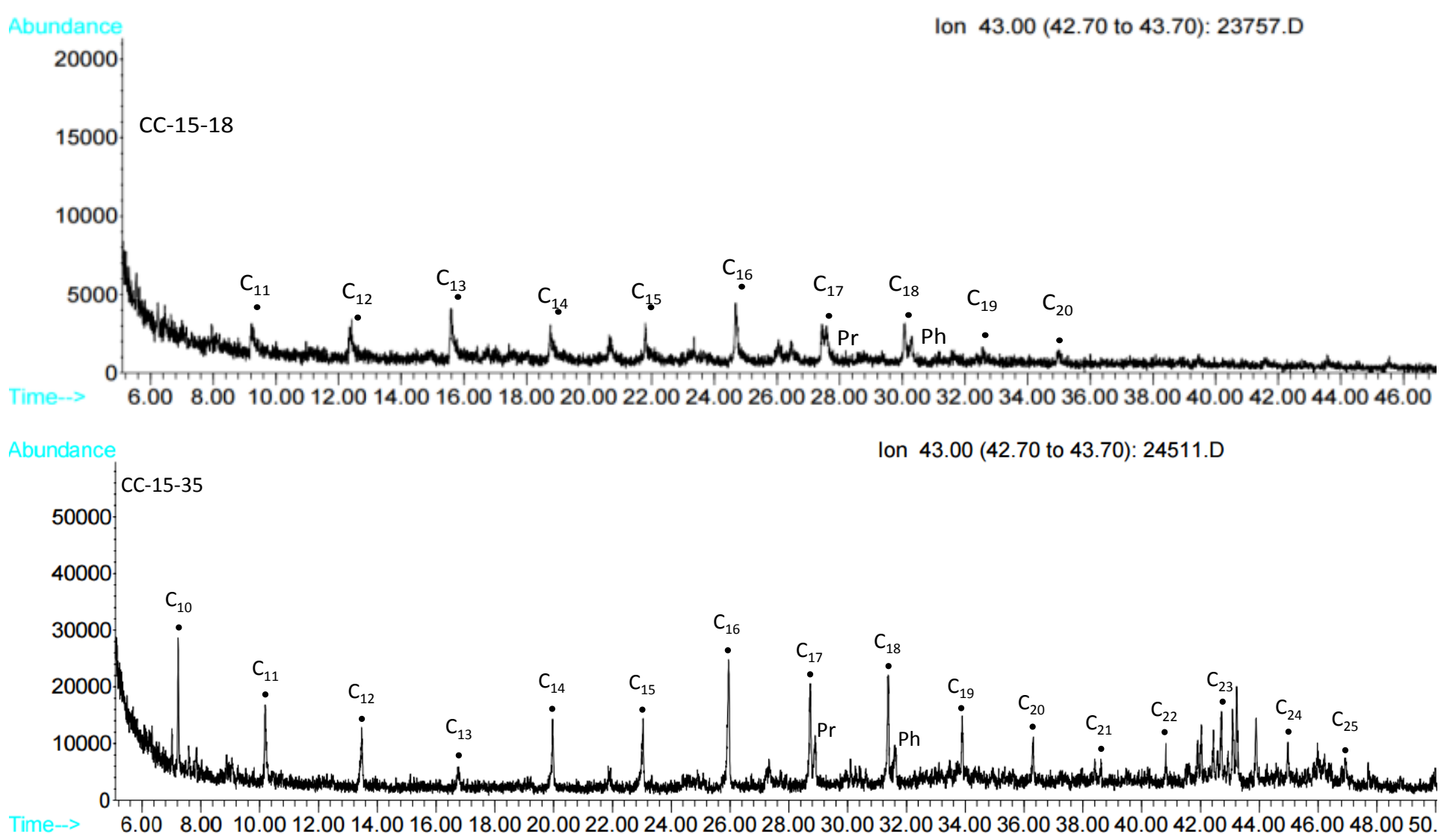

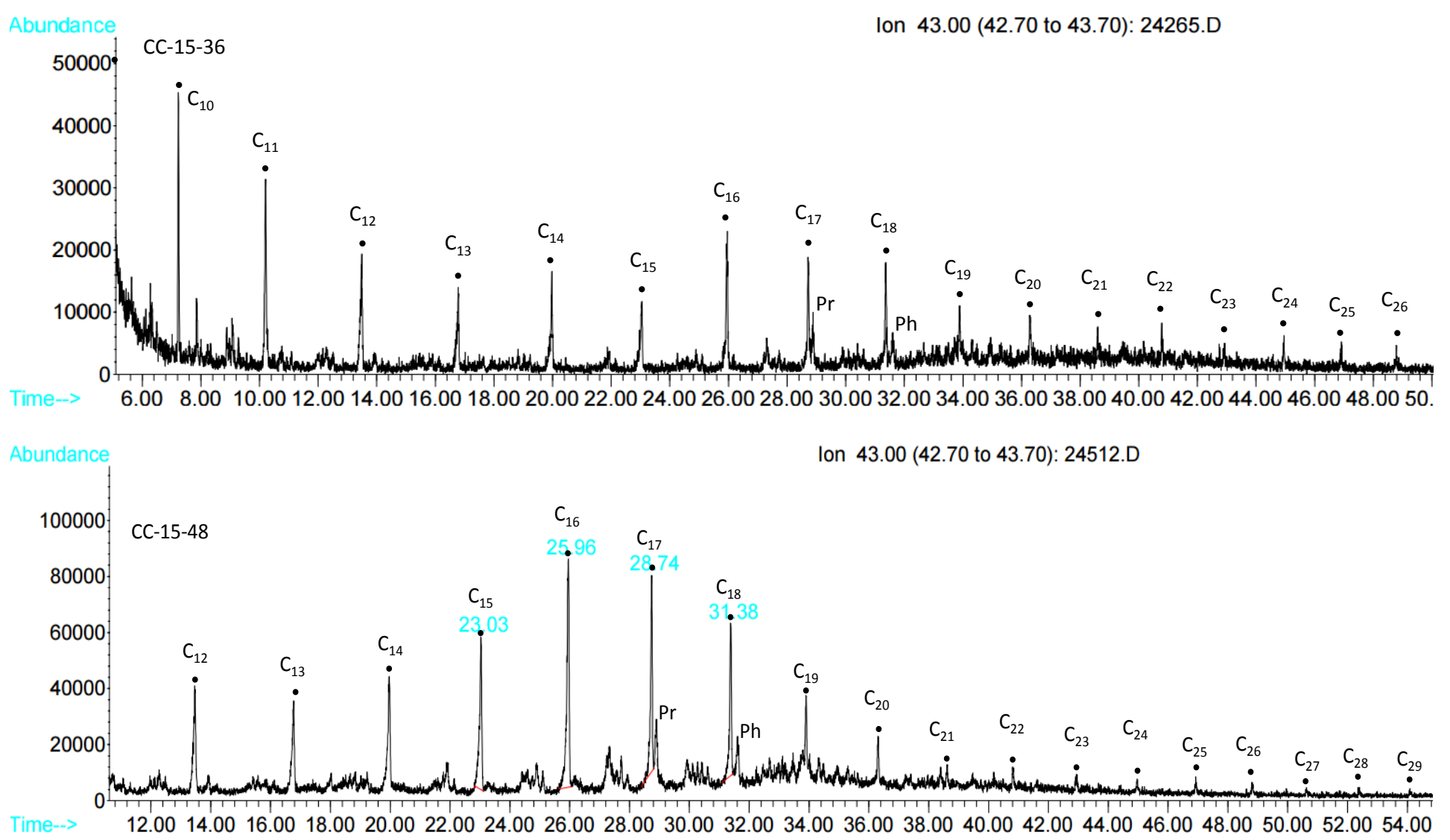


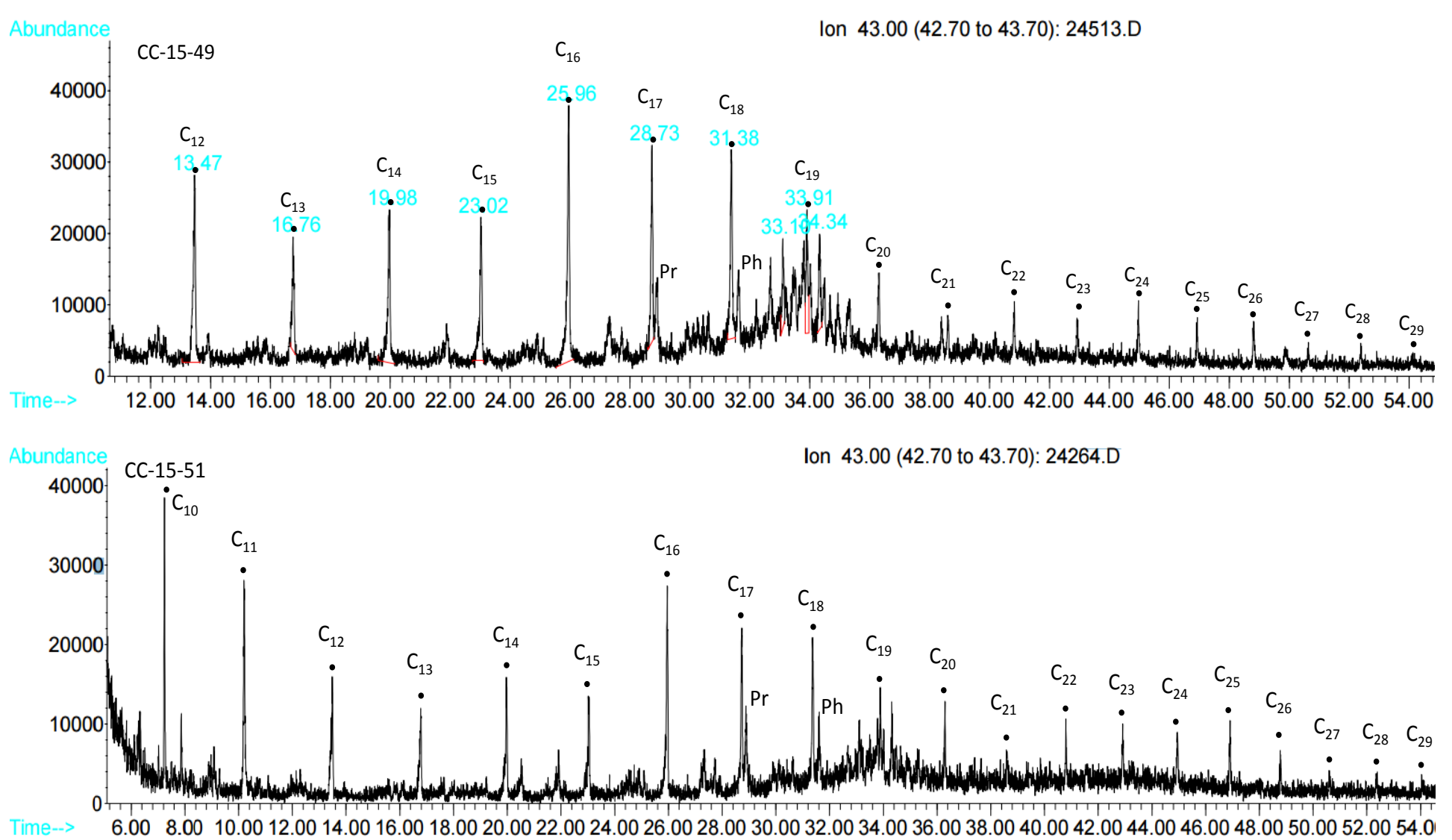




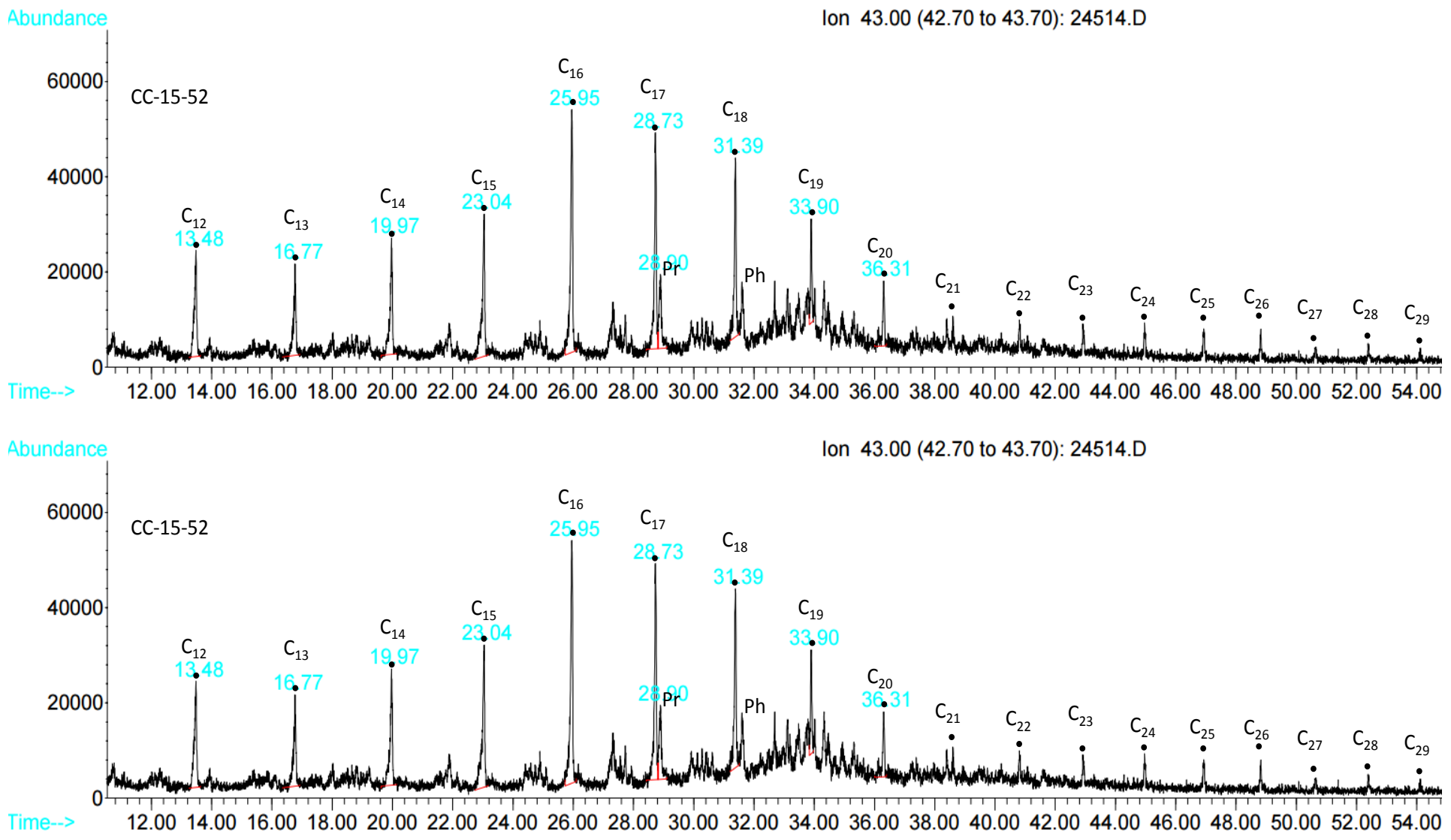

88 


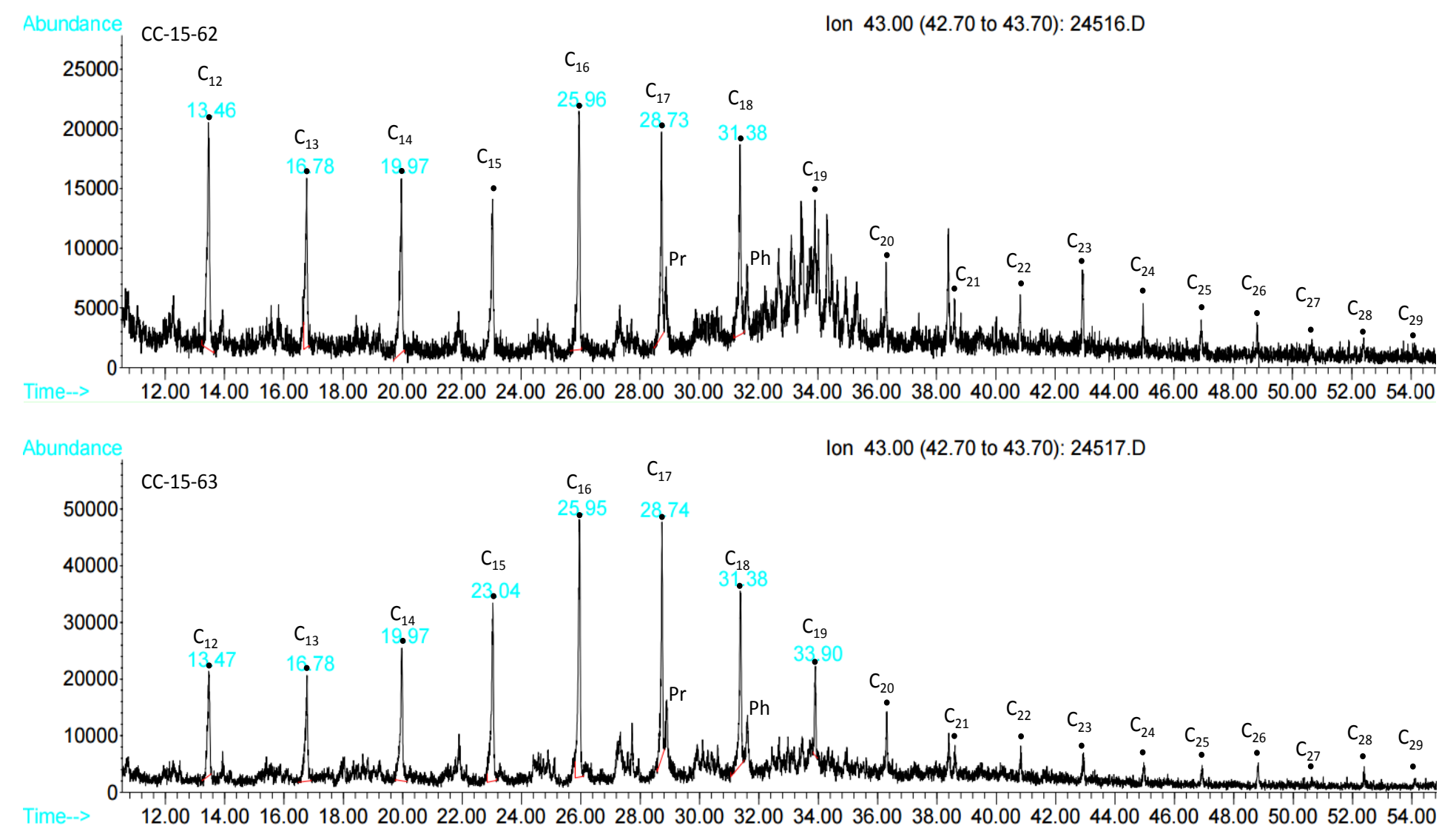




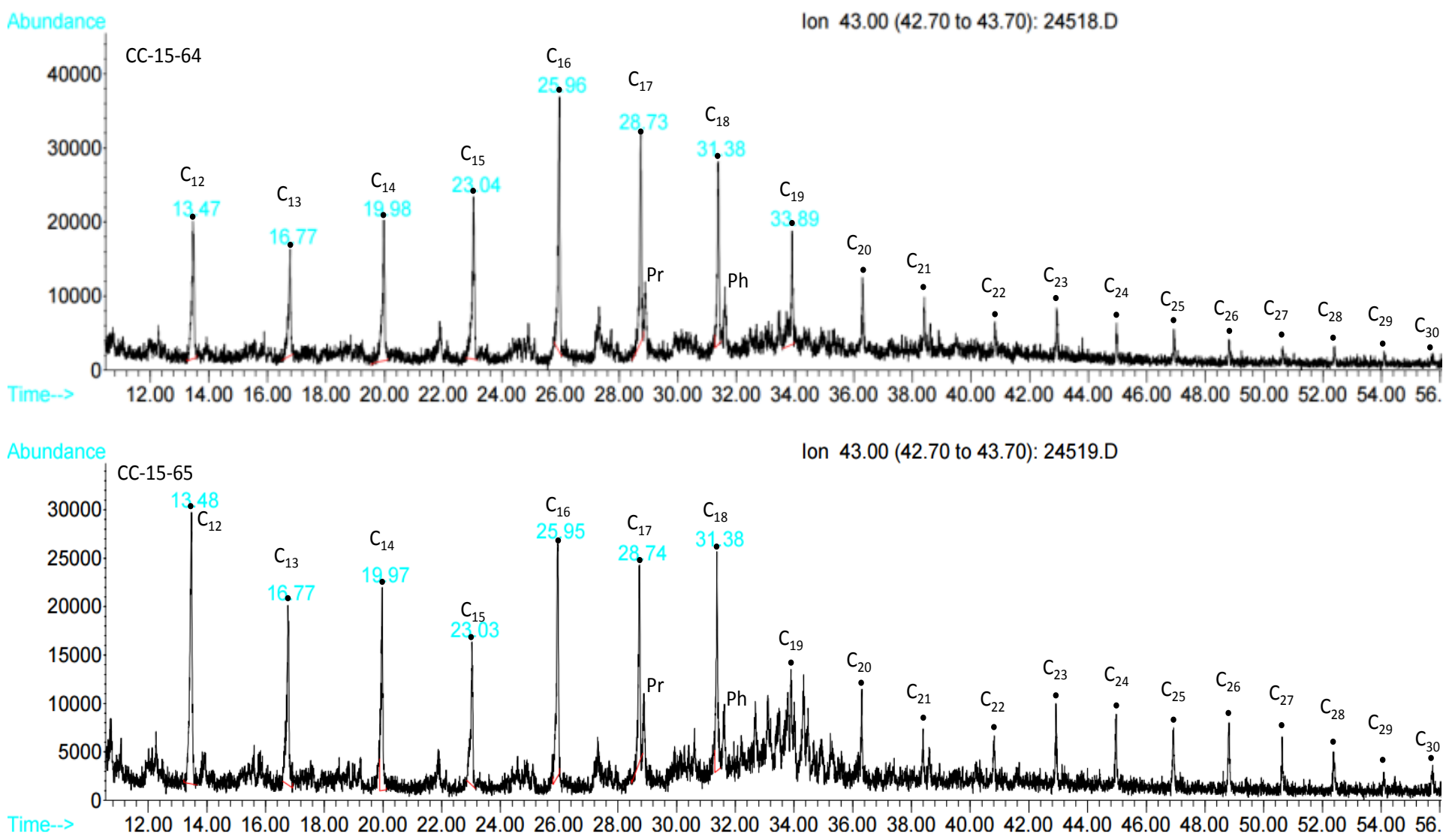

90 